\title{
Folk knowledge of invertebrates in Central Europe - folk taxonomy, nomenclature, medicinal and other uses, folklore, and nature conservation
}

\author{
Viktor Ulicsni ${ }^{1 *}$, Ingvar Svanberg ${ }^{2}$ and Zsolt Molnár ${ }^{3}$
}

\begin{abstract}
Background: There is scarce information about European folk knowledge of wild invertebrate fauna. We have documented such folk knowledge in three regions, in Romania, Slovakia and Croatia. We provide a list of folk taxa, and discuss folk biological classification and nomenclature, salient features, uses, related proverbs and sayings, and conservation.

Methods: We collected data among Hungarian-speaking people practising small-scale, traditional agriculture. We studied "all" invertebrate species (species groups) potentially occurring in the vicinity of the settlements. We used photos, held semi-structured interviews, and conducted picture sorting.

Results: We documented 208 invertebrate folk taxa. Many species were known which have, to our knowledge, no economic significance. $36 \%$ of the species were known to at least half of the informants. Knowledge reliability was high, although informants were sometimes prone to exaggeration. $93 \%$ of folk taxa had their own individual names, and $90 \%$ of the taxa were embedded in the folk taxonomy.

Twenty four species were of direct use to humans (4 medicinal, 5 consumed, 11 as bait, 2 as playthings). Completely new was the discovery that the honey stomachs of black-coloured carpenter bees (Xylocopa violacea, X. valga) were consumed. 30 taxa were associated with a proverb or used for weather forecasting, or predicting harvests. Conscious ideas about conserving invertebrates only occurred with a few taxa, but informants would generally refrain from harming firebugs (Pyrrhocoris apterus), field crickets (Gryllus campestris) and most butterflies. We did not find any mythical creatures among invertebrate folk taxa. Almost every invertebrate species was regarded as basically harmful. Where possible, they were destroyed or at least regarded as worth eradicating. However, we could find no evidence to suggest any invertebrate species had suffered population loss as a result of conscious destruction. Sometimes knowledge pertaining to the taxa could have more general relevance, and be regarded as folk wisdom concerning the functioning of nature as a whole.
\end{abstract}

Conclusions: The high number of known invertebrate folk taxa suggests that it would be worth conducting further investigations in other areas of Europe.

Keywords: Ethnozoology, Europe, Invertebrate fauna, Ethnomedicine, Nature protection, Edible insects

\footnotetext{
* Correspondence: Ulicsni.Viktor@stud.u-szeged.hu

'Department of Ecology, Faculty of Science and Informatics of the University

of Szeged, Közép fasor 52, 6726 Szeged, Hungary

Full list of author information is available at the end of the article
} 


\section{Background}

Traditional knowledge systems about the landscape and the biota have been fundamental for human development since the times of pre-modern and pre-industrial societies in Europe. Humans living in close contact with the landscape as herdsmen and peasants have long possessed unified, systematic knowledge, including folk taxonomies, about phenomena that were of importance to them. The use and management of natural resources was based on centuries-old, often millennia-old ecological experience, on multi-generational knowledge passed down from generation to generation $[1,2]$.

Ethnozoology is the scientific study of the dynamic relationships among people, and animals. Traditional ethnozoological knowledge has great cultural and economical importance. It is widely studied in the tropics and North America (e.g. [3-5]), but also in Europe (e.g. [6, 7]). Wild animal-based natural resources are often among the key resources local communities depend on $[8,9]$. A major goal of these communities is to use and manage these resources sustainably (e.g. taboos: [10]; social rules: [11, 12]). Long-term sustainability in the use and management of natural resources requires healthy ecosystems, while at the same time, sustainable management often contributes to maintaining the health of ecosystems $[13,14]$.

The knowledge passed by local traditional communities, however, not only serves sustainable use and maintenance of the local community and its environment but may also provide valuable data, information and knowledge to science and conservation. Among the potential benefits of traditional ecological knowledge, it can help science to recognize new species (e.g. [15]), provide data on population sizes and dynamics of species that are difficult to observe $[16,17]$, support the monitoring of ecosystem health, incl. pasture conditions [18, 19], and develop efficient conservation managament strategies and practices [20-23].

There is no reason to imagine that European peasant and herder communities differ fundamentally from native societies in other parts of the world with regard to their ecological knowledge [24]. However, there is scarce information about European folk knowledge of wild invertebrate fauna, including their use in healing and nutrition. Researchers in ethnobiology seldom pay attention to invertebrates in the European context [25]. By contrast, several comprehensive studies have been conducted in other parts of the world. As early as 1887, Stearns published an ethnoconchological work on the use of shells as money among aboriginals of North America [26]. This was actually the first time the prefix "ethno-" was combined with a research field, thus preceding Harshberger's term "ethnobotany", coined in 1895 [27]. Another pioneering study was Henderson's and Harrington's ethnozoology of the Tewa people in
New Mexico. This study gives a full list of animals, including invertebrates, by order and gives their Tewa names as well as their scientific names [28]. In a comprehensive study Bodenheimer [29] reviewed the ethnographical literature of the use of insects as food worldwide. Nowadays there are several important studies available dealing with ethnobiological aspects of invertebrates. We can, for instance, mention Bentley and Rodríguez [30] on the entire invertebrate fauna of Honduras, and Krause et al. [31] on the insect fauna knowledge of the Roviana people (Solomon Islands). Gurung [32] detailed the knowledge of arthropods among Tharu farmers in Nepal, while Hemp [33] described what the peoples living near Mount Kilimanjaro (Tanzania) knew about invertebrates. A particularly impressive ethnozoological study is Morris [34], dealing with the impact of insects and their classification in Malawi folk culture. In addition, the literature on aquatic and coastal-marine invertebrates is particularly rich (e.g. [35-37]).

The general experience is that many invertebrate species have specific and relevant benefits or detriments, although the number of locally known folk taxa is higher than this [31]. Some culturally salient invertebrate species may even be important keystone species in the lives of certain communities. The majority of these are coastal-marine invertebrates (e.g. shellfish in British Columbia - [37]; crabs (Ucides cordatus) in Brazil - [38, 39]). There are fewer culturally salient species among terrestrial invertebrates, and relatively few species have known folk uses (cf. [32, 40]). Keystone species include, among spiders for example, the bird-eating spiders for Afro-Brazilians in Bahia [41], while among lepidopterans there is the Brahmaeid moth on Taiwan [42].

European folk knowledge about invertebrates has, since the nineteenth century, been researched mostly by folklorists and linguists. In 1879-80 the Swedish author Strindberg used a questionnaire to gather valuable data regarding folk names and rhymes connected with the ladybird. His research, using mapping as a method, is a pioneering work in folklore about animals [43]. An encyclopedia was published about Romanian insect folklore, including local names, legends, fables and myths, the role of insects in witchcraft, and beliefs about insects as pests or as omens [44]. Herman published the local names of insects and invertebrate pest species known by Hungarian herders [45]. We can also mention an interesting article on folk knowledge about botflies (Oestridae) found as parasites on domesticated reindeer, published by the ethnographer and linguist Wiklund [46]. This kind of ethnographic folklore-linguistic research tradition continues today in Europe. Wiggen, for instance, inspired by current ethnobiologists, has recently published an exciting 
study on the traditional names of lower animals in Norway [47]. In European cultures, it is generally quite uncommon to use or consume invertebrates [48, 49]. The only invertebrates with any significant ethnobiological literature are for the taxa of snails [50], slugs [51], leeches [52], ladybirds [6], crustaceans [53], oil beetles [54] and head lice [55], but none of these are cultural keystone species. Here we should also mention a small but intriguing study on Sami children's knowledge and use of small invertebrates for amusement and to play with [56]. In 2006, Svanberg [57] published a small book with ethnozoological studies on the human relationship with bumblebees, earthworms, froghoppers, isopods, liver flukes, moonjellies and starfish in Scandinavia and Estonia. There is of course extensive biological literature on pests, but very little detailed documentation of folk knowledge has yet been carried out in Europe [58, 59]. We are, however, of the opinion that further data may exist in local languages, in works on ethnography, local history and perhaps even linguistics, but these have not yet entered the international ethnobiological literature (e.g. [60]).

There is also very little Hungarian literature on folk knowledge of invertebrates. Linguistic (dialectic), ethnographic and ethnobiological literature is available concerning 161 invertebrate species in the Sóvidék region in Transylvania [61], 67 taxa along the Danube [62], the beetle taxa Melolontha melolontha, Lucanus cervus and Lytta vesicatoria [63], and the snail species Helix spp. [64]. Sporadic data may also appear in ethnographic and linguistic literature written in the Hungarian language, for example in monographs on farming and forest ethnography, e.g. in Hegyi [65] on Lytta vesicatoria and Melolantha melolantha. To date, nothing has been published in English about the folk knowledge of invertebrates of the Carpathian Basin.

Our article has the objective of presenting the Hungarian folk knowledge of invertebrate species uncovered in three areas of the Carpathian Basin (in Romania, Slovakia, and Croatia), including:

1) a list of folk taxa of invertebrates,

2) their folk biological classifications and nomenclatures,

3) their salient features, and

4) their uses, related proverbs and sayings, and their conservation.

This is the first article in Europe to deal comprehensively with an entire invertebrate fauna. The folk knowledge, nomenclature and uses of 208 taxa are presented in detail. The high number of known folk taxa suggests that it would be worth conducting further investigations in other areas of Europe.

\section{Methods}

\section{Study areas}

We collected data among ethnic Hungarians practising small-scale, traditional agriculture. Our research was conducted in Romania (Sălaj county [Szilágyság], Nușfalău [Szilágynagyfalu] commune), Slovakia (Gemer [Gömör] region, primarily in the municipalities of Vyšné Valice [Felsővály] and Gemerské Michalovce [Gömörmihályfalva]), and Croatia (Baranja region [Drávaszög], mainly around the villages of Lug [Laskó], Vardarac [Várdaróc] and Kopačevo [Kopács] (Fig. 1)). As the people we studied spend a lot of time in the fields and forests during their everyday activities, they still have a close, direct connection to their natural environment. The settlements where the data were collected, each with between 100 and 2500 inhabitants, are characterised by a large amount of abandoned agricultural land, and by ageing populations.

The three study areas are characterised by a moderate continental climate, with a mean annual precipitation of $600-700 \mathrm{~mm}$. The mean annual temperature in the two northern areas is $8-8.5{ }^{\circ} \mathrm{C}$ (July mean $19{ }^{\circ} \mathrm{C}$, January mean $-4{ }^{\circ} \mathrm{C}$ ), while in Baranja, further south, it is slightly higher, around $10{ }^{\circ} \mathrm{C}$ (July mean $21{ }^{\circ} \mathrm{C}$, January mean $-4{ }^{\circ} \mathrm{C}$ ) [66]. The elevation is $75-$ 90 m.a.s.l. in Baranja, 200-350 m.a.s.l. in Sălaj, and 190-500 m.a.s.l. in Gemer. Gemer and Sălaj typically have closed broadleaved forests (oak), while in Baranja there is a mixture of riparian vegetation, marshland and mixed hardwood gallery forests (oak, ash and elm).

\section{Data collection and analysis}

Data was collected in Sălaj in summer 2010, and in Baranja and Gemer in summer 2012. In each area, the objective was to identify and interview local people with the most extensive knowledge. We employed a number of techniques: in Sălaj we first consulted the local Calvinist priest, and then followed the snowball method; in Gemer we also followed the snowball method, but this time starting with the best informants from earlier ethnobotanical researches; in Baranja we collaborated with the local nature conservation warden, István Tórizs, to meet the people who, in the warden's view, had the greatest traditional folk knowledge. In total we interviewed 58 people. The overall average age of the interviewees was 75 years (within a range from 36 to 90 years), and the regional average ages were 78 in Sălaj, 74 in Baranja, and 71 in Gemer. All the informants retained memories of traditional forest use and smallholder farming, and some were still practitioners. 55 of the interviewees were Calvinist.

We conducted indoor interviews recorded on a dictaphone (approximately $88 \mathrm{~h}$ of recording), since the presentation of living specimens and direct observation of animals in the wild would have been greatly inconvenient for most of the informants. Prior informed consent was 


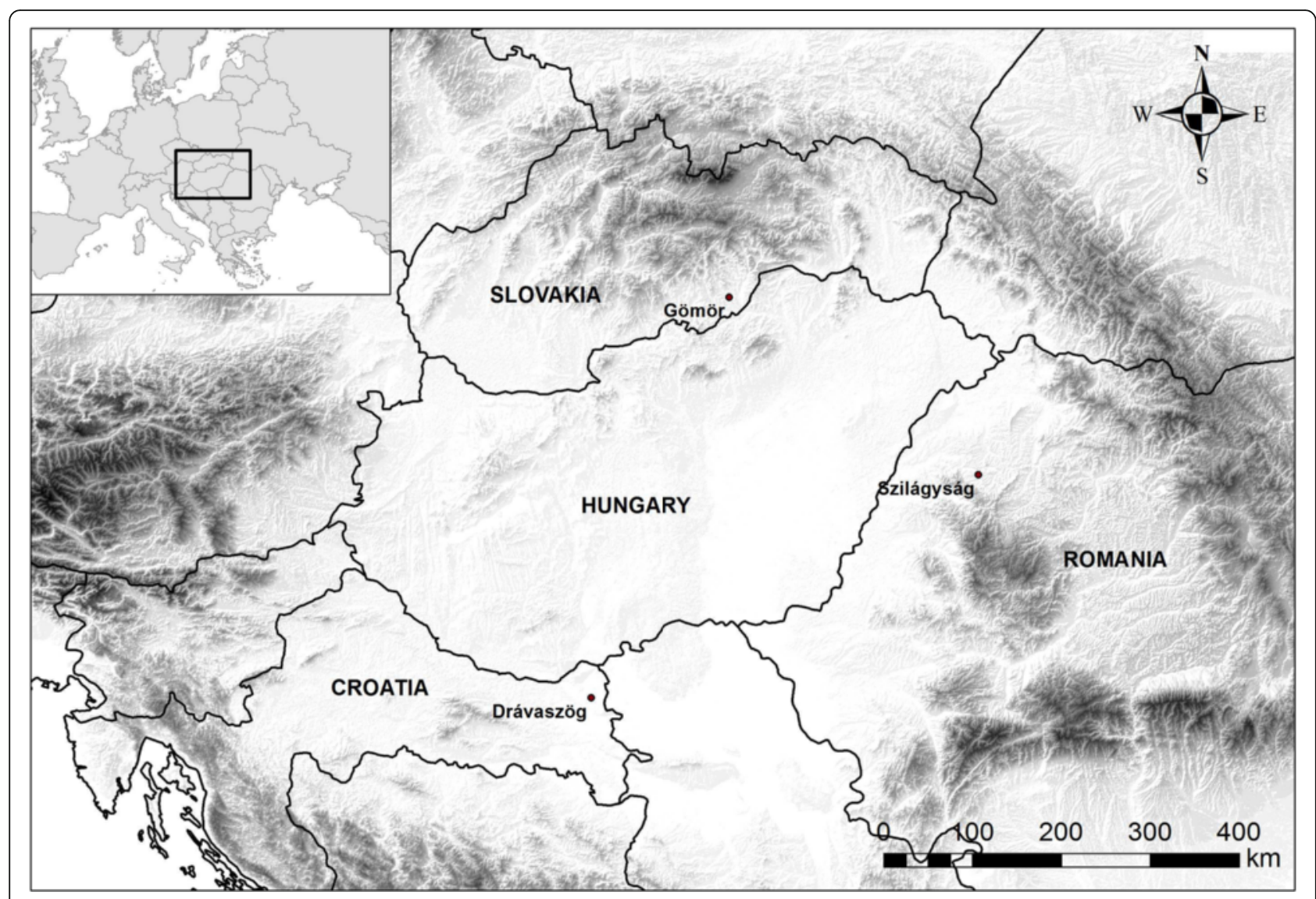

Fig. 1 The study areas in Central Europe

obtained before all the interviews, and ethical guidelines suggested by the International Society of Ethnobiology were followed. We studied "all" invertebrate species or species groups potentially occurring in the vicinity of the settlements under investigation. We placed an average of 12 photos of species of similar habitat and size on a sheet of A4 paper, to give interviewees a sense of the context and relative size of each taxon. In many instances during our preliminary study, the differing scale of the pictures had greatly inhibited recognition. Where ambiguous descriptions occurred, further enquiries of the characteristics of the species in question were made in order to facilitate identification of the animal at the finest possible taxonomic level. Detailed lists of invertebrate taxa documented by zoologists were available for the regions studied or for ecologically similar neighbouring regions (e.g. [67-70]). We also included a few species that do not occur in the areas under investigation, in order to check the authenticity of local folk knowledge.

In total we collected 3465 individual data records on 208 folk generics and specifics. We also conducted semistructured interviews with the majority of informants and carried out picture sorting, during which they were asked to group species according to their own systems. We used these results to reconstruct the folk taxonomy. Figures depicting taxonomic relations were prepared following the method used by Berlin [71]. Circles drawn in solid lines on these figures indicate scientific taxa (one species, one genus, one order, one family), whereas those drawn in small and large dashes represent, respectively, folk taxa and more inclusive folk categories. When circles of scientific taxa overlap, this indicates that certain scientific taxa were viewed as alike (e.g. "it is a house mouse, but of a different kind"). Inclusive categories were established on the basis of data collected by pile sorting, co-references and direct questions. However, it was not our intention to arrange individual taxa according to Berlin's system of taxonomic levels, since the communities we examined are too heterogeneous for this. For each of the taxa, where possible, we documented the local name (or names), their salient features, their uses, any damage they cause, any personal attitudes expressed towards the taxa (positive, negative or neutral), and related folklore issues. The habitats of the species (see Appendix) were determined based on the interviews, on our own experiences and on the scientific literature.

We have listed our data in tables, and summarised the results broken down according to informant and taxon. We have not carried out a quantitative comparison of the 


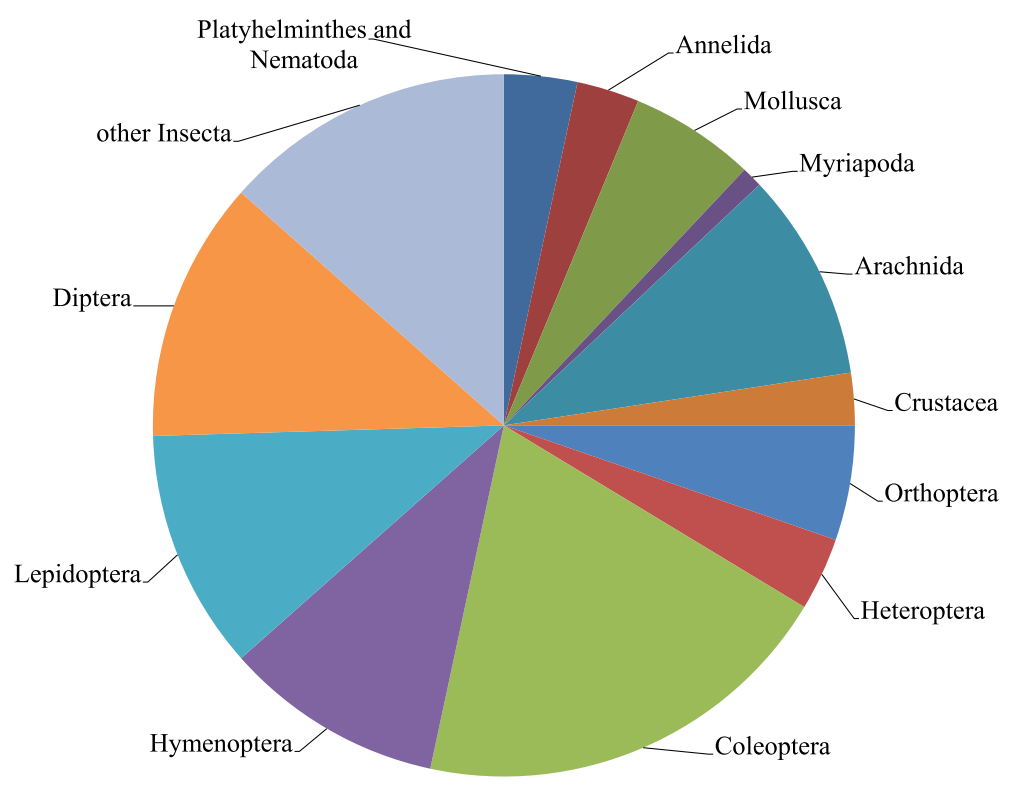

Fig. 2 The taxonomic structure of the 208 Hungarian folk taxa of invertebrates documented among ethnic Hungarians in Sălaj, Gemer and Baranja

knowledge among the three communities, for the data sets have, in many cases, low sample sizes. The differences between the three areas which are important from a qualitative aspect are presented in the chapter on results and discussion. Literal quotations are in italics, and comments by individual interviewees are separated by a slash.

\section{Results and discussion}

Folk taxa and unknown taxa

The folk knowledge of invertebrates revealed in the areas under investigation was extensive and detailed. Folk generics and specifics were documented for a total of 208 invertebrate folk taxa. The majority of these were Coleoptera,

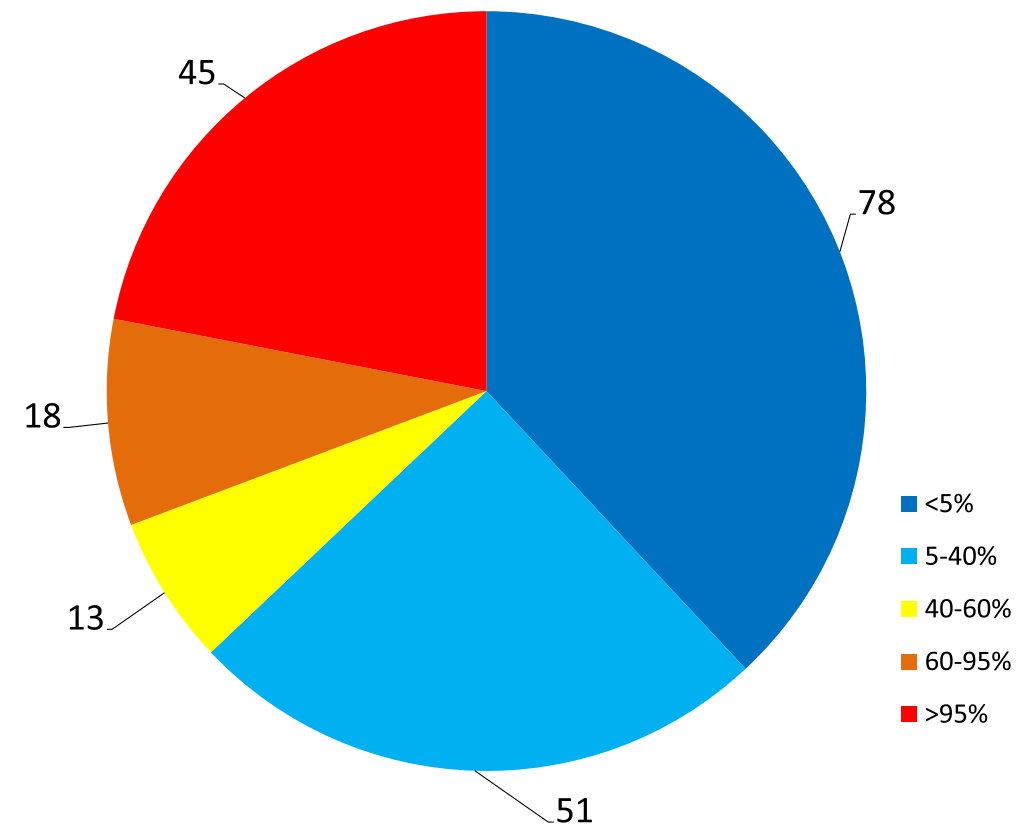

Fig. 3 Proportions of species known by different numbers of informants: known by very few (1-3) informant(s) $(<5 \%)$; known by $3-23$ informants (5-40\%); known by 24-35 informants (40-60\%); known by 36-55 informants (60-95\%); known by "everybody" (56-58 informants) (>95\%) 
Diptera, Lepidoptera, Arachnida and Hymenoptera, while Myriapoda, Crustacea and Annelida were represented with fewer folk taxa (Fig. 2).

Of the 208 folk taxa, in 135 cases (65\%) they could be identified with one or two scientific species, in 28 cases (13\%) with several (3-6) scientific species, and in 45 cases (22\%) with many (more than 6) scientific species.

Certain species were exceptionally well known, but $37.5 \%$ of the taxa were familiar only to between 1 and 3 people (Fig. 3). With certain species or groups of species, the only informants who knew them were those most likely to encounter them because of their profession or as a result of some special activity (such as fishermen using animals as bait, or herders with livestock parasites). 45 taxa (22\%) were known to almost all the informants.

The 208 folk generics and specifics found is greater than the number of known vertebrate folk taxa ([72], Ulicsni ined). Compared with four studies that covered entire faunas $[28,30,33,73]$, the ratio of invertebrate to vertebrate taxa in our region was significant $(54 \%$ of specific level taxa). Apart from a single exception (bivalves-frogs, see below), the invertebrates were classified into separate supraspecific groups from the vertebrates, although invertebrates did not constitute a unified group, i.e., an inclusive folk taxon with clearly defined boundaries. This distinction is much sharper, for example, among Mongolians [74].

The differences in the fauna of the three different areas seemed to have little effect on the list of local folk taxa. The faunas of the three areas are similar, as they all contain mostly common, generalist species. The proportion of folk taxa that were restricted to just one of the three areas amounted to only $3.8 \%$ (8 species). For this reason, our analyses treated all the data uniformly. Based on our data, the folk taxonomies could also be regarded - with negligible differences - as uniform (major differences are shown in the results and discussed below).

The distribution of knowledge was not even. Only $36 \%$ of the species were known to at least half of the

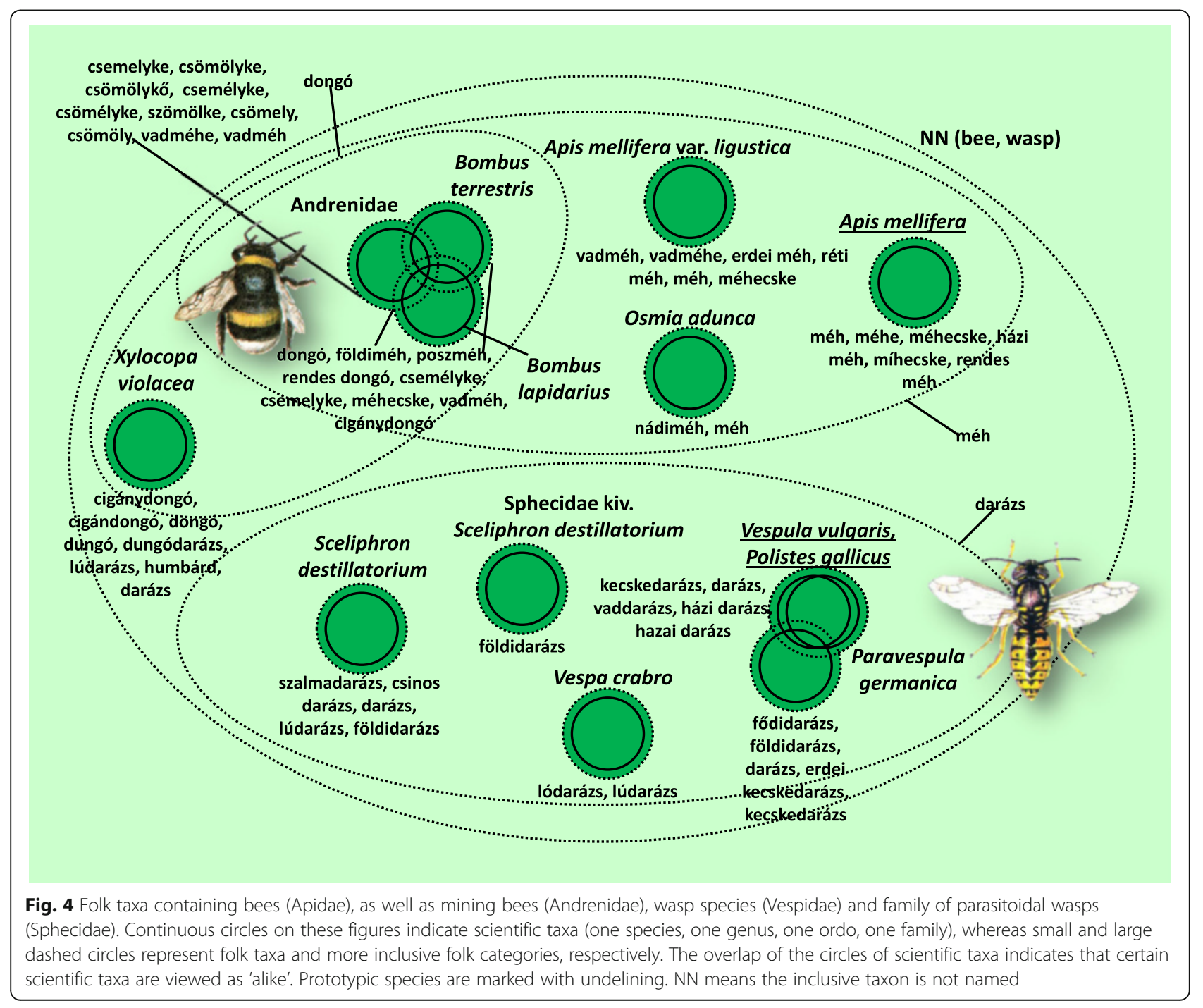


informants. There are two possible reasons for this: 1) the erosion of knowledge (e.g. reductions in hand harvesting mean less familiarity with the dwarf velvet mite Microtrombidium pusillum); 2) certain species are linked to particular farming activities, and so are not generally known. A beekeeper, for instance, would have better knowledge of bee pests, a herder would be more familiar with sheep parasites. Such species may be completely unknown to other members of the community.

The reliability of the knowledge was very high. Despite carrying out constant checks using cross-questioning, errors, falsifications and slips of the tongue were only registered in very few cases. It was more likely for respondents to answer that they didn't know information or weren't familiar with species. Due to the general aversion towards the majority of invertebrate species, however, the informants were sometimes prone to exaggeration. A similarly high degree of reliability and low proportion of errors have been experienced in other Central European locations in studies of botanical knowledge $[75,76]$. For some species (e.g. vine louse, itch mite), there was a high proportion of knowledge that was not based on personal experience.

In line with our expectations ( $c f$. [77, 78]), larger species, those occurring more frequently and those with more distinctive morphologies were more widely known. There was also a greater degree of knowledge of species living in habitats closest to the homes of the informants. Animal and human parasites were often exceedingly well-known. Compared with knowledge of vertebrates, the majority of invertebrate taxa were less detailed. At the same time, a quarter of invertebrate taxa were known to an extent which was comparable to that of the best known vertebrate species.

It was surprising to us that so many invertebrate species are known which have, to our knowledge, no economic significance. The reasons for this were not always clear. Human lifestyles have greatly changed, so there is uncertainty concerning how important a given taxon may have been in the past (e.g. the dormouse species', which were once regularly hunted, but which are not used at all today, [72]. Yet there were other species that we did not expect

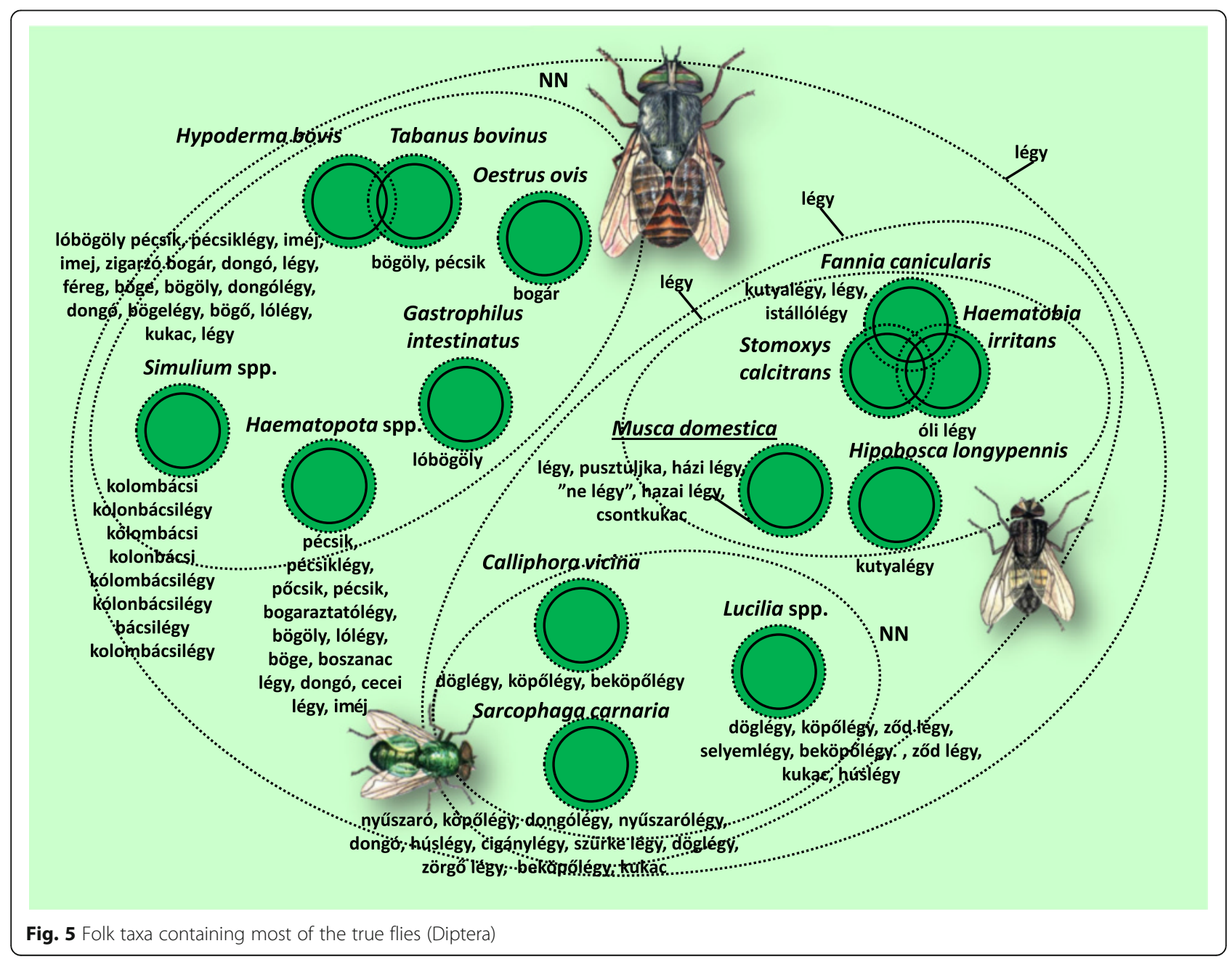


to be widely known which proved, during the study, to be significant even today. Examples are species that have appeared recently, such as Harmonia axyridis, and species of predatory mites that are particularly small, harmless and can be seen on other insects.

Sometimes only the larval form of an animal is known, such as those of the click beetles (Agriotes spp.). In such cases, their place in the taxonomy was less consistent, and often haphazard. The same phenomenon was also often observed in the Sóvidék region (Romania) by Gub [61].

Also surprisingly, informants made no distinction between a significant number of diverse and morphologically easy-to-distinguish lepidopteran species. The hummingbird hawk-moth (Macroglossum stellatarum), with its remarkably unique behaviour, was a relatively frequently seen species. Despite being widely known, astonishingly, it was only given a name in one case, and even this was just the name used within the informant's family.

By comparison, in places where use is made of lepidopteran species (e.g. larvae are eaten in Mexico), up to
67 different species may be known in detail [79]. Species of the order Lepidoptera are an important food source in numerous other regions of the world [80].

We did not find any mythical creatures among invertebrate folk taxa, whereas ethnic Hungarians identify several such animal taxa among vertebrates (e.g. house snake, whistling snake), which are still considered living mythical creatures in the areas under investigation.

With recently settled invasive species or major local invasions of species with a constant lower-level presence, we found that the media played an enhanced role as a source of information. The degree of knowledge sometimes varied greatly, depending on the extent of the invasion, which resulted in some significant differences between the three areas. However, there were only a few species which were known to a varying degree in the three areas (such as the Italian tree cricket, which was more familiar in areas practising viticulture, and Simulium spp., in areas where there had previously been major invasions).

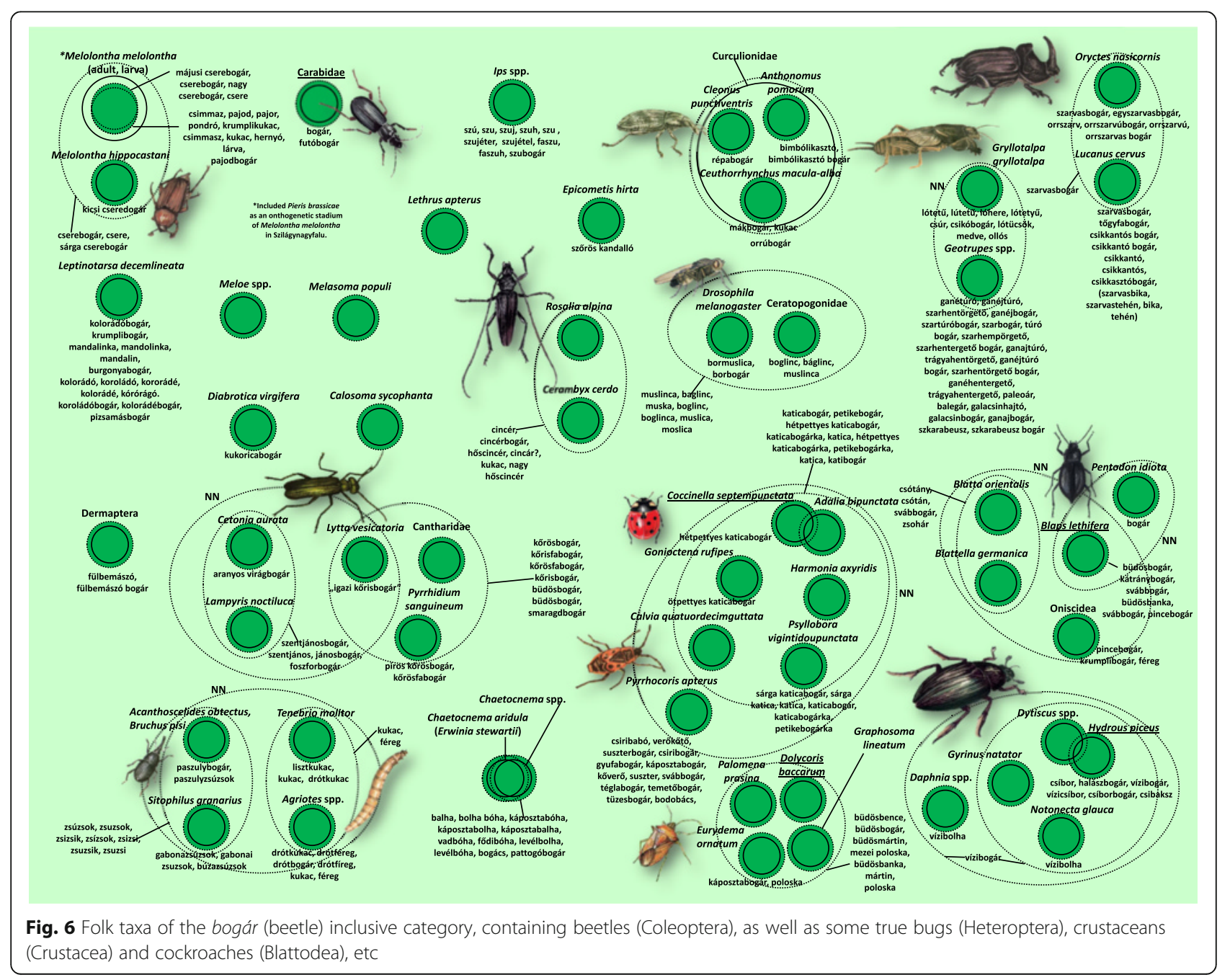


Names - main features and points of interest, unnamed species, modern names

Ninety-three percent of folk taxa had their own individual folk names. The proportion of covert categories was low compared to their higher prevalence among, for example, the Matses of Peru [81]. Where the covert categories are concerned, there is a chance that a few further known folk taxa were not identified during our data collection. The descriptive names used in the case of folk specifics most frequently referred to their morphology or their habitat. A few taxa were only named with the name of the inclusive category.

With some of the taxa, the names given to them within the same community were not consistent. Names could be chopped and changed around even in the case of species that were otherwise clearly separated, such as with locusts, grasshoppers and cicadas; all three of these taxa share the ability to jump, but their size and morphology differ. Almost everybody could distinguish between the three taxa, but the names they used were sometimes swapped around. Berlin et al. [82] also found that people agreed closely on the appropriate names for some species and disagreed markedly on the names of other species.

In a few cases, two or more taxa were given an identical name, even though the fact of their separateness as taxa was widely recognised (e.g. Lampyris noctiluca, Lamprohiza splendidula and Cetonia aurata). The first two are glow worms that light up at night, while the third is a bug (rose chafer) that shines beautifully in sunlight. In our experience, if it was necessary to make a distinction between the first two and the third species, then more knowledgeable informants would, in every case, separate them by adding epithets to the name (e.g. nappali szentjánosbogár [daytime Saint John's bug], or: "the one, which is just a féreg"). In everyday speech, however, the context would determine whether the folk specific referred to the first two or to the third species, so there was no need for separate names.

On other occasions, the same folk name was used for completely unrelated and well distinguished taxonomic groups (e.g. bolha [flea]: Pulex irritans - Chaetocnema

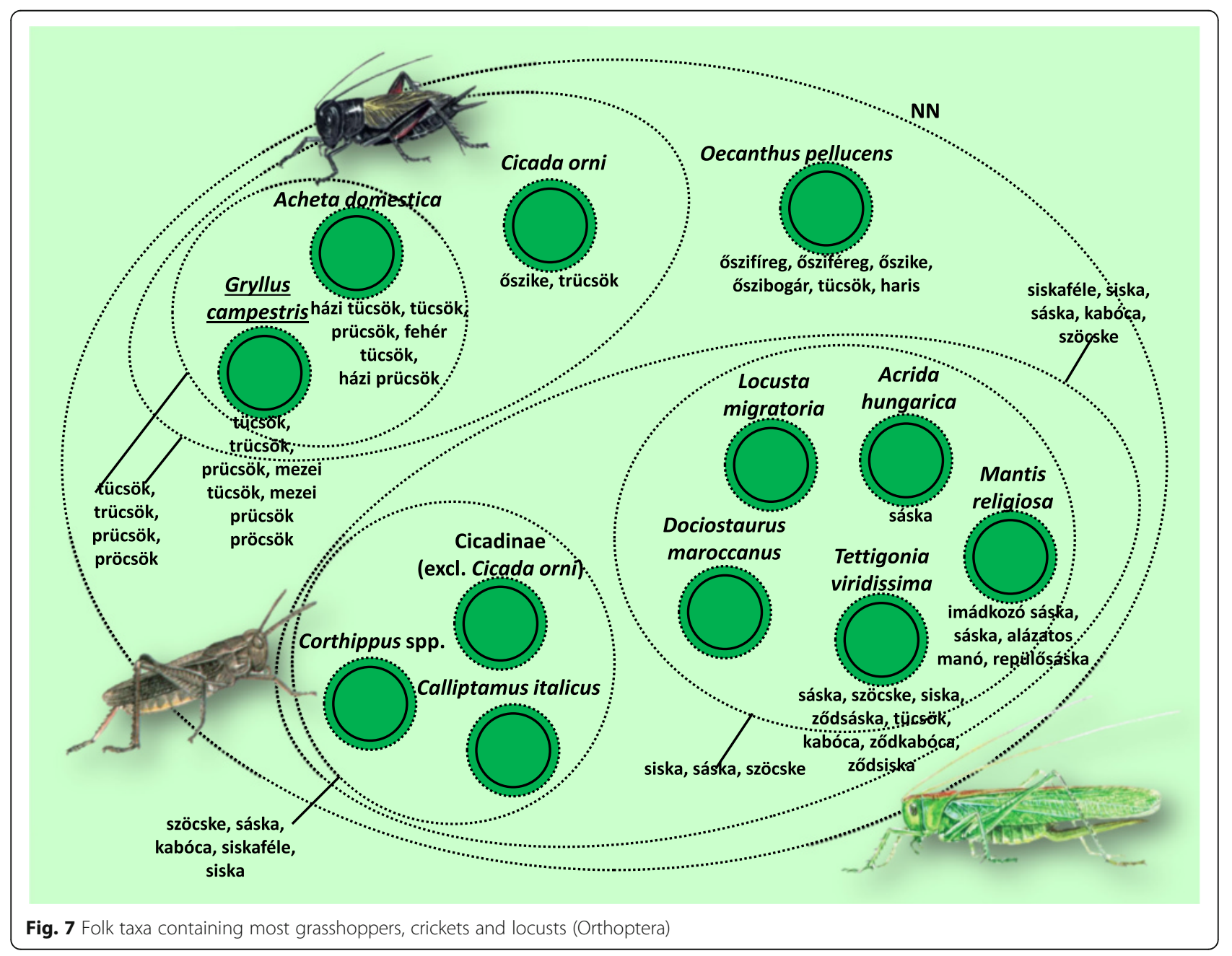


spp.; giliszta [worm]: Lumbricus spp. - e.g. Taenia solium). The names of folk specifics typically made reference to morphological, habitat and ecological properties. There were also instances of the usefulness of the creature being referred to in its name (jópióka - lópióka, 'good leech - horse leech', Hirudo medicinalis - Haemopis sanguisuga). Larval forms were given separate names in several instances (e.g. Hypoderma bovis, Melolontha melolontha, Pediculus humanus capitis), even if the larva and the imago comprised the same folk taxon.

There were several taxa with multiple names. The firebug (Pyrrhocoris apterus) is a generally known species not only in the areas of our investigation, but generally in regions where Hungarian is spoken $[61,62]$. The reason for this may be its distinctive behaviour, or perhaps the fact that hordes of them together can be witnessed in early spring (this phenomenon often also serves as the basis for folk weather forecasts). This species was given a wide range of diverse names. This contradicts the earlier observation [77] that smaller species which cause little or no harm, and which also have no benefit, are often not given names, regardless of how common they are. The proliferation of names also contradicts the observations of Fleck et al. [81], which state, roughly, that the more salient a species is, the more uniform its name will be.

There were far fewer instances of modern names or names used by only one family or individual. Some of these names were humorous, such as pizsamás bogár [pyjama beetle] for Leptinotarsa decemlineata, or vizibizigli (paddled boat) for the waterstriders. This phenomenon has been observed, although similarly infrequently, in botanical studies [83].

Names and other types of knowledge could, in certain cases, be a hybrid of traditional and scientific knowledge. However, the overwhelming majority of the knowledge recorded in our study had a traditional, folk background. Only rarely did some names come to light which derived from formal education or from the media (e.g. aranyos virágbogár [golden flower bug] - Cetonia aurata; aranyszemü fátyolka [gold-eyed veil] - Chrysopa perla). It is more common for the official Hungarian scientific

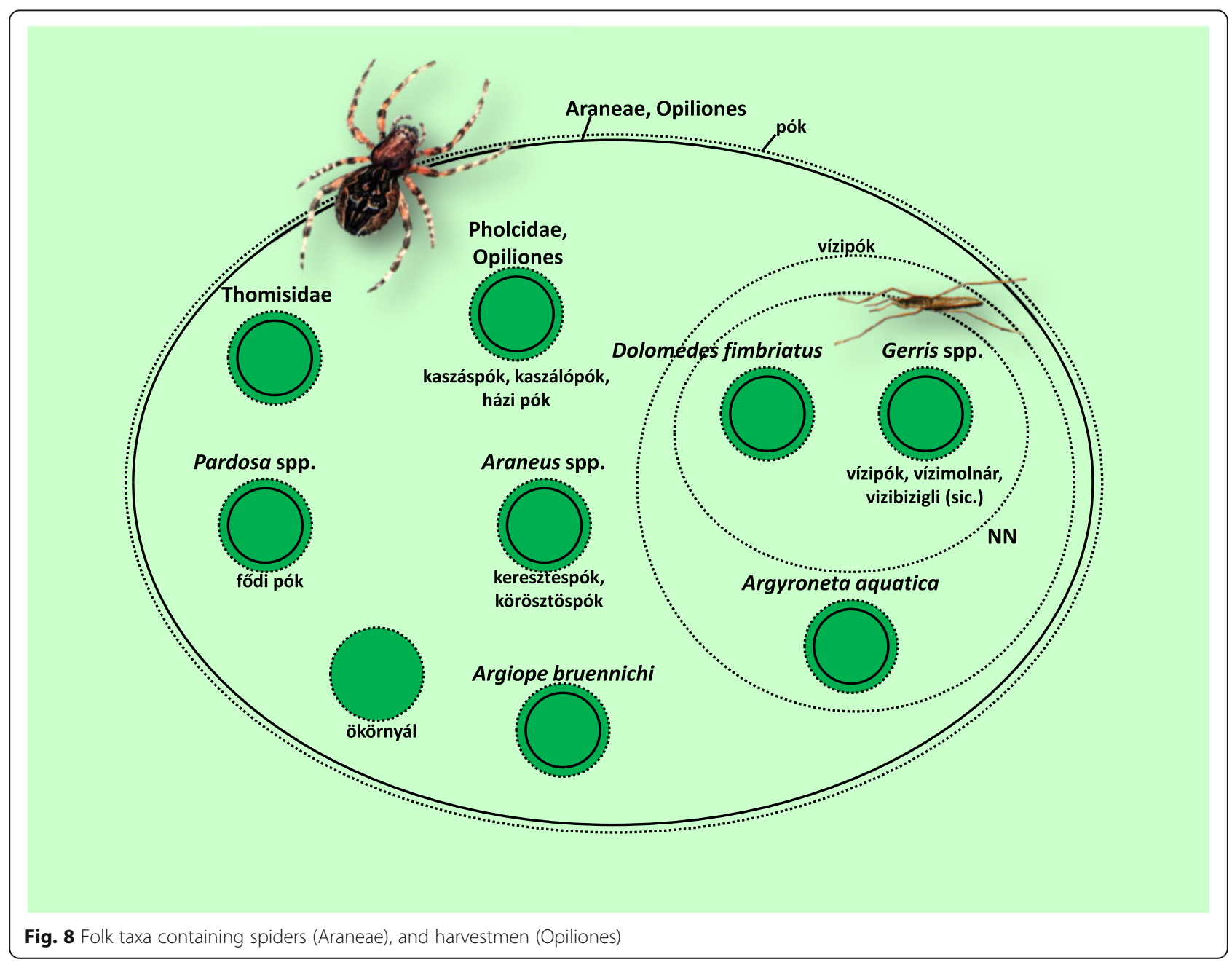


names to originate from folk names. The balance in favour of traditional knowledge is stronger for invertebrates than it is for vertebrates [72]. The influence of schooling could only be felt among a few informants and only for a very limited number of species. In Appendix, all the names used by local people which demonstrably originate from "modern" sources (school, media, books, etc.) have been underlined.

Folk taxonomy, folk nomenclature and salient features The folk taxonomy and nomenclature for the 208 folk taxa are presented in Figs. 3, 4, 5, 6, 7, 8, 9, 10, 11, 12, 13 and 14. Further data (English equivalents, salient features, main habitats and proportion of people who knew the taxon) are contained in Appendix. 16 prototypic species have been recognised, sharing the following features: their names consisted mostly of one simple noun, and within each inclusive taxon they represented the most typical behaviour, were usually the most common species, or could serve as a basis for comparison due to some other feature.
The group containing all the hymenopteran taxa except for ants and gall wasps (Fig. 4) did not have its own separate name. Informants tended to divide this group into three parts: méhek (bees), darazsak (wasps), and dongók (bumblebees), the latter of which had a certain overlap with the méhek (bees) taxon. Prototypic species could only be identified for the first two, more stable groups.

The group called légy (fly) included a significant proportion of true fly (Diptera) species, and not a single group belonging to a different scientific taxon (Fig. 5). The dipteran folk taxa were distinguished primarily according to ecological salience, and secondarily according to morphological salience, into widely known taxa. The dipteran taxa Fannia canicularis, Stomoxys calcitrans and Haematobia irritans were not known to many informants, and could only be partly differentiated, never entirely. This state of uncertainty is reflected in the diagram with overlapping circles. We recorded knowledge of a total of 24 dipteran species, although informants did not include them all and always to the inclusive Diptera category.

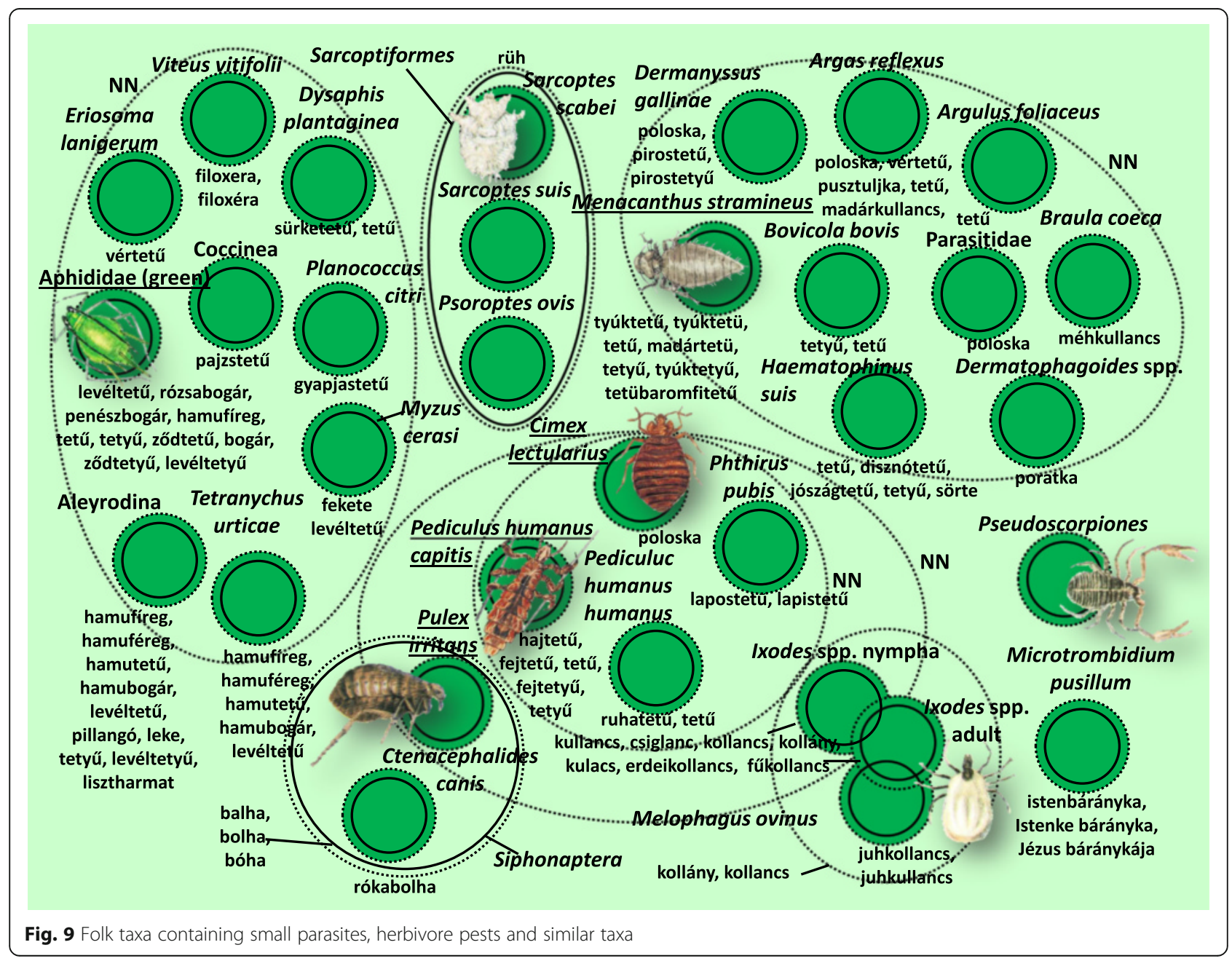




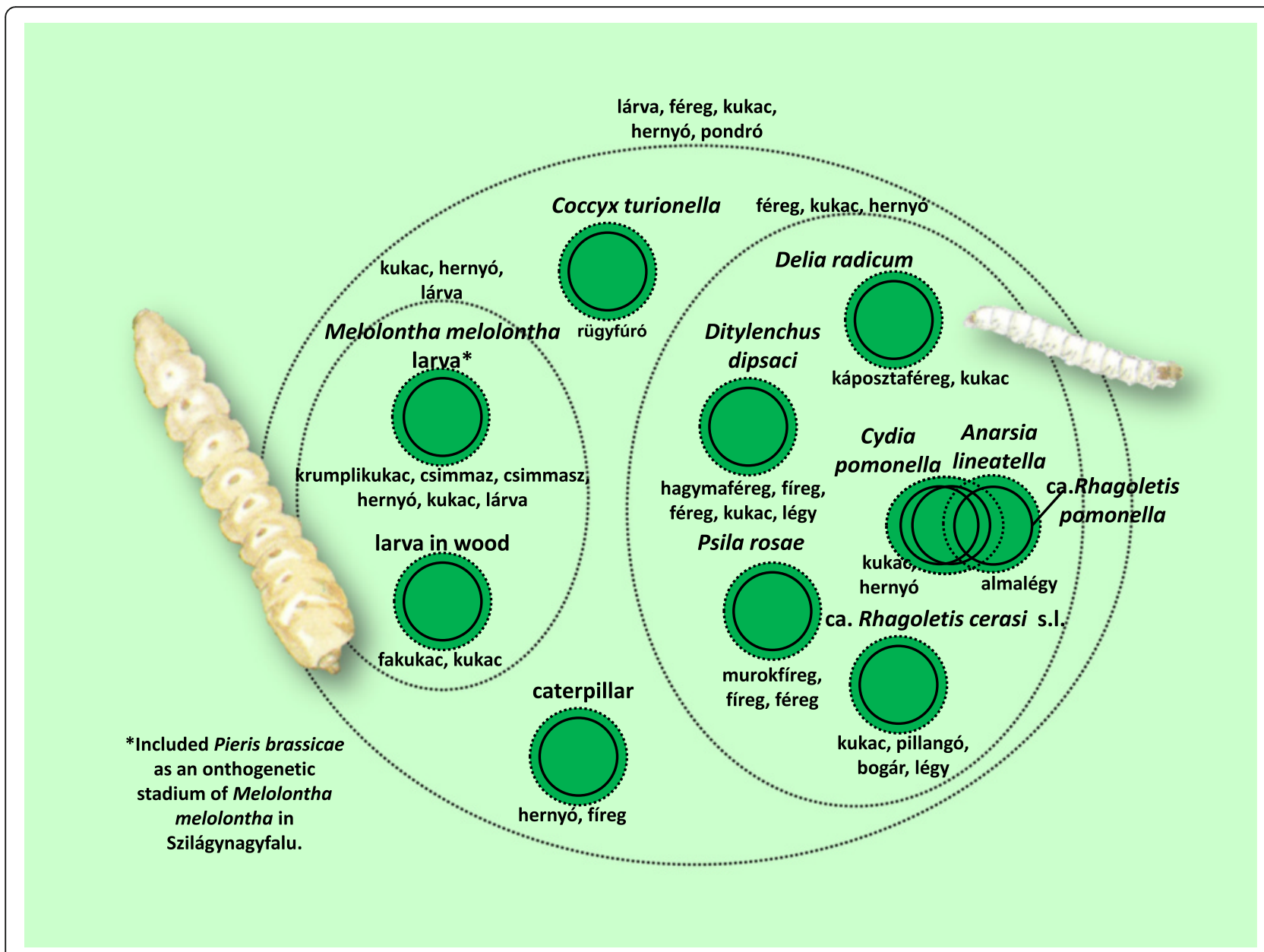

Fig. 10 Folk taxa containing the larvae of some arthropods

The sole group to contain a large number of taxa was the one referred to as bogár (beetle or bug, cf. [45]), which totalled 48 folk taxa (Fig. 6). As with many of the inclusive folk taxa, there were no sharp divisions here either. With species that do not strictly belong in the group of beetles there were further instances of the name bogár (beetle) being used, but the species that feature in Fig. 6 are the ones that could be classified with greater certainty in the folk taxon of bogár (beetle). The key attributes for classification were the hardness of the integumentary system and the shape of the species. The most common taxa in this group were those with a hard chitinous covering and those belonging to the scientific order Coleoptera.

The folk prototypic species for the entire group of beetle (bogár) were primarily the black-coloured members of the family of ground beetles (Carabidae). The prototypic species for inclusive taxa with fewer members were the seven-spot ladybird (Coccinella septempunctata), the great silver water beetle (Hydrous piceus), and so on. There were examples of taxa at two separate levels being given the same name, even though the informants could clearly distinguish between the levels (see vízibogár [water beetle]).

The flea beetles (Chaetocnema spp.) constituted a special case. Here, the complex phenomenon was identified using a single taxon, the combined presence of a Chaetocnema species and an Erwinia bacterium species, which causes leaf dieback that forms a distinctive pattern.

Among ladybirds (Coccinellidae), informants could distinguish 5 or 6 species. The harlequin ladybird (Harmonia axyridis), a recently arrived invasive species, was almost universally known. In the year it appeared, this species was immediately noticed everywhere, and viewed as alien and harmful. The firebug (Pyrrhocoris apterus) is well known in every settlement, and has a wide variety of names (13 different names in the three areas).

Within the inclusive taxon of bogár (beetle), there were also instances of species with markedly different appearances (even to an untrained eye) being classified together. For example, the European mole cricket (Gryllotalpa 


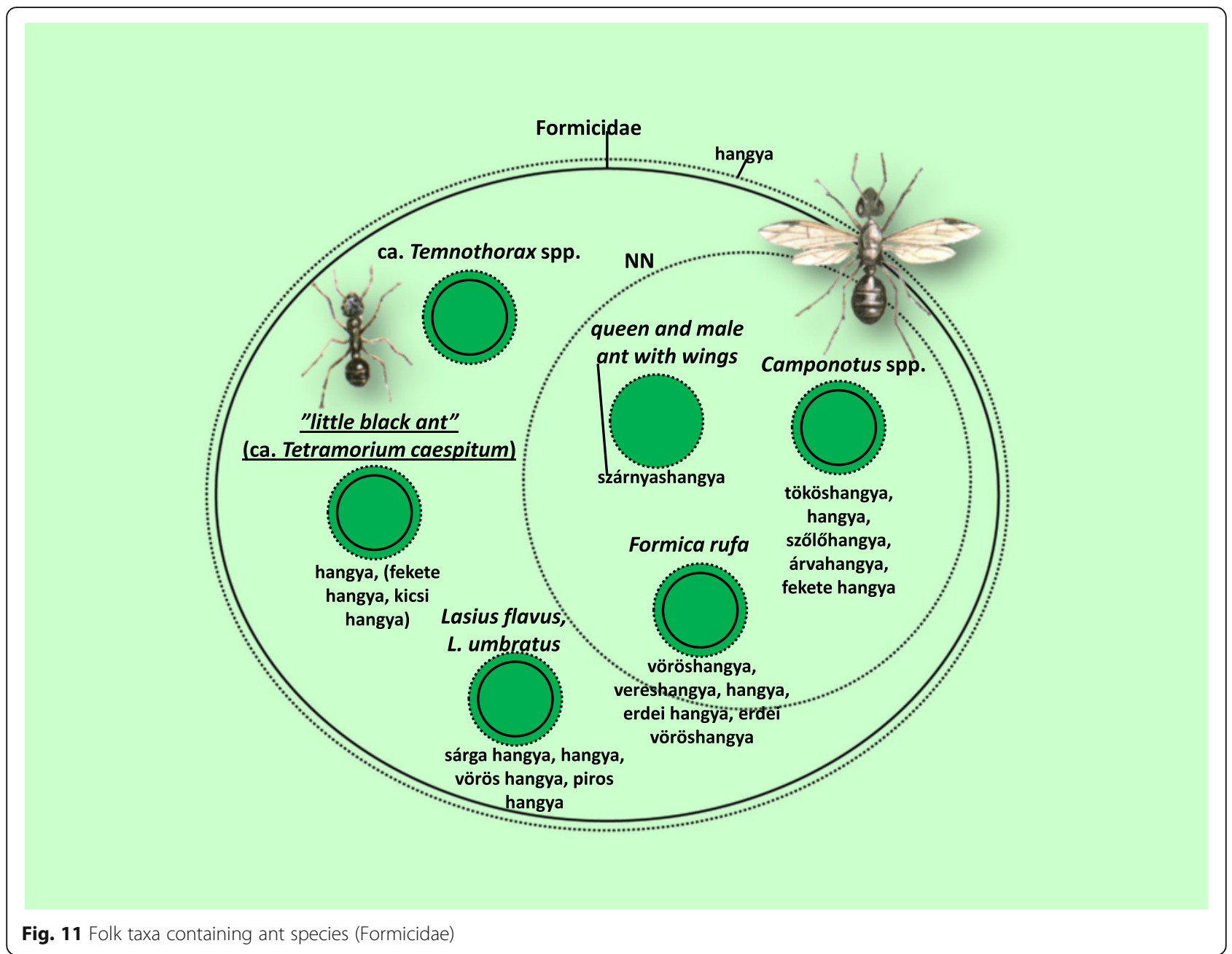

gryllotalpa) was associated with the dor beetles (Geotrupes spp.), with the reason given that these species are found close to animal faeces.

The cockchafer (Melolontha melolontha) and its larva appeared in two (sometimes three) separate places within the folk taxonomy. In addition to the separation of the larva and the imago, the caterpillar of the large white butterfly (Pieris brassicae) (and, to a lesser extent, other species of butterfly) as well as its imago were regarded as stages in the ontogenetic development of the cockchafer. This was particularly true of the Sălaj area, although other scattered data [84] indicate that this view is common among much of the ethnic Hungarian population of Transylvania.

The folk taxon containing mostly orthopteran species only differed from the scientific classification in the absence of the European mole cricket (Gryllotalpa gryllotalpa). It did, however, contain the majority of cicadas (Fig. 7). The prototypic species in this taxon was the field cricket (Gryllus campestris). The distinction between this and the Italian tree cricket (Oecanthus pellucens), and therefore the entire classification as well, differed significantly among the different areas (in Sălaj all informants knew the distinction, but only one made the distinction in Gemer).

The harvestmen (Opiliones) and cellar spiders (Pholcidae) are different groups at ordinal level, but the informants treated them as a single folk specific (Fig. 8). The waterstriders (Gerris spp.), although belonging to the Heteroptera, were also included among folk spider species.

There was justification for classifying smaller parasites, plant pests and other similar species together (Fig. 9), although it was not possible to confine this group within an inclusive taxon that ruled out all uncertainty. The group was heterogeneous in terms of both the scientific taxonomy and the various folk saliences. The number of known species is high, and they were very accurately identified. There was a high number of taxa that had their own prototypic species [species of green aphid, chicken body louse (Menacanthus stramineus), bed bug (Cimex lectularius), head louse (Pediculus humanus capitis), human flea (Pulex irritans)]. 


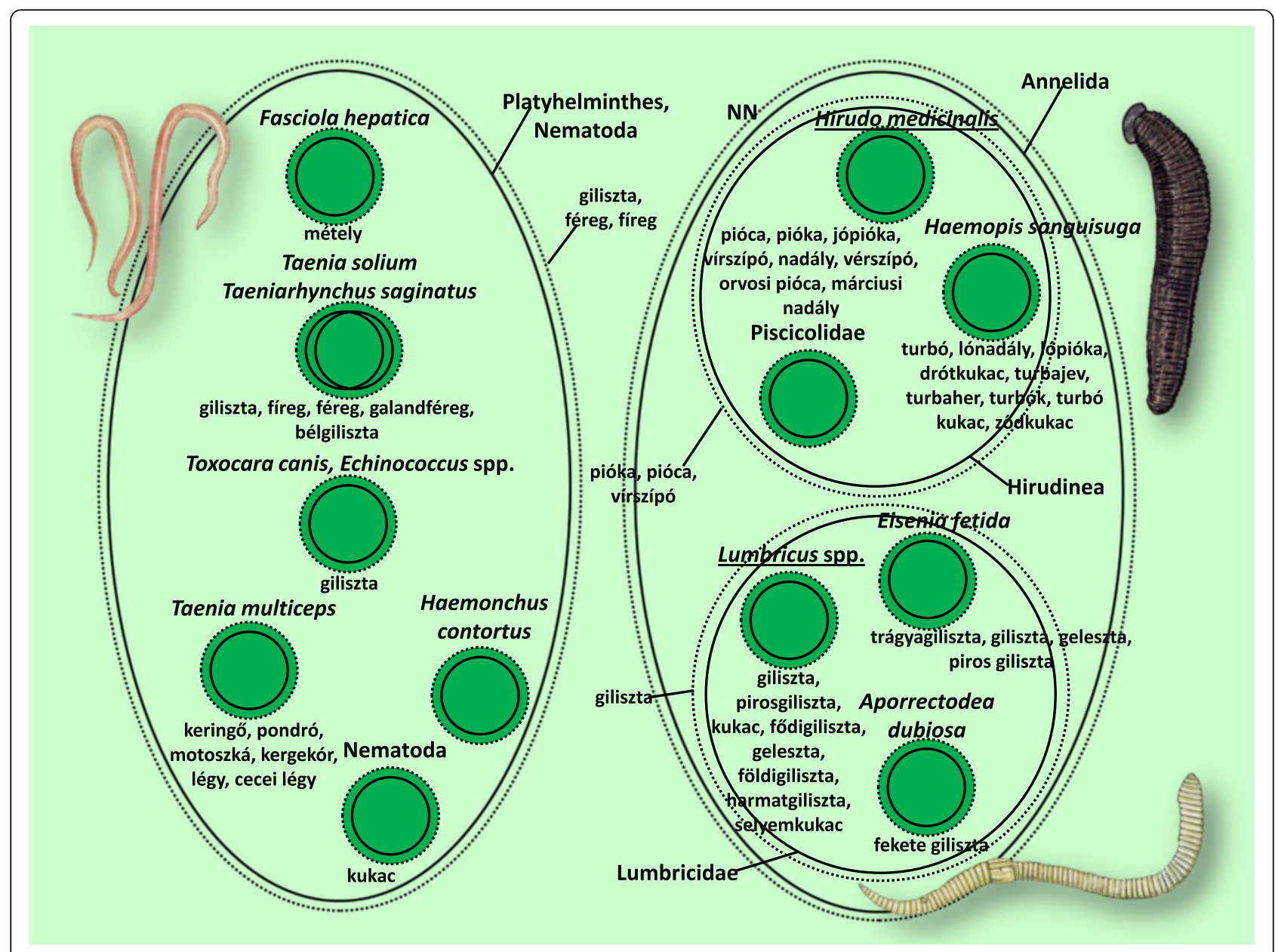

Fig. 12 Folk taxa containing flatworms (Platyhelminthes), as well as roundworms (Nematoda), and ringed worms (Annelida)

Figure 10 shows the majority of the larvae of insect species. This was the most uncertain of the inclusive taxa, and was not regarded as an independent group by many of the informants.

Within the category of ants, there was one clearly defined folk taxon, namely the winged castes of the most diverse species of ant (Fig. 11).

Figure 12 shows the ringed worms (Annelida), flatworms (Platyhelminthes) and roundworms (Nematoda). The folk taxonomy of the ringed worms completely mirrored the scientific taxonomy, even at the level of two supraspecific taxa. In the case of the flatworms and roundworms, less information is available.

Within the molluscs, the group of snails and slugs was very clearly defined (Fig. 13). The bivalves sometimes shared associations with other molluscs (in their names, for example), but they were more frequently linked with frogs. Informants whose folk knowledge had suffered from the least amount of erosion almost exclusively regarded bivalves as the eggs of certain frog species (mostly Pelophylax and Rana).
Apart from the overlap with the cockchafer (Melolontha melolontha) and the special classification of lepidopteran caterpillars, the folk taxon of lepidopterans was also quite intact, and largely in agreement with scientific taxonomy (Fig. 14). Two additional folk taxa were included here which are classified differently according to entomologists: the moth flies (Psychodidae) and the lacewings (Chrysopa spp.).

Only a few invertebrate taxa were left out of all inclusive categories. Most of these remained alone during the pile sorting exercises. They could, on very rare occasions, be sorted into one group or other, although inconsistently, and without true conviction. Such taxa included e.g. the Tisa mayfly (Palingenia longicauda) and the froghoppers (Cercopidae) (Fig. 15).

Figures 3, 4, 5, 6, 7, 8, 9, 10, 11, 12, 13 and 14 show that $90 \%$ of the taxa were embedded in the taxonomy, with generics and specifics dominating. The greatest degree of knowledge was connected to the more inclusive categories (and not to generics or specifics) primarily in the case of spiders, and to a lesser extent the snails, ants 


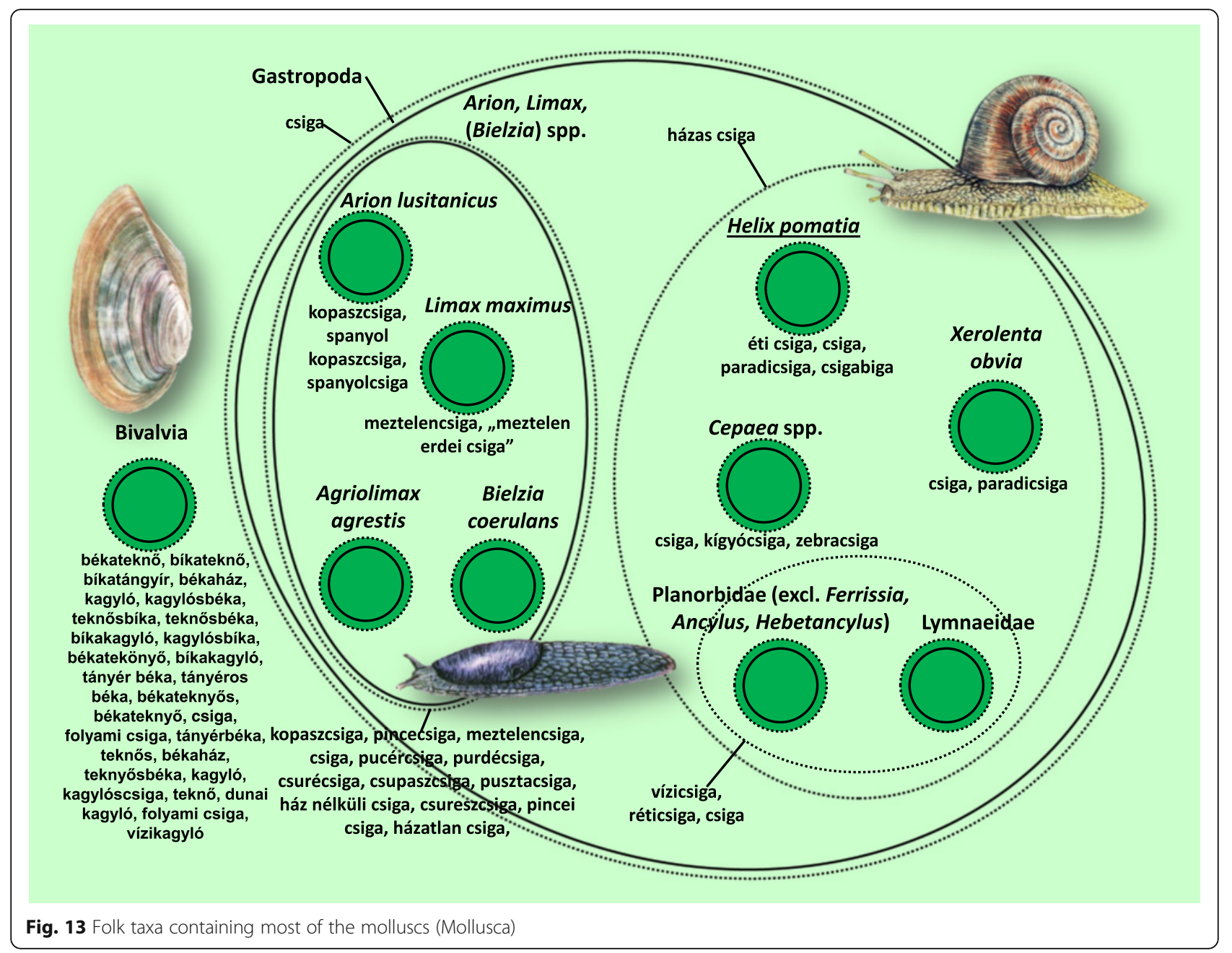

and lepidopterans. Berlin et al. [82] argued that biological species differ considerably in their overall distinctiveness from one another, and this differential distinctiveness leads to the formation of folk generic categories of differing degrees of perceptual importance. A significant part of the taxonomic literature, however, is about vertebrates, and the basic principles established in the literature often do not work with invertebrate groups. Among invertebrates, there is greater importance attached, for example, to prototypic species. These play an important role in taxonomic identification [81]. Nevertheless, the prototypic species were often given only brief descriptions by our informants. The reason for this may lie in the fact that these prototypic species were used as the basis for comparison. In such cases, the less typical species were the ones requiring more detailed descriptions, because they are being compared with and differentiated from the prototypic species.

Within a folk specific, we generally found species that were related from a scientific point of view. It was rare to find taxa that were far removed from each other according to scientific classification. As an example of the greatest distance, harvestmen (Opiliones) and cellar spiders (Pholcidae) (2 scientific orders) were identified as a single folk specific. The reason for this is probably because their physical structures are very similar (especially long legs). In line with previous findings [71], folk taxonomic relations were, to a significant extent, based on the morphological appearance of the taxa. The parallel with the scientific taxonomy was therefore surprisingly precise (especially in the case of ringed worms).

One interesting belief resulted in a quite remarkable taxonomy. The connection between bivalves and frogs is generally known in Sălaj, but was only reported by the most knowledgeable informants in Baranja. In the past, this knowledge may have been more widespread here as well. The connection between the two species is even reflected in the name of the bivalves (békateknö - "frog tub"). We could not find out how or where this belief originated. It is hard to perceive any axis on the bodies of the bivalves, so it could be that they were not regarded as an animal species in their own right for this reason. When touching 


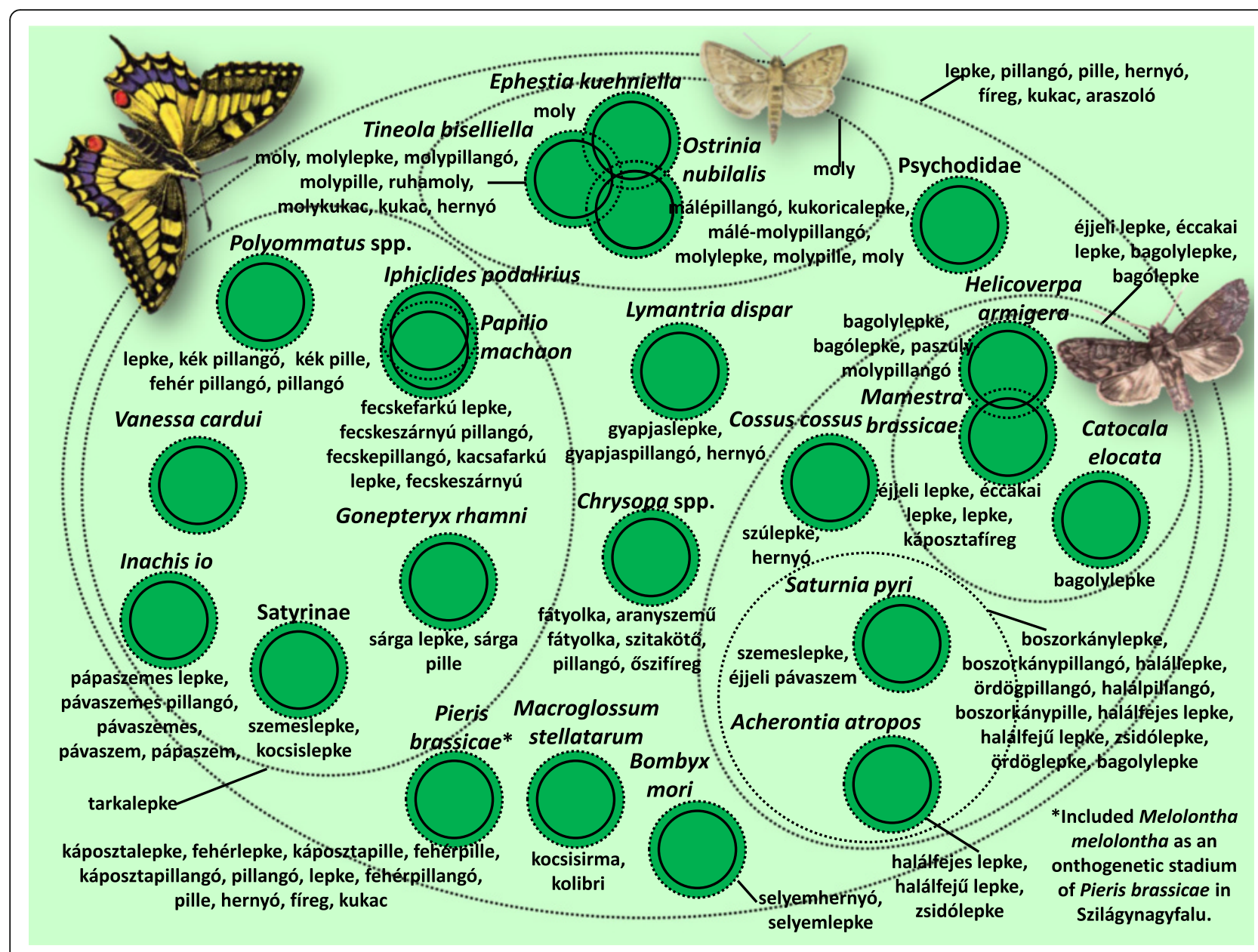

Fig. 14 Folk taxa containing moths and butterflies (Lepidoptera) and some other taxa

the body of the bivalves, the experience is similar to touching the slimy skin of a frog, and furthermore, they live in the same habitat. Thanks to the media, and perhaps from speaking to relatives who have been to the seaside, many informants have now heard of seashells. The majority of these were called kagyló (shell), and they were sharply distinguished from freshwater species. More knowledgeable informants said that the seashells were, like their freshwater equivalents, the eggs of frogs. However, slight majority recognised that they are separate species. Several informants could identify tadpoles (one of the common folk names is kutyahal - "dogfish"), although surprisingly they were unaware of their relationship with fully grown frogs. Tadpoles therefore exerted no influence on the supposed link between bivalves and frogs. In Ghimeș (Gyimes, Romania), the tadpoles of the yellowbellied toad (Bombina variegata) are used in veterinary medicine. The connection between the spawn (tojás egg), the tadpole (békapinty, frog carp?) and the mature adult is recognised for all common species of frog occurring there [85].
Sometimes species were classified not (only) according to morphological salient features, but (also) ecological and cultural features (e.g. Geotrupes spp., Gryllotalpa gryllotalpa). In other words, species which are clearly different from each other, even to an untrained eye, could sometimes be placed into the same taxonomical group. In such cases, morphology, the default first priority when making classifications [71], was replaced by ecological differentiation.

A few species were included in the taxonomy which were not universally viewed as animals, with some informants describing them as diseases rather than species of fauna. These included the liver fluke and species of mite. This uncertainty may derive from the small size of the creatures, or from the fact that they are hard to observe. The small size of the animals involved may also be the main reason behind the various explanations given for the origin of "cuckoo spit" (meadow froghopper foam nests), Erwinia infestations of maize, and gossamer. These three phenomena were regarded as structures created by the most diverse range of species, and in the 


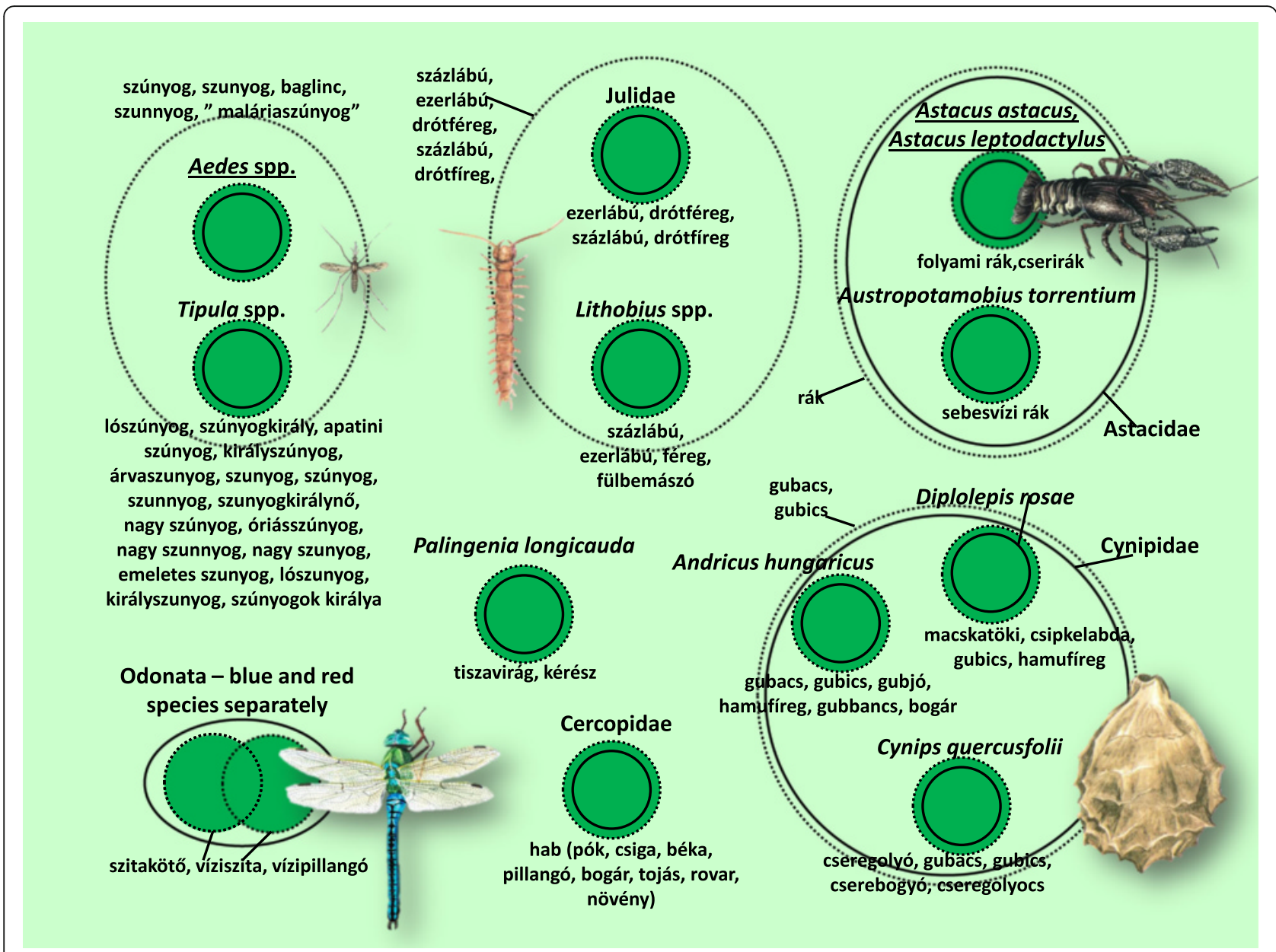

Fig. 15 Smaller folk taxa containing other arthropods

case of gossamer, several informants described it as a weather phenomenon.

Among the inclusive taxonomic categories, the one known as bogár [beetle] is closest to the "wug" taxon introduced by Brown [86]. "Wug" in the three regions studied included most invertebrate species, such as beetles, butterflies, bees and flies; it did not include molluscs, and only rarely did it also include flatworms, roundworms or ringed worms, so as a category it more or less covered the arthropods. The name férgek [worms], also often used as an inclusive category, was less readily applicable to the folk taxonomy. Sometimes the name was used for wormlike creatures, at other times it was applied to other invertebrate pests. In extreme instances, it even encompassed the house mouse, the wolf, the bear ( $c f$. [63]), or indeed any animal regarded as harmful in any way.

\section{Human uses of invertebrate taxa}

A total of 24 invertebrate species were documented as being of direct use to humans (Table 1). The use of invertebrates in our study areas was much less significant, than the role of plants in nutrition and medicine (e.g. [76, 87, $88]$ ), or the role of insects in nutrition and medicine in other parts of the world $[89,90]$. Four species were used for medicinal purposes, 5 species were consumed, 11 were used as bait for fishing, and 2 species were used as playthings. Compared with the tropics (27 medicinal species [91]; more than 200 edible species [92]) this is much lower both in diversity and in terms of the body mass of the invertebrates used.

Andricus hungaricus and Cynips quercusfolii were known to be used for tanning leather, although rarely. Even less commonly, Lytta vesicatoria was mentioned as an aphrodisiac, and Daphnia spp. were used as food for aquarium fish.

Completely new was the discovery that the honey stomachs of black-coloured carpenter bees (Xylocopa violacea, $X$. valga) were consumed even when there was no shortage of alternative foods. This practice was previously unknown in Europe.

In the last hundred years, the consumption of invertebrates in Europe has traditionally been restricted to just a 
Table 1 List of invertebrate taxa for medicinal use, food, angling, toy and other purposes. The last column indicates which species are traditionally protected by locals

\begin{tabular}{|c|c|c|c|c|c|c|c|c|c|}
\hline & $\begin{array}{l}\text { See } \\
\text { taxonomy } \\
\text { in Fig. no. }\end{array}$ & $\begin{array}{l}\text { Latin and proper } \\
\text { name of folk taxa } \\
\text { (serial number in the } \\
\text { appendix) }\end{array}$ & Saliences & Medicinal & Consumption & Bait & Toy & $\begin{array}{l}\text { Other } \\
\text { usage }\end{array}$ & Protection \\
\hline 1. & 15 & $\begin{array}{l}\text { Andricus hungaricus } \\
\text { Hungarian gall wasp } \\
\text { (132) }\end{array}$ & Used for tanning, but collected here mainly for sale. & & & & $x$ & $x$ & \\
\hline 2. & 13 & $\begin{array}{l}\text { Arion, Limax spp. e.g. } \\
\text { Limax maximus } \\
\text { slug species (14) }\end{array}$ & They are very good for baits (i.e.: for angling). & & & $x$ & & & \\
\hline 3. & 4 & $\begin{array}{l}\text { Xylocopa violacea, } \\
\text { Xylocopa valga } \\
\text { black coloured } \\
\text { carpenter bees (112) }\end{array}$ & $\begin{array}{l}\text { Eats nectar, it doesn't do you any harm. / Drills the } \\
\text { wood like a machine. / We frequently caught it, } \\
\text { took apart and ate the honey from it. }\end{array}$ & & $x$ & & & & \\
\hline 4. & 9 & $\begin{array}{l}\text { Microtrombidium } \\
\text { pusillum } \\
\text { dwarf velvet mite (46) }\end{array}$ & $\begin{array}{l}\text { Sometime it is protected like a taboo. God's Lamb. } \\
\text { It has a cross on its back. }\end{array}$ & & & & & & $x$ \\
\hline 5. & 6 & $\begin{array}{l}\text { Lytta vesicatoria } \\
\text { Spanish fly (86) }\end{array}$ & $\begin{array}{l}\text { If the rabid dog bit someone, you had to feed nine } \\
\text { piece of it to the man. I If you pour (the tincture } \\
\text { prepared from the beetle) onto the head of the } \\
\text { man, he did not shiver any more. }\end{array}$ & $x$ & & & & $x$ & \\
\hline 6. & 6 & $\begin{array}{l}\text { Pyrrhidium } \\
\text { sanguineum } \\
\text { Welsh oak longhorn } \\
\text { beetle (92) }\end{array}$ & We would use them for fishing long time ago. & & & $x$ & & & \\
\hline 7. & 13 & $\begin{array}{l}\text { Helix spp. mainly Helix } \\
\text { pomatia } \\
\text { edible snails (20) }\end{array}$ & $\begin{array}{l}\text { The poor cooked it. / They were collected in } \\
\text { springtime. / They were washed at least ten times. It } \\
\text { was scalded and the foot cut off. It was soaked in } \\
\text { lukewarm water, in cold water, lukewarm again, a } \\
\text { lot of work. / Snails are best before the weeds grow } \\
\text { too high. }\end{array}$ & & $x$ & & & & \\
\hline 8. & 15 & $\begin{array}{l}\text { Astacus astacus, } \\
\text { Astacus leptodactylus } \\
\text { European crayfish, } \\
\text { Danubian crayfish (48) }\end{array}$ & $\begin{array}{l}\text { The old of long time ago caught it, it became red } \\
\text { when cooked. / My father caught many on the Rét } \\
\text { (a marsh), we cooked them in a big pot. In salty } \\
\text { water. / The tail and the nippers are good to eat. }\end{array}$ & & $x$ & & & & \\
\hline 9. & 8 & $\begin{array}{l}\text { Araneae e.g. Tegenaria } \\
\text { domestica spiders (34) }\end{array}$ & $\begin{array}{l}\text { If you cut your feet, you would pick spider net in the } \\
\text { stable and covered the cut to heal. }\end{array}$ & $x$ & & & & $x$ & $x$ \\
\hline 10. & 4 & $\begin{array}{l}\text { Apis mellifera } \\
\text { European honey bee } \\
(113)\end{array}$ & $\begin{array}{l}\text { When the bees are gone we will be gone as well } \\
\text { because there will be nothing to eat. / Honey is } \\
\text { good for a lot of things. }\end{array}$ & $x$ & $x$ & & & $x$ & \\
\hline 11. & 13 & $\begin{array}{l}\text { Bivalvia e.g. Anodonta } \\
\text { cygnea } \\
\text { clams (24) }\end{array}$ & $\begin{array}{l}\text { There were many, fed to the pigs. / You would } \\
\text { make buttons of it. It is good for bait to catch carp } \\
\text { and predatory fish. }\end{array}$ & & & $x$ & & $x$ & \\
\hline 12. & 12 & $\begin{array}{l}\text { Hirudo medicinalis } \\
\text { European medicinal } \\
\text { leech (8) }\end{array}$ & $\begin{array}{l}\text { My aunt had them in a jar, when she had a } \\
\text { headache or neck ache you would put them on. I } \\
\text { Only March leech would be good. / If your tooth } \\
\text { aches, put to your gums, it would suck the bad } \\
\text { blood from it. }\end{array}$ & $x$ & & $x$ & & & \\
\hline 13. & 12 & $\begin{array}{l}\text { Haemopis sanguisuga } \\
\text { horse-leech (10) }\end{array}$ & $\begin{array}{l}\text { It's like the leech but only more gentle. I We would } \\
\text { pick them to catch catfish. }\end{array}$ & & & $x$ & & & \\
\hline 14. & 12 & $\begin{array}{l}\text { Lumbricus spp. e.g. } \\
\text { Lumbricus terrestris } \\
\text { earthworms (11) }\end{array}$ & $\begin{array}{l}\text { My husband would know them because he was a } \\
\text { fisherman and would collect them. }\end{array}$ & & & $x$ & & & \\
\hline 15. & 12 & $\begin{array}{l}\text { Eisenia fetida } \\
\text { redworm (12) }\end{array}$ & $\begin{array}{l}\text { Not all earthworms would do for angling. This is } \\
\text { the best one. }\end{array}$ & & & $x$ & & & \\
\hline 16. & 12 & $\begin{array}{l}\text { Aporrectodea dubiosa } \\
\text { earthworm species } \\
\text { (13) }\end{array}$ & $\begin{array}{l}\text { This is harder and it (the fish) can not pull it down } \\
\text { (from the hook). }\end{array}$ & & & $x$ & & & \\
\hline 17. & 6 & & & & & & & $x$ & \\
\hline
\end{tabular}


Table 1 List of invertebrate taxa for medicinal use, food, angling, toy and other purposes. The last column indicates which species are traditionally protected by locals (Continued)

\begin{tabular}{|c|c|c|c|c|c|c|c|}
\hline & $\begin{array}{l}\text { Daphnia spp. e.g. } \\
\text { Daphnia magna } \\
\text { water fleas (50) }\end{array}$ & $\begin{array}{l}\text { There was a doctor here when we were kids who } \\
\text { had an aquarium and he gave them to the fish. } \\
\text { We would go to collect them with a little dipping } \\
\text { net. }\end{array}$ & & & & & \\
\hline 18. 6 & $\begin{array}{l}\text { Gryllotalpa gryllotalpa } \\
\text { European mole cricket } \\
\text { (63) }\end{array}$ & $\begin{array}{l}\text { This is a good bait (to angle). / They were gathered } \\
\text { to put on bottom hooks, there were some } 200 \\
\text { bottom hooks attached on a single string. }\end{array}$ & & $x$ & & & \\
\hline 19. 6 & $\begin{array}{l}\text { Cerambyx cerdo } \\
\text { great capricorn beetle } \\
\text { (90) }\end{array}$ & $\begin{array}{l}\text { I would pick them out for bait (from firewood). In } \\
\text { winter, when I can't get earthworms. }\end{array}$ & & $x$ & & & \\
\hline 20. - & $\begin{array}{l}\text { different beetles and } \\
\text { other bigger insects }\end{array}$ & cruel playing with living individuals & & & $x$ & & \\
\hline 21. 6, & $\begin{array}{l}\text { Melolontha } \\
\text { melolontha } \\
\text { cockchafer (88) }\end{array}$ & $\begin{array}{l}\text { You can angle with it nicely. When it has time } \\
\text { (swarming), fishes like it. }\end{array}$ & & $x$ & & & \\
\hline 22. 6 & $\begin{array}{l}\text { Coccinella } \\
\text { septempunctata } \\
\text { seven-spot ladybird } \\
(97)\end{array}$ & $\begin{array}{l}\text { We are scared that they (Harmonia axyridis) will kill } \\
\text { off all of our nice little ladybugs. Oh, those littles. } \\
\text { Which is a pity, because they are good. }\end{array}$ & & & & & $x$ \\
\hline 23. 4 & $\begin{array}{l}\text { Osmia adunca } \\
\text { mason bee species } \\
(115)\end{array}$ & $\begin{array}{l}\text { We picked out the reed (from the roof), when we } \\
\text { saw that there was reed honey in it. My } \\
\text { grandmother was very angry and scored at us } \\
\text { because we destroyed the reed roof beehive and we } \\
\text { then ate the reed honey. }\end{array}$ & $x$ & & & & \\
\hline 24. 15 & $\begin{array}{l}\text { Cynips quercusfolii } \\
\text { gall wasp species } \\
\text { (130) }\end{array}$ & $\begin{array}{l}\text { We were kids and made pipe of it. It was a toy. I } \\
\text { Oak galls would be used for tanning leather in the } \\
\text { past. }\end{array}$ & & & $x$ & $x$ & \\
\hline 25. 14 & $\begin{array}{l}\text { Lepidoptera e.g. } \\
\text { Melitaea athalia } \\
\text { butterflies (135) }\end{array}$ & $\begin{array}{l}\text { This is indeed not a pest. We were glad to see it } \\
\text { before. They are aware of the harm many species } \\
\text { do, yet adult individuals are not destroyed. }\end{array}$ & & & & & $x$ \\
\hline
\end{tabular}

few species [93], and in the areas of our investigation, they were only consumed occasionally. The consumption of nádiméz (honey in the tube of the reed) from thatched roofs was quite widespread among children, but the decline of this practice may be due to the gradual replacement of thatching as a roofing material. Molluscs are consumed relatively commonly across the globe $[14,26]$, and this was also true for the three study areas in the past [94]. Surprisingly, the idea of consuming edible snails was mostly rejected as disgusting by the informants, and it was only among the most elderly informants in Baranja that there was any tradition of eating edible snails.

The use of Spanish fly (Lytta vesicatoria) was well known, although very few informants had actually seen it used in practice. Its consumption was sometimes linked to superstitious elements such as consuming a "magic number" (9) of beetles placed in palinka (distilled fruit spirit), and mixing them with "randomly" found dog faeces. Blister beetles are used the world over to treat incurable or barely curable illnesses [95], and in our study areas, they were previously used as an antidote to rabies.

We found that leeches were used in four ways: 1) placed on the neck to reduce blood pressure, 2) for treating symptoms of periodontitis, 3) as a painkiller, by increasing the flow of blood as well as from the analgesic entering the bloodstream, 4) as a fishing bait. One species (European medicinal leech - Hirudo medicinalis) has a medicinal effect, while the other (horse-leech - Haemopis sanguisuga) does not. Detailed morphological knowledge was of great importance here. In the Carpathian Basin, it is common for medicinal and non-medicinal plant species also to be given the prefix of orvosi (medicinal) or ló-/kutya- (horse/dog), respectively $[75,76]$.

The use of invertebrate taxa for veterinary medicine was not documented in any of the areas under investigation, although such practices are known in the region. In north-east Romania, for example, spiders are used to treat flatulence in cattle by rubbing the spider into the animal's side [Ulicsni ined.].

Contrary to our expectations, we did not document any current uses for blister beetles or slugs. The use of slugs as a lubricant of cartwheels [51] was not mentioned in our study areas. Based on other data collections, however, this practice was known in the Carpathian Basin [Molnár ined.].

\section{Proverbs and sayings}

Invertebrates are featured in a number of proverbs and sayings (Table 2). During data collection, a total of 30 
Table 2 Proverbs and common sayings referring to Invertebrata

\begin{tabular}{|c|c|}
\hline $\begin{array}{l}\text { Latin name, proper name (serial number in } \\
\text { the Appendix) }\end{array}$ & Proverbs, their meanings and explanations \\
\hline \multirow[t]{2}{*}{$\begin{array}{l}\text { Coccinella septempunctata } \\
\text { seven-spot ladybird (21) }\end{array}$} & $\begin{array}{l}\text { We said to it: ladybug, where do you take me to get married? Then we married in the direction } \\
\text { where it flew. }\end{array}$ \\
\hline & Vernacular prophecy. \\
\hline \multirow{2}{*}{$\begin{array}{l}\text { Planorbidae (excl. Ferrissia, Ancylus, } \\
\text { Hebetancylus) e.g. Planorbis planorbis } \\
\text { ramshorn snails (23) }\end{array}$} & If the snail climbs up from water onto something, it means the flood is coming. \\
\hline & Vernacular prophecy. \\
\hline \multirow{2}{*}{$\begin{array}{l}\text { Gastropoda (excl. slugs) e.g. Zebrina detrita } \\
\text { snails (25) }\end{array}$} & Snail. This is the strongest animal carrying its house on its shoulder. \\
\hline & Joking comparison frequently quoted to kids. \\
\hline \multirow{2}{*}{$\begin{array}{l}\text { Ixodes spp. e.g. Ixodes ricinus } \\
\text { ticks (28) }\end{array}$} & You're like a tick. \\
\hline & Said mostly to kids with an affectionate joking gesture because of their attachment. \\
\hline \multirow{2}{*}{$\begin{array}{l}\text { gossamer } \\
\text { air-threads (44) }\end{array}$} & There will be no rain because it stretches. \\
\hline & Vernacular weather forecast. \\
\hline \multirow{2}{*}{$\begin{array}{l}\text { Microtrombidium pusillum } \\
\text { dwarf velvet mite (46) }\end{array}$} & Shine, sun, shine, Jesus' lamb is freezing to death under the gardens. And then the Sun shone. \\
\hline & A superstition wishing to change the weather. \\
\hline \multirow{2}{*}{$\begin{array}{l}\text { Oecanthus pellucens } \\
\text { Italian tree cricket (55) }\end{array}$} & Autumn is here because the cricket chirps, saying 'gather, gather'. \\
\hline & Wisdom based on observations impersonating the species. \\
\hline \multirow[t]{2}{*}{$\begin{array}{l}\text { Gryllus campestris } \\
\text { field cricket }(61)\end{array}$} & $\begin{array}{l}\text { You could not put down your clothing in the grass because old people said: } \\
\text { the cricket would gnaw a hole in it. }\end{array}$ \\
\hline & Might be a belief. \\
\hline \multirow{2}{*}{$\begin{array}{l}\text { Gryllus campestris } \\
\text { field cricket (61) }\end{array}$} & If you draw a cross on the back of a cricket, it would not jump any more. \\
\hline & Fun for kids based on belief. \\
\hline \multirow{2}{*}{$\begin{array}{l}\text { Pyrrhocoris apterus } \\
\text { firebug (64) }\end{array}$} & They stick together like the firebug. \\
\hline & The firebug (Pyrrhocoris apterus) can be seen in dense masses in springtime. \\
\hline \multirow{2}{*}{$\begin{array}{l}\text { Lytta vesicatoria } \\
\text { Spanish fly (86) }\end{array}$} & The ash tree is stinky, it will rain. \\
\hline & Prophecy connected to Spanish fly invasion. \\
\hline \multirow{2}{*}{$\begin{array}{l}\text { Melolontha melolontha } \\
\text { cockchafer (88) }\end{array}$} & If there are too many maybeetles, corn yields will be good. \\
\hline & Maybe vernacular experience or possibly only a belief. \\
\hline \multirow{2}{*}{$\begin{array}{l}\text { Cerambyx cerdo } \\
\text { great capricorn beetle (90) }\end{array}$} & Your moustache stands up like that of a capricorn beetle. \\
\hline & An analogy on the long moustache bending upwards. \\
\hline \multirow{2}{*}{$\begin{array}{l}\text { Apis mellifera and Araneae } \\
\text { European honey bee (113), spiders (34) }\end{array}$} & Bees collect honey, spiders poison from the same flower. \\
\hline & Meaning of the proverb: there is no universal truth. \\
\hline \multirow{2}{*}{$\begin{array}{l}\text { winged ant castes (120) e.g. Tetramorium } \\
\text { caespitum }\end{array}$} & When the winged ant comes out, it will rain. \\
\hline & Vernacular weather forecast. \\
\hline \multirow{2}{*}{$\begin{array}{l}\text { Tetramorium caespitum and similar species } \\
\text { pavement ant (124) }\end{array}$} & Be like the ant and work! \\
\hline & Ants were considered 'diligent' animals (busy as an ant). \\
\hline \multirow{2}{*}{$\begin{array}{l}\text { Vespa crabro } \\
\text { European hornet (127) }\end{array}$} & Nine hornet bites kill a horse. \\
\hline & Based on real observation, augmented to mythical heights ( 9 is a mythical number in Shamanism). \\
\hline \multirow{2}{*}{$\begin{array}{l}\text { Vespula vulgaris and similar species } \\
\text { common wasp (128) }\end{array}$} & Yellow wasp, small wasp, large wasp, they all scratch on a bunch of grapes. \\
\hline & Pun made of a vernacular observation. \\
\hline \multirow[t]{2}{*}{$\begin{array}{l}\text { Andricus hungaricus } \\
\text { Hungarian gall wasp (132) }\end{array}$} & $\begin{array}{l}\text { My mother made us thrown them away. You must not keep it at the house because brood will } \\
\text { not hatch the eggs. }\end{array}$ \\
\hline & Belief says it prevents brooding of the hen. \\
\hline \multirow[t]{2}{*}{$\begin{array}{l}\text { Lepidoptera e.g. Melitaea athalia } \\
\text { butterflies (135) }\end{array}$} & $\begin{array}{l}\text { The superstition was that if you see a yellow butterfly in spring, you would fall ill. If you see a red one, } \\
\text { you will remain healthy and fall in love, if a black one, someone would die. }\end{array}$ \\
\hline & $\begin{array}{l}\text { Vernacular prophecy. The yellow butterfly may be Gonopteryx rhamni, red ones may be several } \\
\text { other species. }\end{array}$ \\
\hline
\end{tabular}


Table 2 Proverbs and common sayings referring to Invertebrata (Continued)

\begin{tabular}{|c|c|}
\hline \multirow{2}{*}{$\begin{array}{l}\text { Lepidoptera e.g. Melitaea athalia } \\
\text { butterflies (135) }\end{array}$} & Even the mottled butterfly came from a caterpillar. \\
\hline & $\begin{array}{l}\text { You do not necessarily worth more just because of your better appearance or even something ugly } \\
\text { may become beautiful one day. }\end{array}$ \\
\hline \multirow{2}{*}{$\begin{array}{l}\text { Saturnia pyri } \\
\text { giant peacock moth (151) }\end{array}$} & The boszorkánylepke (witch butterfly) were nailed above the door for superstition. \\
\hline & It was used as a superstitious protection against the Devil. \\
\hline \multirow{2}{*}{$\begin{array}{l}\text { Drosophila spp. e.g. Drosophila melanogaster } \\
\text { fruit flies (159) }\end{array}$} & Fruit flies cause the wine to ferment. \\
\hline & In their opinion the presence of fruit flies cause the wine to ferment. \\
\hline \multirow{2}{*}{$\begin{array}{l}\text { Drosophila spp. e.g. Drosophila melanogaster } \\
\text { fruit flies (159) }\end{array}$} & The man from Vörösmart swallowed the frog; he thought it was a fruit fly. \\
\hline & Mocking a village. \\
\hline \multirow{2}{*}{$\begin{array}{l}\text { Tipula spp. e.g. Tipula maxima } \\
\text { crane flies (160) }\end{array}$} & We stroke the mosquito king to death; there will be no mosquitos now. \\
\hline & $\begin{array}{l}\text { The Tipula species which are much greater than biting mosquitos but are related to them are } \\
\text { presented by the saying as a kind of king. }\end{array}$ \\
\hline \multirow[t]{2}{*}{$\begin{array}{l}\text { Musca domestica } \\
\text { housefly (169) }\end{array}$} & $\begin{array}{l}\text { Noah wanted to chase them out from the Bark. He could not. Well, fly, then. He said. } \\
\text { And the name stuck. }\end{array}$ \\
\hline & $\begin{array}{l}\text { Folk etymology for the name of the fly. He blames Noah for the existence of flies. Légy in Hungarian } \\
\text { also means: be (you should exist). }\end{array}$ \\
\hline \multirow{2}{*}{$\begin{array}{l}\text { Musca domestica } \\
\text { housefly (169) }\end{array}$} & If flies bite, rain comes. \\
\hline & Vernacular weather forecast. \\
\hline \multirow{2}{*}{$\begin{array}{l}\text { Pediculus humanus capitis } \\
\text { head louse (191) }\end{array}$} & It's not a shame to get it, only to keep it. \\
\hline & Educating saying on responsibility. \\
\hline \multirow{2}{*}{$\begin{array}{l}\text { Haematopinus suis } \\
\text { hog louse (193) }\end{array}$} & You can find a louse only in a good hog. \\
\hline & In their opinion louses occur on healthy pigs only. \\
\hline \multirow{2}{*}{$\begin{array}{l}\text { Odonata e.g. Sympetrum sanguineum } \\
\text { dragonflies (207-208) }\end{array}$} & Where there are dragonflies, there are no snakes. \\
\hline & It was held that wherever a dragonfly hovers over the water there will be no snakes in it. \\
\hline
\end{tabular}

taxa were associated with a proverb or some other folk wisdom (such as weather forecasting, harvest predicting, similarly to the way in which birds, for instance, are associated in many human cultures [96]). Some of these were based on observations of animal behaviour or experience of their population cycles, and so do have some genuine basis in fact (e.g. the swarming patterns of Lytta vesicatoria). Other folk beliefs, however, were probably closer to old wives' tales (e.g. drawing a cross on the back of a field cricket will prevent it from jumping; the presence of Andricus hungaricus prevents hens from brooding). Forecasts of weather phenomena based on the behaviour of various invertebrates (e.g. winged ants mean that rain is coming) occurred frequently.

The positive attitude towards the presence of hog lice on swine is probably based on the observation that parasites abandon sick or dead livestock. Gub [61] also found examples of healing involving external animal parasites, a practice that can also be deduced from the same kinds of observation.

Games with the invertebrates, and the ill-treatment of animals were quite widespread in the past, although they were not confined to particular species. Nevertheless, larger and more easily caught species, such as Melolontha melolontha, Lucanus cervus and Oryctes nasicornis, were more likely to fall victim. Gub [61] describes several special games involving the cockchafer and the stag beetle.

In addition to Vallejo and González [55], Gub [61] also mentions the use of head lice in human medicine, especially in treating jaundice. We did not document any similar instances, although this practice may well be widespread, and with further research there is a high chance of finding more such cases.

One belief that made a scattered appearance in the areas under investigation stated that a dragonfly hovering about the water indicated that there was no snake in the water. The name recorded for the dragonfly by Gub [61], kígyópásztor (snake-shepherd) may also derive from this belief.

\section{Invertebrate species that enjoy folk conservation or state protection}

Conscious ideas about conserving invertebrates only occurred with a few taxa (see the last column in Table 1). Seven-spot ladybirds, dwarf velvet mites and often spiders were said to enjoy protection, but informants would generally - but not universally - refrain from harming firebugs, field crickets and most butterflies.

With regard to ladybirds, the tradition of protecting them came from the culture (songs and sayings), but 
they were also recognised as useful animals. Many informants knew that they help reduce aphid populations. The taboo about destroying dwarf velvet mites was explained by a few informants as being due to the crossshaped marking on their backs. Many stated that hurting spiders brought bad luck.

Butterflies were respected for their beauty. Here it should be noted that the state protection enjoyed by certain species of butterfly (e.g. Iphiclides podalirius, Inachis io) in Hungary is justified more by their beauty than their rarity.

Field and house crickets were generally left unharmed as a result of their pleasant chirruping and their cultural significance. Surprisingly, most people knew nothing about legal protection for invertebrates.

Also surprisingly, almost every invertebrate species was regarded as basically harmful. Where possible they were destroyed or at least regarded as being worth eradicating. Informants reported little information about the benefits of invertebrates, or did not regard the benefits as significant. Because they are very common, even species that were regarded as useful were not given any protection (for example, fruit flies are believed to aid fermentation). However, we could not find any information to suggest that any invertebrate species had disappeared or become rarer as a result of conscious destruction.

In the areas under investigation, traditional uses of and attitudes towards invertebrates have not revealed any kind of activity that would cause major damage from a nature conservation point of view. The fundamental factors behind this state of sustainability are small-scale farming, which imposes less strain on the environment, and the fact that resources are mostly used locally. Traditional methods of agriculture do without chemicals, so populations of many invertebrate species only began to decline as intensive farming spread (starting in the 1980s).

With the exception of edible snails and in a few cases certain galls the use of invertebrate taxa had remained local, and was therefore sustainable. In areas where the use has spread beyond the locality, for example in Mexico, with invertebrates living in species of Agave [90], or in areas of the Carpathian Basin where edible snails are harvested in big quantity [64], a significant reduction in the prevalence of such species has been experienced. The effects of such destruction have tended to be far more significant with regard to vertebrate taxa ([7], e.g. predatory mammals and birds).

\section{Folk wisdom related to nature as a whole}

Sometimes knowledge pertaining to the taxa could have a more general relevance, and be regarded as folk wisdom concerning the functioning of nature as a whole. The damage caused by the gypsy moth (Lymantria dispar), for example, was regarded as a minor problem, because - according to many informants - major damage does not occur by itself "in nature", only as a result of human intervention. A kind of tolerance was exhibited, especially in connection with species that people were fond of whatever reason, or regarded as relatively harmless, in phrases such as "they have to eat too", or "they are also God's creations". The damage caused by such species is often accepted, and regarded as tolerable and natural. Certain instances of "wisdom" appeared not to originate from traditional folk knowledge. The view that "if the bees disappear, then we will disappear too, because there won't be anything to eat" probably springs from the influence of the media.

Folk wisdom in our study areas was fragmentary, probably heavily eroded, and seemed no longer to constitute a unified, systematic world view, or social conventions that impact on everyday behaviour and thinking, as has been described e.g. in connection with the ontology of Native Indian communities in North America [97-99].

\section{Conclusions}

Despite the fact that our material was gathered only recently, folk knowledge is still alive among Hungarian people in these regions, as are some of the folk uses. We argue, however, that before the dual impact of the market economy and public education became so powerful, Hungarian rural people might have possessed knowledge as deep as that of, for example, the natives of Amazonia. Ethnographic works from the late 19th and early 20th centuries provide the basis for this argument. The high number of known invertebrate folk taxa documented in our three study areas suggests that it would be worth conducting further investigations in other areas of Europe as well.

Local traditional ecological knowledge of invertebrates is highly relevant to helping us understand the mentality and worldview of local people. Understanding local worldviews can be a first step towards developing locally appropriate, culture-specific nature conservation strategies and local school curricula - desperately needed in our globalising world.

\section{Appendix}

For each of the taxa, we collected and documented the local name (or names), their salient features, their uses, any damage they cause, any personal attitudes expressed towards the taxa (positive, negative or neutral), and related folklore issues. The habitats of the species were determined based on our own experiences, on the interviews, and on the scientific literature. Literal quotations are in italics, and comments by individual interviewees are separated by a slash. 
Table 3 Data base of invertebrate folk knowledge among Hungarians

\begin{tabular}{|c|c|c|c|c|c|c|}
\hline & Fig. & $\begin{array}{l}\text { Scientific and } \\
\text { proper names }\end{array}$ & $\begin{array}{l}\text { The most typical local names } \\
\text { and their literal English } \\
\text { translation }\end{array}$ & Saliences & $\begin{array}{l}\text { Key places of } \\
\text { encounter and habitats }\end{array}$ & $\begin{array}{l}\text { Proportion of } \\
\text { informants who knew } \\
\text { the taxon }(\%)\end{array}$ \\
\hline 1. & 12 & $\begin{array}{l}\text { Fasciola hepatica } \\
\text { common liver fluke }\end{array}$ & métely & $\begin{array}{l}\text { It is in the liver of the livestock. It's } \\
\text { like a pumpkin seed cut in half. } \\
\text { Fluky stock is skinny. / You must } \\
\text { not graze it around lakes. Surely } \\
\text { some snail spreads it. }\end{array}$ & $P$ & 64 \\
\hline 2. & 12 & $\begin{array}{l}\text { Toxocara canis } \\
\text { Echinococcus spp. } \\
\text { dog roundworm }\end{array}$ & giliszta & - & $P$ & 9 \\
\hline 3. & 12 & $\begin{array}{l}\text { Taenia solium } \\
\text { Taeniarhynchus } \\
\text { saginatus pork } \\
\text { tapeworm, beef } \\
\text { tapeworm }\end{array}$ & $\begin{array}{l}\text { giliszta, galandféreg } \\
\text { (galandworm) }\end{array}$ & $\begin{array}{l}\text { It can be found in pigs, piglets, the } \\
\text { guts, even in man, as big as half a } \\
\text { metre long was also taken out. }\end{array}$ & $P$ & 38 \\
\hline 4. & 12 & $\begin{array}{l}\text { Taenia multiceps } \\
\text { tapeworm species }\end{array}$ & $\begin{array}{l}\text { keringő (whirler), motoszká } \\
\text { (fumbler) }\end{array}$ & $\begin{array}{l}\text { A fly lays the egg into the nostrils } \\
\text { of the sheep and it goes up to the } \\
\text { brain. When it is developed there, } \\
\text { the sheep would blow it out. If one } \\
\text { does not blow it out, it will get the } \\
\text { circling disease. / Before, we would } \\
\text { operate them. }\end{array}$ & $P$ & 4 \\
\hline 5. & 12 & $\begin{array}{l}\text { Nematoda e.g. } \\
\text { Pseudocapillaria } \\
\text { tomentosa fish } \\
\text { roundworm species }\end{array}$ & giliszta & $\begin{array}{l}\text { These worms like the sterlet } \\
\text { (Acipenser ruthenus) very much, } \\
\text { they get into the stomach. It is thin } \\
\text { like a needle. }\end{array}$ & $P$ & 2 \\
\hline 6. & 10 & $\begin{array}{l}\text { Ditylenchus dipsaci } \\
\text { stem nematode }\end{array}$ & fíreg, kukac & $\begin{array}{l}\text { Onions get worms as well. Small } \\
\text { little worms. Yellowish. }\end{array}$ & $\mathrm{S}$ & 9 \\
\hline 7. & 12 & $\begin{array}{l}\text { Haemonchus } \\
\text { contortus barber's } \\
\text { pole }\end{array}$ & (piros) féreg (red féreg) & $\begin{array}{l}\text { The cow has that manyplies, it } \\
\text { was all full with red worm inside. }\end{array}$ & $P$ & 2 \\
\hline 8. & 12 & $\begin{array}{l}\text { Hirudo medicinalis } \\
\text { European medicinal } \\
\text { leech* }^{*}\end{array}$ & $\begin{array}{l}\text { pióka, vérszípó (blood sucker), } \\
\text { nadály }\end{array}$ & $\begin{array}{l}\text { We would go into the water and it } \\
\text { stuck on our legs. It was collected. } \\
\text { I We would sprinkle ash on it and } \\
\text { parted with the skin. It lives long. } \\
\text { There are people who's blood it } \\
\text { does not like. / The leech is not a } \\
\text { parasite; it was used for medicine } \\
\text { centuries long. }\end{array}$ & $P, W$ & 100 \\
\hline 9. & 12 & $\begin{array}{l}\text { Piscicolidae e.g. } \\
\text { Piscicola geometra } \\
\text { leech species on } \\
\text { fishes }\end{array}$ & pióca & $\begin{array}{l}\text { They kill the fish; suck their blood, } \\
\text { stuck on them. }\end{array}$ & $P, W$ & 5 \\
\hline 10. & 12 & $\begin{array}{l}\text { Haemopis } \\
\text { sanguisuga horse- } \\
\text { leech }\end{array}$ & $\begin{array}{l}\text { lópióka (horse pióka), turbók, } \\
\text { drótkukac (wire worm) }\end{array}$ & $\begin{array}{l}\text { It was dug out from wet earth. / } \\
\text { We call it the wire worm. They are } \\
\text { this big and hard, dark green. I }\end{array}$ & W & 80 \\
\hline 11. & 12 & $\begin{array}{l}\text { Lumbricus spp. e.g. } \\
\text { Lumbricus terrestris } \\
\text { earthworms }\end{array}$ & $\begin{array}{l}\text { giliszta, földigiliszta (earth } \\
\text { giliszta) }\end{array}$ & $\begin{array}{l}\text { Selyemkukac (silkworm) are in the } \\
\text { garden, around the house, under } \\
\text { the bricks, after rain, they breathe } \\
\text { in the fresh air. It's a soft bodied } \\
\text { worm. }\end{array}$ & $S$ & 100 \\
\hline 12. & 12 & $\begin{array}{l}\text { Eisenia fetida } \\
\text { redworm }\end{array}$ & $\begin{array}{l}\text { giliszta, trágyagiliszta (dung } \\
\text { giliszta) }\end{array}$ & $\begin{array}{l}\text { It is beside the dung. / Reddish. } \\
\text { Not so big. }\end{array}$ & $S$ & 10 \\
\hline 13. & 12 & $\begin{array}{l}\text { Aporrectodea } \\
\text { dubiosa earthworm } \\
\text { species }\end{array}$ & fekete giliszta (black giliszta) & It is on the waterside. Black. & W & 2 \\
\hline 14. & 13 & $\begin{array}{l}\text { Arion, Limax spp. } \\
\text { e.g. Limax maximus } \\
\text { slug species }\end{array}$ & $\begin{array}{l}\text { kopaszcsiga (bald snail), } \\
\text { meztelencsiga (naked snail), } \\
\text { csupaszcsiga (nude snail) }\end{array}$ & $\begin{array}{l}\text { It ate members of the cabbage } \\
\text { family. / You could hardly find a } \\
\text { plant which would not be } \\
\text { damaged by them. / It is usually } \\
\text { found such dark cellars. Wherever }\end{array}$ & $A, S$ & 96 \\
\hline
\end{tabular}


Table 3 Data base of invertebrate folk knowledge among Hungarians (Continued)

\begin{tabular}{|c|c|c|c|c|c|c|}
\hline & & & & $\begin{array}{l}\text { it goes, leaves this discharge } \\
\text { behind. / After the rain. / I draw } \\
\text { them from the well. }\end{array}$ & & \\
\hline 15. & 13 & $\begin{array}{l}\text { Agriolimax agrestis } \\
\text { and similar species } \\
\text { smaller field slugs }\end{array}$ & $\begin{array}{l}\text { meztelencsiga (naked snail), } \\
\text { kopaszcsiga (bald snail) }\end{array}$ & $\begin{array}{l}\text { The white ones come in every four } \\
\text { or five years but would then teem } \\
\text { frightfully. }\end{array}$ & A & 4 \\
\hline 16. & 13 & $\begin{array}{l}\text { Arion lusitanicus } \\
\text { Portuguese slug }\end{array}$ & $\begin{array}{l}\text { kopaszcsiga (bald snail), spanyol } \\
\text { kopaszcsiga (Spanish bald snail) }\end{array}$ & $\begin{array}{l}\text { They are visitors here. You would } \\
\text { not find them long ago. / It will } \\
\text { spread here as well. / It came from } \\
\text { Spain with vegetables and are very } \\
\text { prolific. }\end{array}$ & A & 16 \\
\hline 17. & 13 & $\begin{array}{l}\text { Limax maximus } \\
\text { great grey slug }\end{array}$ & $\begin{array}{l}\text { meztelencsiga (naked snail), } \\
\text { meztelen erdei csiga (naked } \\
\text { forest snail) }\end{array}$ & $\begin{array}{l}\text { They would gnaw away } \\
\text { mushrooms instantly. / They would } \\
\text { eat it, whether edible or poisonous. }\end{array}$ & $\mathrm{F}$ & 5 \\
\hline 18. & 13 & $\begin{array}{l}\text { Bielzia coerulans* } \\
\text { Carpathian blue } \\
\text { slug }\end{array}$ & meztelencsigá (naked snail) & You can find blue or grey ones. & $\mathrm{F}$ & 5 \\
\hline 19. & 13 & $\begin{array}{l}\text { Cepaea spp. e.g. } \\
\text { Cepaea } \\
\text { vindobonensis } \\
\text { land snail species }\end{array}$ & csiga, kígyócsiga (snake snail) & $\begin{array}{l}\text { This was called the snake snail. } \\
\text { Where the name does come from I } \\
\text { have no idea. / They collect the } \\
\text { dew drops. }\end{array}$ & $A, S$ & 14 \\
\hline 20. & 13 & $\begin{array}{l}\text { Helix spp. (*) mainly } \\
\text { Helix pomatia } \\
\text { edible snails }\end{array}$ & csiga, éti csiga (edible snail) & $\begin{array}{l}\text { This is the strongest animal } \\
\text { because it carries its house on the } \\
\text { back. / I would not do any harm } \\
\text { to them, even though they can } \\
\text { make trouble. / I always tread on } \\
\text { them. They like to eat my flowers. I } \\
\text { would throw them back to the } \\
\text { hens. / They are not so harmful. }\end{array}$ & $\mathrm{G}, \mathrm{S}$ & 100 \\
\hline 21. & 13 & $\begin{array}{l}\text { Xerolenta obvia } \\
\text { land snail species }\end{array}$ & csiga, paradicsiga & $\begin{array}{l}\text { These are white little snails on the } \\
\text { plants. They would also stick to the } \\
\text { grass leaves. }\end{array}$ & $G, S$ & 55 \\
\hline 22. & 13 & $\begin{array}{l}\text { Lymnaeidae e.g. } \\
\text { Lymnaea stagnalis } \\
\text { freshwater snail } \\
\text { species }\end{array}$ & vízicsiga (water snail) & $\begin{array}{l}\text { During floods (high water) they } \\
\text { climb on boats or a thick branch. } \\
\text { Floods are coming when the snail } \\
\text { climbs out of the water. }\end{array}$ & W & 6 \\
\hline 23. & 13 & $\begin{array}{l}\text { Planorbidae (excl. } \\
\text { Ferrissia, Ancylus, } \\
\text { Hebetancylus) e.g. } \\
\text { Planorbis planorbis } \\
\text { ramshorn snails }\end{array}$ & csiga, vízicsiga (water snail) & $\begin{array}{l}\text { When the water was rising, this } \\
\text { came up to the surface. }\end{array}$ & W & 12 \\
\hline 24. & 13 & $\begin{array}{l}\text { Bivalvia e.g. } \\
\text { Anodonta cygnea } \\
\text { clams }\end{array}$ & békateknő (frog tub), kagyló & $\begin{array}{l}\text { Frog tub. We would pick them } \\
\text { when I was a kid. It comes off } \\
\text { from the frog. Like the egg from } \\
\text { the inside. }\end{array}$ & W & 83 \\
\hline 25. & 13 & $\begin{array}{l}\text { Gastropoda e.g. } \\
\text { Zebrina detrita } \\
\text { snails }\end{array}$ & csiga & $\begin{array}{l}\text { They would gnaw during the night } \\
\text { and they drag that mucus behind. } \\
\text { / Little snail come out, your house } \\
\text { is burning. You'll get milk and } \\
\text { butter, it will be left for tomorrow. } \\
\text { (a child song) }\end{array}$ & $F, G$ & 100 \\
\hline 26. & 15 & $\begin{array}{l}\text { Julidae e.g. } \\
\text { Megaphyllum } \\
\text { unilineatum } \\
\text { millipede species }\end{array}$ & $\begin{array}{l}\text { ezerlábú (thousand legged), } \\
\text { drótféreg (wire worm) }\end{array}$ & $\begin{array}{l}\text { I have seen this little black insect } \\
\text { on the garbage heap. / Who's got } \\
\text { the patience to pick up so many of } \\
\text { them? They would have swept } \\
\text { them, obviously. }\end{array}$ & $S, G$ & 16 \\
\hline 27. & 15 & $\begin{array}{l}\text { Lithobius spp. e.g. } \\
\text { Lithobius forficatus } \\
\text { common } \\
\text { centipedes }\end{array}$ & százlábú (hundred legged) & $\begin{array}{l}\text { It's so reddish. / You can get many } \\
\text { of them when you lift the flower } \\
\text { pots. }\end{array}$ & $S, G$ & 44 \\
\hline 28. & 9 & $\begin{array}{l}\text { Ixodes spp. e.g. } \\
\text { Ixodes ricinus }\end{array}$ & kullancs, csiglanc & $\begin{array}{l}\text { I think they are not infected here. } \\
\text { They are rather on the blades of }\end{array}$ & $P, F$ & 94 \\
\hline
\end{tabular}


Table 3 Data base of invertebrate folk knowledge among Hungarians (Continued)

ticks

Dermatophagoides

poratka (dust atka)

spp. e.g.

Dermatophagoides

pteronyssinus

house dust mites

30. 9 Sarcoptes scabiei itch mite

rüh [it is not seen as an animal]

31. 9 Sarcoptes suis

rüh pig mange mite

32. 9 Psoroptes ovis

rüh

sheep scrab

33. 9 Pseudoscorpiones e.g. Chelifer

cancroides

false scorpions

34. 8 Araneae e.g.

pók

Tegenaria

domesticaspiders

35. 8 Dolomedes

fimbriatus*

vízipók (water pók)

raft spiders

36. 8 Argyroneta

aquatica*

diving bell spider

37. 8 Araneus spp. e.g. keresztespók (crossed pók) Araneus diadematus spider species

It would creep into your skin and

P little pimples would appear. It would also get wedged in among the fingers. / Something was mixed in pig fat and used as ointment.

grass. It is dangerous because it spreads encephalitis. / You would pick at it or you put fat or oil on it and than it would climb out or fall out. / The one living on animals would not get into humans. / You would say to little kids you're a tick'. I It was not dangerous before. I think this has become infested due to this many poisons and the atom.

$-$

When piglets got the itch, they would be smeared with fat, nowadays with cooking oil.

The Temoxa, we would dip them in summer and then their wool would not fall out.

This is a little beetle, I can see $\mathrm{H}$ them some times. They are like the ones in the TV (scorpions), only they are little. It fell from a tree. It has two feelers.

A wide spread belief says spiders $H$ must not be killed because it brings misfortune.

The same shape as a spider.

It's got a big bladder (in fact, a bubble) with which it goes down.

You put it into a white bag and let G it out in the morning. You would open the bag and it has written your fortune numbers there. / We were afraid of them because they stung. I It is Greek Catholic because it's got a double cross.

This is like a guest spider in these parts. / But it did not eat the common wasp.

You pick its leg out, it would still work for a while, sawing the air. I You get plenty of them in the villages.

Ground spider (that is: not a net weaving species). It has eggs on the back.

You can get yellow ones as well. sits on flowers. 
Table 3 Data base of invertebrate folk knowledge among Hungarians (Continued)

\begin{tabular}{|c|c|c|c|c|c|c|}
\hline & & crab spiders & & & & \\
\hline 42. & 9 & $\begin{array}{l}\text { Dermanyssus } \\
\text { gallinae } \\
\text { poultry mite }\end{array}$ & poloska, pirostetyú (red louse) & $\begin{array}{l}\text { It's there right away in tiny chicks. I } \\
\text { You must roast onions and smear } \\
\text { it under their little wings, at the } \\
\text { tail and the neck. Or, they are } \\
\text { stamped out with smoke. }\end{array}$ & $P$ & 9 \\
\hline 43. & 9 & $\begin{array}{l}\text { Argas reflexus } \\
\text { pigeon tick }\end{array}$ & $\begin{array}{l}\text { madárkullancs (bird tick), vértetü } \\
\text { (blood louse) }\end{array}$ & $\begin{array}{l}\text { It is very quick. If it spreads in } \\
\text { poultry, it would suck their blood, } \\
\text { there is plenty of them. }\end{array}$ & $P$ & 11 \\
\hline 44. & 8 & gossamer & ökörnyál (ox saliva) & $\begin{array}{l}\text { There will be no rain because the } \\
\text { gossamer is stretching (i.e. carried } \\
\text { by the wind). / It usually flies } \\
\text { during Indian summer. }\end{array}$ & G & 16 \\
\hline 45. & 9 & $\begin{array}{l}\text { Parasitidae e.g. } \\
\text { Parasitus } \\
\text { coleoptratorum } \\
\text { a family of } \\
\text { predatory mites }\end{array}$ & poloska & A tiny red bug. & $P$ & 5 \\
\hline 46. & 9 & $\begin{array}{l}\text { Microtrombidium } \\
\text { pusillum } \\
\text { dwarf velvet mite }\end{array}$ & $\begin{array}{l}\text { Istenbárányka (God's lambkin), } \\
\text { Jézusbárányka (Jesus' lambkin) }\end{array}$ & $\begin{array}{l}\text { It's so velvet-like, beautiful, no } \\
\text { dresses like it are ever made. / } \\
\text { They sang: Shine, Sun, shine, Jesus' } \\
\text { lambkin freezes to death under the } \\
\text { gardens. And then the Sun shone. } \\
\text { /You could see it in springtime. }\end{array}$ & $S$ & 17 \\
\hline 47. & 9 & $\begin{array}{l}\text { Tetranychus urticae } \\
\text { red spider mite }\end{array}$ & hamuféreg (ashféreg) & - & A & 4 \\
\hline 48. & 15 & $\begin{array}{l}\text { Astacus astacus*, } \\
\text { Astacus } \\
\text { leptodactylus* } \\
\text { European crayfish, } \\
\text { Danubian crayfish }\end{array}$ & $\begin{array}{l}\text { rák, folyami rák (river rák), cseri } \\
\text { rák (tanned rák) }\end{array}$ & $\begin{array}{l}\text { It's on the water bottom, on } \\
\text { pebbles. / Once upon a time our } \\
\text { canals were so clear, full of crabs. }\end{array}$ & W & 90 \\
\hline 49. & 15 & $\begin{array}{l}\text { Austropotamobius } \\
\text { torrentium } \\
\text { Stone crayfish }\end{array}$ & $\begin{array}{l}\text { sebesvízi rák (rapid waters crab), } \\
\text { rák }\end{array}$ & $\begin{array}{l}\text { This is upstream, in mountain } \\
\text { creeks. / You can't eat it because } \\
\text { it's so tiny. }\end{array}$ & W & 2 \\
\hline 50. & 6 & $\begin{array}{l}\text { Daphnia spp. e.g. } \\
\text { Daphnia magna } \\
\text { water fleas }\end{array}$ & vízibolha (water flea) & Very little, bouncing in water. & W & 2 \\
\hline 51. & 9 & $\begin{array}{l}\text { Argulus foliaceus } \\
\text { common fish louse }\end{array}$ & tetü (louse) & $\begin{array}{l}\text { You can find it in marshy lands. I } \\
\text { Fish ponds were limed. This is why } \\
\text { this bad kind did not occur. }\end{array}$ & W & 10 \\
\hline 52. & 6 & $\begin{array}{l}\text { Oniscidea e.g. } \\
\text { Armadillidium } \\
\text { vulgare } \\
\text { woodlice }\end{array}$ & $\begin{array}{l}\text { pincebogár (cellar bogár), } \\
\text { krumplibogár (potato bogár) }\end{array}$ & $\begin{array}{l}\text { If you touch it, it will become a } \\
\text { ball. / Where there is potato and } \\
\text { the soil is wetter, it would winter } \\
\text { there. }\end{array}$ & $\mathrm{H}$ & 51 \\
\hline 53. & 7 & $\begin{array}{l}\text { Mantis religiosa* } \\
\text { European praying } \\
\text { mantis }\end{array}$ & $\begin{array}{l}\text { imádkozó sáska (praying sáska), } \\
\text { sáska, alázatos manó (humble } \\
\text { imp) }\end{array}$ & $\begin{array}{l}\text { It's hands are like if it would pray, } \\
\text { but it doesn't. / They are usually at } \\
\text { the watersides. / It becomes rare. } \\
\text { Because of the poisons. Mostly it is } \\
\text { encountered on grazing land. / We } \\
\text { mostly have these green ones, but } \\
\text { you could find some brown ones } \\
\text { as well. }\end{array}$ & $\mathrm{A}, \mathrm{O}$ & 42 \\
\hline 54. & 7 & $\begin{array}{l}\text { Acrida hungarica* } \\
\text { Hungarian snouted } \\
\text { grasshopper }\end{array}$ & sáska & $\begin{array}{l}\text { It leaps like magic. / They come in } \\
\text { different colours. }\end{array}$ & $\mathrm{G}, \mathrm{O}$ & 2 \\
\hline 55. & 7 & $\begin{array}{l}\text { Oecanthus pellucens } \\
\text { Italian tree cricket }\end{array}$ & $\begin{array}{l}\text { öszifíreg (Autumn worm) őszike } \\
\text { (little in autumn), haris (roarer) }\end{array}$ & $\begin{array}{l}\text { It says 'gather, gather'. / Autumn is } \\
\text { here, the autumn worm sounds. I } \\
\text { It comes out only in the evening. / } \\
\text { It was brought in on flower vases } \\
\text { on the leaves. }\end{array}$ & $\mathrm{O}$ & 40 \\
\hline 56. & 7 & Locusta migratoria* & siska, sáska, szöcske (hopper) & & A & 11 \\
\hline
\end{tabular}


Table 3 Data base of invertebrate folk knowledge among Hungarians (Continued)

migratory locust

57.

Tettigonia

viridissima

great green bush-

cricket

58.

Dociostaurus

maroccanus

Moroccan locust

59. 7 Calliptamus italicus and similar species Italian locust

60. 7 Chorthippus spp. e.g. Chorthippus parallelus

smaller grasshoppers

61. 7 Gryllus campestris field cricket

62. 7 Acheta domestica house cricket sáska, kabóca, szöcske (hopper)

sáska

szöcske (hopper), sáska

szöcske (hopper), sáska, kabóca meadow. But I don't know the name. / You get green ones,

brown ones.

tücsök, mezei tücsök (meadow tücsök)

tücsök, házi tücsök (house cricket), fehér tücsök (white cricket) (horse drone), csúr, csikóbogár (foal beetle), medve (bear), ollós bogár (scissors beetle) although it does not bite your head off. 1951 for the last time.

They fly. not jump any more when you Then it would be able to jump with the dung-beetle Geotrupes the other one. old peasant houses in the door case. I It likes to come in the it is both warm and damp. I It worms. And the mole eats them
This tiny thing is on the hay

lótetű (horse louse), lóhere

This does not sing, it grazes. It was here long ago, now is gone. I Hay meadows were stripped barren. We collected them.

grows high. I Flies and jumps as well. I It likes to be in the reeds on sedges, weeds. / Haven't seen it for a few years. I It likes to eat leaves, comes in the house. Causes panic,

A bad lot, eats away everything. They fly. / We had them before, in

Black cricket. It is lured out of the hole with a blade of grass. I It can crossed it with your finger. As long as it did not return to the ground. again. I It makes music in summer and does not care with the winter. I It has a kind of wing but light. I They would be in the same hole spp.). I would say it is menial of

Brown-reddish. / Sing in the night. / Well, it leaps, giant leaps. / Long ago it was there in bakeries and in house, crawls to and fro all winter. / Behind the refrigerators, because would loose its colour in the house and sometimes will be quite white by the time it comes out in Spring.

It can be found in manure. / Eats $S$ and worms alike. I It would make big troubles in seedling beds. I It is called louse, but it's not so tiny to be a louse. / Flies in the night. / It has millions of tiny eggs in the nest. / Around Losonc it was called a bear. It resembles it.

Nice beetles. The first one to come S csiribabó, verökőtő, kőverö (stone out in Spring to the sun. / 'They beater), bodobács stick together like the csiribabó (firebugs). / 'They sit out like the verőkőtö.' / Usually on rotten trees.

This kind of bug is in the water, two legs are long. I If the net was any denser, they would eat up

vízibolha (water flea) Notonecta glauca backswimmers (true bugs) 
Table 3 Data base of invertebrate folk knowledge among Hungarians (Continued)

\begin{tabular}{|c|c|c|c|c|c|c|}
\hline & & & & $\begin{array}{l}\text { smaller fish in the apex. / Jumps } \\
\text { and bites. }\end{array}$ & & \\
\hline 66. & 8 & $\begin{array}{l}\text { Gerris spp. e.g. } \\
\text { Gerris paludum } \\
\text { water striders }\end{array}$ & $\begin{array}{l}\text { vízipók (water spider), vízimolnár } \\
\text { (water miller), vízibizigli (paddle } \\
\text { boat) }\end{array}$ & $\begin{array}{l}\text { Collects lesser bugs on the surface } \\
\text { of the water. Very quick. Always on } \\
\text { the top of the water. Maybe it was } \\
\text { called water miller for this reason. } \\
\text { / We also called it paddle boat. } \\
\text { They run in groups. / They can } \\
\text { play on the water very well. }\end{array}$ & W & 58 \\
\hline 67. & 6 & $\begin{array}{l}\text { Dolycoris baccarum } \\
\text { and similar species } \\
\text { sloe bug (true } \\
\text { bugs) }\end{array}$ & $\begin{array}{l}\text { büdösbogár (stink bogár), } \\
\text { büdösbence (stinking Ben), } \\
\text { poloska, büdösmártin (stinking } \\
\text { Martin), büdösbanka (stinky } \\
\text { banka), mezei poloska (meadow } \\
\text { poloska) }\end{array}$ & $\begin{array}{l}\text { Sometimes you snatch it with } \\
\text { raspberries. It's bitter. And very } \\
\text { stinky. / Before cold weather } \\
\text { comes, they are already between } \\
\text { the window panes. They know } \\
\text { winter is coming. }\end{array}$ & $\mathrm{H}, \mathrm{O}$ & 98 \\
\hline 68. & 6 & $\begin{array}{l}\text { Palomena prasina, } \\
\text { Nezara viridula } \\
\text { green shield bug } \\
\text { southern green } \\
\text { stink bug }\end{array}$ & $\begin{array}{l}\text { büdösbogár (stink bogár), } \\
\text { büdösbence (stink Ben), poloska }\end{array}$ & $\begin{array}{l}\text { Do you know, which is green? The } \\
\text { one born this year. By next year it } \\
\text { will be the same colour. This is like } \\
\text { a swan. A young swan is greyish } \\
\text { mottled. }\end{array}$ & $\mathrm{H}, \mathrm{O}$ & 82 \\
\hline 69. & 6 & $\begin{array}{l}\text { Graphosoma } \\
\text { lineatum } \\
\text { Italian striped-bug }\end{array}$ & büdösbogár (stink bogár) & $\begin{array}{l}\text { Lives on dills. Each stem has } 10 \text { or } \\
\text { 15. / They suck out moisture up at } \\
\text { the seeds. I If you only touch any } \\
\text { of them, they are stinky. }\end{array}$ & S & 15 \\
\hline 70. & 6 & $\begin{array}{l}\text { Eurydema ornatum } \\
\text { red cabbage bug }\end{array}$ & $\begin{array}{l}\text { káposztabogár (cabbage bogár), } \\
\text { büdösbogár (stink bogár) }\end{array}$ & $\begin{array}{l}\text { The same smell as [Dolycoris } \\
\text { baccarum]. / Eats cabbage. / } \\
\text { Comes in lots. }\end{array}$ & S & 14 \\
\hline 71. & 6 & $\begin{array}{l}\text { Carabidae e.g. } \\
\text { Zabrus tenebrioides } \\
\text { ground beetles }\end{array}$ & bogár & $\begin{array}{l}\text { They are running about. Here in } \\
\text { the greenhouse. / When the grave } \\
\text { is dug, you would see such black } \\
\text { bugs often in the ground. }\end{array}$ & $\mathrm{H}$ & 42 \\
\hline 72. & 6 & $\begin{array}{l}\text { Geotrupes spp. e.g. } \\
\text { Geotrupes vernalis } \\
\text { dor beetles }\end{array}$ & ganajtúró (dung grouter) & $\begin{array}{l}\text { Grouts in cow dung. } \\
\text { Undemanding beast. / Makes } \\
\text { pellets and rolls them. / There were } \\
\text { millions. Today only now and then. }\end{array}$ & S & 53 \\
\hline 73. & 6 & $\begin{array}{l}\text { Melasoma populi } \\
\text { poplar leaf beetle }\end{array}$ & no name & $\begin{array}{l}\text { It would come on poplars in the } \\
\text { woods. Crawls on leaves. }\end{array}$ & $\mathrm{F}$ & 4 \\
\hline 74. & 6 & $\begin{array}{l}\text { Phytodecta rufipes } \\
\text { brassy willow leaf } \\
\text { beetle }\end{array}$ & $\begin{array}{l}\text { ötpettyes katicabogár (five spots } \\
\text { Kate bogár), katicabogár (Kate } \\
\text { bogár) }\end{array}$ & $\begin{array}{l}\text { It is lighter, yellowish-red, five spots. } \\
\text { Gnawed sown Trifolium away. / A } \\
\text { pest in parcels under lucerne. }\end{array}$ & A & 4 \\
\hline 75. & 6 & $\begin{array}{l}\text { Leptinotarsa } \\
\text { decemlineata } \\
\text { Colorado potato } \\
\text { beetle }\end{array}$ & $\begin{array}{l}\text { krumplibogár (potato bogár), } \\
\text { mandalinka, kolorádóbogár } \\
\text { (Colorado bogár), kórórágó } \\
\text { (stalk gnawer), pizsamás bogár } \\
\text { (pijama bogár) }\end{array}$ & $\begin{array}{l}\text { This is what we got from America. } \\
\text { / You must put nettle in water and } \\
\text { leave it for week. It will become } \\
\text { stinky and sprays the plant. / You } \\
\text { could get paid if you found such } \\
\text { bugs. I It was introduced with the } \\
\text { potato. / Just now there are not so } \\
\text { many. It rained a lot. }\end{array}$ & $A$ & 100 \\
\hline 76. & 6 & $\begin{array}{l}\text { Chaetocnema spp. } \\
\text { and Phyllotrema } \\
\text { spp. e.g. } \\
\text { Chaetocnema } \\
\text { tibialis } \\
\text { flea beetles }\end{array}$ & $\begin{array}{l}\text { balha, káposztabolha (cabbage } \\
\text { bolha) }\end{array}$ & $\begin{array}{l}\text { It jumps. Makes holes in radish, } \\
\text { kohlrabi leaves, cabbage. / Tiny } \\
\text { black bugs. }\end{array}$ & A & 61 \\
\hline 77. & 6 & $\begin{array}{l}\text { Chaetocnema spp. } \\
\text { and Phyllotrema } \\
\text { spp. (+Erwinia } \\
\text { stewartii) } \\
\text { flea beetles and } \\
\text { Stewart's wilt }\end{array}$ & balha, bogár & $\begin{array}{l}\text { Tiny black bugs, leaves long marks } \\
\text { on the greenish part of maize. I } \\
\text { Sucks the leaves, likes sweet corn } \\
\text { best. }\end{array}$ & $A$ & 4 \\
\hline 78. & 6 & $\begin{array}{l}\text { Epicometis hirta } \\
\text { hairy beetle }\end{array}$ & $\begin{array}{l}\text { szörös kandalló (hairy hearth), } \\
\text { bogár }\end{array}$ & & $A$ & 11 \\
\hline
\end{tabular}


Table 3 Data base of invertebrate folk knowledge among Hungarians (Continued)

\begin{tabular}{|c|c|c|c|c|c|c|}
\hline & & & & $\begin{array}{l}\text { Hairy. / Comes on flowers. There } \\
\text { are many, in particular on the } \\
\text { fields, sunflowers and wheat. }\end{array}$ & & \\
\hline 79. & 6 & $\begin{array}{l}\text { Tenebrio molitor } \\
\text { mealworm beetle }\end{array}$ & $\begin{array}{l}\text { drótkukac (wire worm), } \\
\text { lisztkukac (flour worm) }\end{array}$ & $\begin{array}{l}\text { I bought corn meal in the shop } \\
\text { and it was full with it. / It also } \\
\text { breeds in ground pepper. / You } \\
\text { had better screen the flour before } \\
\text { use. }\end{array}$ & $\mathrm{H}$ & 14 \\
\hline 80. & 6 & $\begin{array}{l}\text { Curculionidae e.g. } \\
\text { Larinus turbinatus } \\
\text { true weevils }\end{array}$ & orrúbogár (nosy bug) & $\begin{array}{l}\text { It has a long trunk. / The wings } \\
\text { are hard. }\end{array}$ & $A$ & 10 \\
\hline 81. & 6 & $\begin{array}{l}\text { Anthonomus } \\
\text { pomorum } \\
\text { apple blossom } \\
\text { weevil }\end{array}$ & $\begin{array}{l}\text { bimbólikasztó (bud puncher), } \\
\text { bimbólikasztó bogár (bud } \\
\text { puncher bogár), }\end{array}$ & $\begin{array}{l}\text { A tiny bug, gets into the buds } \\
\text { when it starts to sprout and does } \\
\text { harm to cherries, plums. }\end{array}$ & $\mathrm{O}$ & 19 \\
\hline 82. & 6 & $\begin{array}{l}\text { Cleonus } \\
\text { punctiventris } \\
\text { sugar-beet weevil }\end{array}$ & répabogár (beet bogár) & $\begin{array}{l}\text { Carrot beetle. Gnaws a hole in the } \\
\text { carrot. Sucks the sap of tiny carrots } \\
\text { and they perish, wither. This is why } \\
\text { it was controlled by spraying. }\end{array}$ & $A$ & 2 \\
\hline 83. & 6 & $\begin{array}{l}\text { Ceuthorrhynchus } \\
\text { macula-alba } \\
\text { poppy } \\
\text { ceutorrhynchid } \\
\text { beetle }\end{array}$ & mákbogár (poppy bogár) & $\begin{array}{l}\text { Punches poppy heads while young. } \\
\text { And it would not yield because the } \\
\text { worms eat it away from inside. }\end{array}$ & A & 2 \\
\hline 84. & 6 & $\begin{array}{l}\text { Sitophilus granarius } \\
\text { wheat weevil }\end{array}$ & $\begin{array}{l}\text { zsúzsok, búzazsúzsok (wheat } \\
\text { zsúzsok) }\end{array}$ & $\begin{array}{l}\text { It is also a bad lot, eats the wheat. } \\
\text { / Does harm to fodder inside. / If } \\
\text { there is only a little water, it would } \\
\text { grow. }\end{array}$ & $\mathrm{H}$ & 22 \\
\hline 85. & 6 & $\begin{array}{l}\text { Bruchus pisi, } \\
\text { Acanthoscelides } \\
\text { obtectus } \\
\text { pea beetle, bean } \\
\text { beetle }\end{array}$ & $\begin{array}{l}\text { zsúzsok, paszulyzsúzsok (bean } \\
\text { zsúzsok) }\end{array}$ & $\begin{array}{l}\text { Comes from inside the peas. I } \\
\text { More recently you can find in } \\
\text { beans as well. / All beans must be } \\
\text { discarded. Eats the cotyledon out. }\end{array}$ & $\mathrm{H}$ & 58 \\
\hline 86. & 6 & $\begin{array}{l}\text { Lytta vesicatoria } \\
\text { Spanish fly }\end{array}$ & kőrisbogár (ashtree bogár) & $\begin{array}{l}\text { My grandmother would say, rain is } \\
\text { coming the ash tree stinks. / Very } \\
\text { stinky, in particular on the ash tree. }\end{array}$ & $F, G$ & 88 \\
\hline 87. & 6 & $\begin{array}{l}\text { Cantharidae e.g. } \\
\text { Rhagonycha fulva } \\
\text { soldier beetles }\end{array}$ & kőrisbogár (ashtree bogár) & - & $F, G$ & 7 \\
\hline 88. & $\begin{array}{l}6 \\
10\end{array}$ & $\begin{array}{l}\text { Melolontha } \\
\text { melolontha } \\
\text { cockchafer }\end{array}$ & $\begin{array}{l}\text { cserebogár, májusi cserebogár } \\
\text { (May cserebogár), pajod, } \\
\text { csimmaz, pillangó (butterfly) }\end{array}$ & $\begin{array}{l}\text { You can get cockchafer in Spring. } \\
\text { Not later. / You need three years } \\
\text { before it develops. / If there is a lot } \\
\text { of cockchafers, you will get high } \\
\text { corn yields. / Cockchafer would lay } \\
\text { (give birth to) that white butterfly. }\end{array}$ & $\mathrm{O}$ & 100 \\
\hline 89. & 6 & $\begin{array}{l}\text { Amphimallon } \\
\text { solstitialis } \\
\text { summer chafer }\end{array}$ & $\begin{array}{l}\text { cserebogár, kis cserebogár (small } \\
\text { cserebogár) }\end{array}$ & $\begin{array}{l}\text { It comes later on, in June, mostly } \\
\text { (as opposed to the ordinary } \\
\text { cockchafer). / This is lesser and } \\
\text { yellowish. }\end{array}$ & $\mathrm{O}$ & 5 \\
\hline 90. & 6 & $\begin{array}{l}\text { Cerambyx cerdo } \\
\text { great capricorn } \\
\text { beetle* }\end{array}$ & cincér, hőscincér (hero cincér) & $\begin{array}{l}\text { It can weep like hell when you get } \\
\text { it. / Got large moustache and long } \\
\text { legs. / 'Your moustache is like that } \\
\text { of a capricorn beetle.' }\end{array}$ & $\mathrm{S}, \mathrm{F}$ & 33 \\
\hline 91. & 6 & $\begin{array}{l}\text { Rosalia alpina* } \\
\text { Rosalia longicorn }\end{array}$ & cincér & - & $\mathrm{F}$ & 2 \\
\hline 92. & 6 & $\begin{array}{l}\text { Pyrrhidium } \\
\text { sanguineum } \\
\text { Welsh oak } \\
\text { longhorn beetle }\end{array}$ & kőrisbogár (ashtree bogár) & - & $\mathrm{s}$ & 4 \\
\hline 93. & 6 & $\begin{array}{l}\text { Lucanus cervus* } \\
\text { stag beetle }\end{array}$ & & $\begin{array}{l}\text { Once you catch it, it would grasp } \\
\text { your finger like a pair of scissors. }\end{array}$ & $\mathrm{F}$ & 98 \\
\hline
\end{tabular}


Table 3 Data base of invertebrate folk knowledge among Hungarians (Continued)

\begin{tabular}{|c|c|c|c|c|c|c|}
\hline & & & $\begin{array}{l}\text { szarvasbogár (horn bogár), } \\
\text { csikkantós bogár (pinching } \\
\text { bogár), bika, tehén (bull, cow) }\end{array}$ & $\begin{array}{l}\text { We would nail it on the wall, the } \\
\text { kids just gazed. I This is the bull } \\
\text { (male), and this is the cow } \\
\text { (female). / They wrestle. Two bulls. } \\
\text { / It comes mostly around oak } \\
\text { trees. }\end{array}$ & & \\
\hline 94. & 6 & $\begin{array}{l}\text { Oryctes nasicornis* } \\
\text { European } \\
\text { rhinoceros beetle }\end{array}$ & $\begin{array}{l}\text { orrszarvúbogár (nose horn } \\
\text { bogár), orrszarvú (nose horn), } \\
\text { szarvasbogár (horn bogár) }\end{array}$ & $\begin{array}{l}\text { You can't get it everywhere. / They } \\
\text { like old trees. / A kind of horn } \\
\text { beetle. }\end{array}$ & $F, S$ & 61 \\
\hline 95. & 6 & $\begin{array}{l}\text { Lethrus apterus* } \\
\text { flightless earth- } \\
\text { boring dung beetle }\end{array}$ & bogár & $\begin{array}{l}\text { This bores holes in the ground and } \\
\text { drags in leaves in reserve gear. }\end{array}$ & G & 2 \\
\hline 96. & 6 & $\begin{array}{l}\text { Pentodon idiota } \\
\text { beetle species }\end{array}$ & bogár & $\begin{array}{l}\text { This is in springtime. Those big } \\
\text { ones on the sidewalk. }\end{array}$ & $S$ & 4 \\
\hline 97. & 6 & $\begin{array}{l}\text { Coccinella } \\
\text { septempunctata } \\
\text { seven-spot ladybird }\end{array}$ & $\begin{array}{l}\text { katicabogár (Kate bogár), } \\
\text { hétpettyes katicabogár (seven } \\
\text { spots Kate bogár), petikebogár } \\
\text { (Pete bogár) }\end{array}$ & $\begin{array}{l}\text { It eats aphids. It seems it likes } \\
\text { them. / 'Kate beetle! Where I go to } \\
\text { marry?' And then we watched. } \\
\text { Blew at it till it flew away. That } \\
\text { way we married. }\end{array}$ & $S, G$ & 100 \\
\hline 98. & 6 & $\begin{array}{l}\text { Adalia bipunctata } \\
\text { two-spot ladybird }\end{array}$ & $\begin{array}{l}\text { katicabogár (Kate bogár), } \\
\text { petikebogárka (little Pete bogár) }\end{array}$ & $\begin{array}{l}\text { Similar to Kate beetle, but has only } \\
\text { two spots, unfortunately. }\end{array}$ & $\mathrm{S}, \mathrm{G}$ & 12 \\
\hline 99. & 6 & $\begin{array}{l}\text { Psyllobora } \\
\text { vigintiduopunctata } \\
\text { 22-spot ladybird }\end{array}$ & $\begin{array}{l}\text { katicabogár (Kate bogár), sárga } \\
\text { katicabogár (yellow Kate bogár), } \\
11 \text { pettyű katica (11 spots Kate) }\end{array}$ & $\begin{array}{l}\text { There are yellow Kate beetles as } \\
\text { well. }\end{array}$ & $S, G$ & 68 \\
\hline 100. & 6 & $\begin{array}{l}\text { Harmonia axyridis } \\
\text { harlequin ladybird }\end{array}$ & katicabogár (Kate bogár) & $\begin{array}{l}\text { There was such a Kate beetle } \\
\text { invasion last year. They are not the } \\
\text { ones I saw when I was a kid. I The } \\
\text { Sun shone there in a warm } \\
\text { afternoon, there were so many you } \\
\text { could grasp them. }\end{array}$ & $H$ & 71 \\
\hline 101. & 6 & $\begin{array}{l}\text { Meloe spp. e.g. } \\
\text { Meloe } \\
\text { proscarabaeus }\left(^{*}\right) \\
\text { oil beetles }\end{array}$ & bogár & It's got a big belly like this. & $F, A$ & 11 \\
\hline 102. & 6 & $\begin{array}{l}\text { Calosoma } \\
\text { sycophanta* } \\
\text { forest caterpillar } \\
\text { hunter }\end{array}$ & bogár & $\begin{array}{l}\text { Usually it is on the ground as well. } \\
\text { When we get home, it sneezes. } \\
\text { You are not hit by what it blows } \\
\text { out. Maybe only a little air. Protects } \\
\text { itself. / Runs away quickly. }\end{array}$ & $F$ & 7 \\
\hline 103. & 6 & $\begin{array}{l}\text { Gyrinidae e.g. } \\
\text { Gyrinus natator } \\
\text { whirligig beetles }\end{array}$ & bogár & - & W & 4 \\
\hline 104. & 6 & $\begin{array}{l}\text { Dytiscus spp. e.g. } \\
\text { Dytiscus marginalis } \\
\text { great diver species }\end{array}$ & vízibogár (water bogár) & - & W & 4 \\
\hline 105. & 6 & $\begin{array}{l}\text { Hydrous piceus } \\
\text { great silver water } \\
\text { beetle }\end{array}$ & $\begin{array}{l}\text { vízibogár (water bogár), csíbor } \\
\text { (pincher), vízibölény (water } \\
\text { buffalo) }\end{array}$ & $\begin{array}{l}\text { Big and black, likes warm water. I } \\
\text { Mostly in lakes. / Sets on the fish, } \\
\text { gnaws on it. / They say it bites. I } \\
\text { When it ebbed, they flew here to } \\
\text { the light. }\end{array}$ & W & 79 \\
\hline 106. & 6 & $\begin{array}{l}\text { Cetonia aurata } \\
\text { green rose chafer }\end{array}$ & $\begin{array}{l}\text { szentjánosbogár (Saint John's } \\
\text { bogár), foszforbogár } \\
\text { (phosphorus bogár), aranyos } \\
\text { virágbogár (golden flower } \\
\text { bogár) }\end{array}$ & $\begin{array}{l}\text { All say glow worm because it } \\
\text { shines as the Sun hits it. But this } \\
\text { can not be seen in the night. I } \\
\text { Flies with a buzz. Creeps into } \\
\text { drying cloth. }\end{array}$ & $\mathrm{G}$ & 82 \\
\hline 107. & 6 & $\begin{array}{l}\text { Lampyris noctiluca, } \\
\text { Lamprohiza } \\
\text { splendidula } \\
\text { common glow- } \\
\text { worm, Central } \\
\text { European firefly }\end{array}$ & $\begin{array}{l}\text { szentjánosbogár (Saint John's } \\
\text { bogár), foszforbogár } \\
\text { (phosphorus bogár) }\end{array}$ & $\begin{array}{l}\text { They are tiny and light up. You } \\
\text { can see in the night air. I It's only } \\
\text { a small worm. I would illuminate } \\
\text { when the [Oecanthus pellucens] } \\
\text { sounds. The back is lighting. }\end{array}$ & G & 69 \\
\hline
\end{tabular}


Table 3 Data base of invertebrate folk knowledge among Hungarians (Continued)

\begin{tabular}{|c|c|c|c|c|c|c|}
\hline 108. & 6 & $\begin{array}{l}\text { Ips spp. e.g. Ips } \\
\text { typographus } \\
\text { engraver beetles }\end{array}$ & szu, szujétel, faszu (wood szu) & $\begin{array}{l}\text { It makes very small holes, tiny } \\
\text { dense holes. I I would put firewood } \\
\text { in tin trays to keep it from the } \\
\text { parquet. }\end{array}$ & $\mathrm{H}$ & 100 \\
\hline 109. & 6 & $\begin{array}{l}\text { Agriotes spp. e.g. } \\
\text { Agriotes sputator } \\
\text { click beetles }\end{array}$ & $\begin{array}{l}\text { drótkukac (wire kukac), } \\
\text { drótbogár (wire bogár), drótféreg } \\
\text { (wire féreg) }\end{array}$ & Likes carrots. Yellowish, hardy. & $\mathrm{H}$ & 27 \\
\hline 110. & 6 & $\begin{array}{l}\text { Diabrotica virgifera } \\
\text { Western corn } \\
\text { rootworm }\end{array}$ & kukoricabogár (corn bogár) & $\begin{array}{l}\text { Can make a lot of harm. Sucks the } \\
\text { sap of the leaves. }\end{array}$ & A & 2 \\
\hline 111. & 6 & $\begin{array}{l}\text { Blaps spp. e.g. Blaps } \\
\text { lethifera } \\
\text { tenebrionid beetle }\end{array}$ & $\begin{array}{l}\text { büdösbogár (stink bogár), } \\
\text { büdösbanka (stinky banka), } \\
\text { kátránybogár (tar bogár), } \\
\text { svábbogár (Swabian bogár) }\end{array}$ & $\begin{array}{l}\text { Very stinky when you step on it. / } \\
\text { Mostly in cellars. Formerly tar } \\
\text { paper was put down in dirt floored } \\
\text { houses and it was underneath. }\end{array}$ & $\mathrm{H}$ & 33 \\
\hline 112. & 4 & $\begin{array}{l}\text { Xylocopa violacea, } \\
\text { Xylocopa valga } \\
\text { black colored } \\
\text { carpenter bees }\end{array}$ & $\begin{array}{l}\text { dongó (buzzer), cigánydongó } \\
\text { (Gypsy buzzer) }\end{array}$ & $\begin{array}{l}\text { Big, black and collects honey also. } \\
\text { Bites. Has a loud buzz. / Does not } \\
\text { bite. / I've got a barn full of wood. } \\
\text { They drill on them like drilling } \\
\text { machines. It laid eggs into it. }\end{array}$ & $S$ & 53 \\
\hline 113. & 4 & $\begin{array}{l}\text { Apis mellifera } \\
\text { European honey } \\
\text { bee }\end{array}$ & $\begin{array}{l}\text { méh, méhecske (little méh), házi } \\
\text { méh (house méh) }\end{array}$ & $\begin{array}{l}\text { It was August when there is less } \\
\text { flowers and these times bees are } \\
\text { more dangerous, attack you easier. }\end{array}$ & $\mathrm{O}$ & 100 \\
\hline 114. & 4 & $\begin{array}{l}\text { Apis mellifera var. } \\
\text { ligustica } \\
\text { Italian bee }\end{array}$ & $\begin{array}{l}\text { vadméh (wild méh), erdei méh } \\
\text { (forest méh) }\end{array}$ & $\begin{array}{l}\text { It was an old house, full of wild } \\
\text { bees in the end. They sting, its } \\
\text { painful. / We call them forest bee. } \\
\text { Once we brought some home with } \\
\text { my father. Ants attacked and killed } \\
\text { them off. / They make hives in } \\
\text { hollows. / The tree brings that wax. } \\
\text { And they eat it. }\end{array}$ & $G, F$ & 31 \\
\hline 115. & 4 & $\begin{array}{l}\text { Osmia adunca } \\
\text { mason bee species }\end{array}$ & nádiméh (reed méh) & $\begin{array}{l}\text { It can nest in a single stem of reed, } \\
\text { but can go up to the first node } \\
\text { only. / They do not bring in honey, } \\
\text { but pollens, and they put a lid on } \\
\text { it made of mud, which is gnawed } \\
\text { away by the young when they } \\
\text { come out of it. }\end{array}$ & $\mathrm{H}$ & 18 \\
\hline 116. & 4 & $\begin{array}{l}\text { Andrenidae e.g. } \\
\text { Andrena flavipes } \\
\text { mining bees }\end{array}$ & csemelyke, vadméhe (wild méh) & $\begin{array}{l}\text { It is in the ground. Such brownish } \\
\text { in colour. Collects nectar, pollen. } \\
\text { Tiny. / Leaves little heaps around } \\
\text { with a hole in the middle. It does } \\
\text { not have a strong sting but it does } \\
\text { sting. It's got a net but not so } \\
\text { beautiful which is built by the } \\
\text { common wasp. }\end{array}$ & G & 15 \\
\hline 117. & 4 & $\begin{array}{l}\text { Bombus terrestris } \\
\text { buff-tailed } \\
\text { bumblebee }\end{array}$ & $\begin{array}{l}\text { dongó (buzzer), csemélyke, } \\
\text { földiméh (ground méh) }\end{array}$ & $\begin{array}{l}\text { Hairy. They dwell in the ground. } \\
\text { Don't do any harm to man. Collect } \\
\text { honey as well. / Maybe there is a } \\
\text { yellowish stripe in the back on top. } \\
\text { / Like my finger - they make little } \\
\text { round nests to put honey in it for } \\
\text { themselves. Foxes, dogs, mice rake } \\
\text { it out and eat. }\end{array}$ & $\mathrm{G}, \mathrm{O}$ & 25 \\
\hline 118. & 4 & $\begin{array}{l}\text { Bombus lapidarius } \\
\text { red-tailed } \\
\text { bumblebee }\end{array}$ & dongó (buzzer) & $\begin{array}{l}\text { It does not die as the other bee } \\
\text { which has the sting coming out. } \\
\text { This one does not tear its sting off, } \\
\text { it merely stings you. / Such a big } \\
\text { black with red and yellow head. }\end{array}$ & $\mathrm{G}, \mathrm{O}$ & 7 \\
\hline 119. & 11 & $\begin{array}{l}\text { Formica rufa* } \\
\text { red wood ant }\end{array}$ & $\begin{array}{l}\text { vöröshangya (red hangya), erdei } \\
\text { vöröshangya (forest red hangya) }\end{array}$ & $\begin{array}{l}\text { Where there is this big ant, it } \\
\text { makes a big ant hill. If you poke it } \\
\text { millions come out, but they are all } \\
\text { alike. }\end{array}$ & $\mathrm{F}$ & 14 \\
\hline
\end{tabular}


Table 3 Data base of invertebrate folk knowledge among Hungarians (Continued)

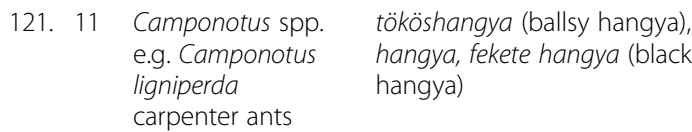

\begin{tabular}{|c|c|c|}
\hline & $\begin{array}{l}\text { ant casts with } \\
\text { wings }\end{array}$ & $\begin{array}{l}\text { szárnyashangya (winged } \\
\text { hangya) }\end{array}$ \\
\hline 121. 11 & $\begin{array}{l}\text { Camponotus spp. } \\
\text { e.g. Camponotus } \\
\text { ligniperda } \\
\text { carpenter ants }\end{array}$ & $\begin{array}{l}\text { tököshangya (ballsy hangya) } \\
\text { hangya, fekete hangya (blac } \\
\text { hangya) }\end{array}$ \\
\hline
\end{tabular}

\begin{tabular}{|c|c|c|}
\hline 122. 11 & $\begin{array}{l}\text { Lasius flavus, } L . \\
\text { umbratus } \\
\text { yellow meadow ant }\end{array}$ & sárga hangya (yellow hangy \\
\hline 23. 11 & $\begin{array}{l}\text { Temnothorax spp. } \\
\text { e.g. Temnothorax } \\
\text { affinis } \\
\text { ant species }\end{array}$ & hangya \\
\hline 124.11 & $\begin{array}{l}\text { Tetramorium } \\
\text { caespitum and } \\
\text { similar ant species }\end{array}$ & $\begin{array}{l}\text { hangya, fekete hangya (black } \\
\text { hangya) }\end{array}$ \\
\hline 125. 4 & $\begin{array}{l}\text { Sceliphron } \\
\text { destillatorium } \\
\text { mud dauber wasp }\end{array}$ & $\begin{array}{l}\text { darázs, szalmadarázs (straw } \\
\text { darázs) }\end{array}$ \\
\hline 126. 4 & $\begin{array}{l}\text { Sphecidae e.g. } \\
\text { Ammophila } \\
\text { sabulosa } \\
\text { digger wasps }\end{array}$ & földidarázs (ground darázs) \\
\hline 127. 4 & $\begin{array}{l}\text { Vespa crabro } \\
\text { European hornet }\end{array}$ & lódarázs (horse darázs) \\
\hline
\end{tabular}
$\begin{array}{rll}\text { 128. } 4 \text { Vespula vulgaris, } & \text { kecskedarázs (goat darázs), } \\ & \text { Polistes gallicus } & \text { darázs, házi darázs (house } \\ \text { paper wasp species } & \text { darázs), padlási darázs (attic }\end{array}$ darázs)
It drills the ground and then
billions fly around in the air. / It
comes out from the parquet in the
apartment. / We would say if the
winged ant comes out, it will rain.

They gnaw at trees. / We could

not stay there under the walnut

tree (sitting, talking) there were so

many. I put salt on their way and

later I could see that they move

away. Now see, that one came

back, just like talking something to

the others and they queue up and

move out. I say, cunning beasts,

they are. That one was the officer,

who commanded. I It's ballsy

because it carries the eggs between

the legs like a big squash. II

brought into the flat with the

wood.

That one is yellow, bites like hell. / A

Like the poppy seeds, so tiny they

are.

Galls grow on oak trees. Some kind F of tiny ants are fond of living in them. They make a little hole in it where they can get through. They would thrive on the gall.

There are so many in the garden it $\mathrm{S}$ is like a miracle. They climb on our legs but do not bite so hard. Tiny black bits.

Makes nest of mud on the rafter. I S It's long and thin.

Drills a hole in the sand. Come G and go in it.

That one is dangerous. Some 5-6 F bite you, you may die. / We say, if nine horse wasps bite the horse, it will perish. I It made a 12 storey nest, hanging on the wall. / You had to pee on the ground and smear the mud over it (the bite). I Many are allergic when bitten. It would not die after biting. Goes on, bites again.

My whole head was swollen. I was S a kid, the old women gathered around, some brought sour cream, this or that. I was smeared over, embalmed. Next day I was okay. / Likes mainly the attic. / The mother survives in winter and then there are many in summer. / Aphid appear on the young upper leaves of the peach tree, then the wasp comes but they do not do any harm to the lice I think they eat what the aphid produce.

They put fire above the nest, they were poured over with hot water, 
Table 3 Data base of invertebrate folk knowledge among Hungarians (Continued)

\begin{tabular}{|c|c|c|c|c|c|}
\hline & German wasp & & $\begin{array}{l}\text { put chemicals on it. / It had a tiny } \\
\text { hole like this. They would keep on } \\
\text { coming and going there and built } \\
\text { a beautiful honeycomb. }\end{array}$ & & \\
\hline 130. 15 & $\begin{array}{l}\text { Cynips quercusfolii } \\
\text { gall wasp species }\end{array}$ & cseregolyó (oak ball), gubacs & $\begin{array}{l}\text { This is not the fruit of the tree, it is } \\
\text { on the leaves. On oak trees. / There } \\
\text { is some bug in this ball as well. } \\
\text { Hatches from it. }\end{array}$ & $\mathrm{F}$ & 37 \\
\hline 131. 15 & $\begin{array}{l}\text { Rhodites rosae } \\
\text { mossy rose gall } \\
\text { wasp }\end{array}$ & $\begin{array}{l}\text { gubics, hamufíreg (ash worm), } \\
\text { macskatöki (cat's bollocks), } \\
\text { csipkelabda (rose hips ball) }\end{array}$ & $\begin{array}{l}\text { It's on briars. I saw it on roses. } \\
\text { Good for nothing like the balls of a } \\
\text { cat. }\end{array}$ & G & 11 \\
\hline 132. 15 & $\begin{array}{l}\text { Andricus hungaricus } \\
\text { Hungarian gall } \\
\text { wasp }\end{array}$ & gubacs (gall), gubics (gall) & $\begin{array}{l}\text { My mother made us thrown them } \\
\text { away. You must not keep it (at the } \\
\text { house) because brood will not } \\
\text { hatch the eggs. }\end{array}$ & $\mathrm{F}$ & 83 \\
\hline 133. 14 & $\begin{array}{l}\text { Acherontia atropos* } \\
\text { Death's-head hawk } \\
\text { moth }\end{array}$ & $\begin{array}{l}\text { ördögpillangó (devil's pillangó), } \\
\text { boszorkánylepke (witch lepke), } \\
\text { halállepke (death lepke), } \\
\text { halálfejes lepke (death's head } \\
\text { lepke) }\end{array}$ & $\begin{array}{l}\text { Quite big. A pest. / Big and ugly } \\
\text { like the devil. / They say it was a } \\
\text { witch butterfly, but this is wrong. } \\
\text { Some old bitches made it up. I } \\
\text { Comes in the evening and flies } \\
\text { around here. I It has a big death's } \\
\text { head. }\end{array}$ & $\mathrm{S}$ & 77 \\
\hline 134. 14 & $\begin{array}{l}\text { Macroglossum } \\
\text { stellatarum } \\
\text { hummingbird } \\
\text { hawk-moth }\end{array}$ & $\begin{array}{l}\text { lepke, kocsisirma (carman Irma), } \\
\text { kolibri (hummingbird) }\end{array}$ & $\begin{array}{l}\text { Has a long tongue reaching in } \\
\text { every flower. / Is like a } \\
\text { hummingbird. / Make noises with } \\
\text { the wings. }\end{array}$ & S & 36 \\
\hline 135. 14 & $\begin{array}{l}\text { Lepidoptera e.g. } \\
\text { Melitaea athalia } \\
\text { butterflies }\end{array}$ & lepke, pillangó, hernyó & $\begin{array}{l}\text { Not a real pest. We were glad to } \\
\text { see them long ago. They are very } \\
\text { nice. }\end{array}$ & G & 100 \\
\hline 136. 14 & $\begin{array}{l}\text { Ephestia kuehniella } \\
\text { Mediterranean flour } \\
\text { moth }\end{array}$ & moly & $\begin{array}{l}\text { A little worm. When you screen the } \\
\text { flour, it's like a spider web, woven } \\
\text { in. Flour gets the moth when you } \\
\text { keep it long, let's say a year. }\end{array}$ & $\mathrm{H}$ & 7 \\
\hline 137. 10 & $\begin{array}{l}\text { Coccyx turionella } \\
\text { pine bud moth }\end{array}$ & rügyfúró (bud driller) & $\begin{array}{l}\text { They can make big damage when } \\
\text { they are many. Does harm to } \\
\text { cherry trees in springtime mostly. } \\
\text { This is long like this, has a bill, it } \\
\text { punches the plants with. }\end{array}$ & $\mathrm{O}$ & 2 \\
\hline 138. 10 & $\begin{array}{l}\text { Cydia pomonella, } \\
\text { Anarsia lineatella } \\
\text { codling moth, } \\
\text { peach twig borer }\end{array}$ & kukac, hernyó & $\begin{array}{l}\text { Moth larvae are called worms here. } \\
\text { Likes to take a place in quince. }\end{array}$ & $\mathrm{O}$ & 9 \\
\hline 139. 14 & $\begin{array}{l}\text { Inachis io* } \\
\text { European peacock } \\
\text { butterfly }\end{array}$ & $\begin{array}{l}\text { pávaszemes lepke (peackock } \\
\text { lepke), pávaszem (peackock's } \\
\text { eye) }\end{array}$ & $\begin{array}{l}\text { If you see a red one first in the } \\
\text { new year, you will remain healthy } \\
\text { and fall in love. }\end{array}$ & G & 9 \\
\hline 140. 14 & $\begin{array}{l}\text { Vanessa atalanta* } \\
\text { red admiral }\end{array}$ & lepke & - & $\mathrm{O}$ & 2 \\
\hline 141. 14 & $\begin{array}{l}\text { Vanessa cardui } \\
\text { painted lady }\end{array}$ & lepke & $\begin{array}{l}\text { It was like this which came from } \\
\text { Africa (heard on the radio). And } \\
\text { next year I saw two or three but } \\
\text { never again. Maybe it would not } \\
\text { find food to stay. }\end{array}$ & $\mathrm{O}$ & 2 \\
\hline 142. 14 & $\begin{array}{l}\text { Gonepteryx rhamni } \\
\text { common } \\
\text { brimstone }\end{array}$ & $\begin{array}{l}\text { sárga lepke (yellow lepke), sárga } \\
\text { pille }\end{array}$ & $\begin{array}{l}\text { If you see a yellow butterfly first in } \\
\text { spring, you'll fall ill. }\end{array}$ & G & 7 \\
\hline 143. 14 & $\begin{array}{l}\text { Pieris brassicae } \\
\text { large white }\end{array}$ & $\begin{array}{l}\text { káposztalepke (cabbage lepke), } \\
\text { lepke, fehér lepke (white lepke) }\end{array}$ & $\begin{array}{l}\text { Lays eggs on the cabbage and a } \\
\text { little green worm comes out of it. / } \\
\text { Its wings are white and there are } \\
\text { plenty. Cockchafers lay its worm. } \\
\text { You say when there are many } \\
\text { cockchafers, there is plenty of } \\
\text { worms on the trees. }\end{array}$ & A & 86 \\
\hline
\end{tabular}


Table 3 Data base of invertebrate folk knowledge among Hungarians (Continued)

\begin{tabular}{|c|c|c|c|c|c|c|}
\hline 144. & 14 & $\begin{array}{l}\text { Polyommatus spp. } \\
\text { e.g. Polyommatus } \\
\text { icarus } \\
\text { blues (butterfly } \\
\text { species) }\end{array}$ & $\begin{array}{l}\text { lepke, pillangó, kék pillangó (blue } \\
\text { pillangó) }\end{array}$ & $\begin{array}{l}\text { After the rain these white } \\
\text { butterflies are in the edges of } \\
\text { puddles. As many can get to it. I } \\
\text { Bluish grey. It was small. }\end{array}$ & G & 31 \\
\hline 145. & 14 & $\begin{array}{l}\text { Mamestra brassicae } \\
\text { cabbage moth }\end{array}$ & $\begin{array}{l}\text { bagolylepke (owl lepke), éjjeli } \\
\text { pille (nocturnal pille) }\end{array}$ & $\begin{array}{l}\text { Eats cabbage, cauliflowers, } \\
\text { broccoli. When you see plenty of } \\
\text { butterflies, soon the worms will } \\
\text { come. / It comes through the } \\
\text { window when it is open. }\end{array}$ & A & 11 \\
\hline 146. & 14 & $\begin{array}{l}\text { Tineola biselliella } \\
\text { common clothes } \\
\text { moth }\end{array}$ & moly, molylepke & $\begin{array}{l}\text { Eats your clothing. / The little } \\
\text { moth worms. }\end{array}$ & $\mathrm{H}$ & 96 \\
\hline 147. & 14 & $\begin{array}{l}\text { Ostrinia nubilalis } \\
\text { European corn } \\
\text { borer }\end{array}$ & $\begin{array}{l}\text { málépillangó (maize pillangó), } \\
\text { molylepke }\end{array}$ & $\begin{array}{l}\text { If you are careless and leave old } \\
\text { corn in the silo and put the new } \\
\text { one on top, that one will be two } \\
\text { years old and definitely infested } \\
\text { with it. / Doesn't eat the corn, just } \\
\text { the germ. / When corn is over, half } \\
\text { a handful of dust is left. It is } \\
\text { butterfly droppings. }\end{array}$ & S & 70 \\
\hline 148. & 14 & $\begin{array}{l}\text { Catocala elocata } \\
\text { French red } \\
\text { underwing }\end{array}$ & bagolylepke (owl lepke) & The one with the red back wings. & A & 2 \\
\hline 149. & 14 & $\begin{array}{l}\text { Helicoverpa } \\
\text { armigera } \\
\text { cotton bollworm }\end{array}$ & $\begin{array}{l}\text { bagolylepke (owl lepke), paszuly- } \\
\text { molypillangó (beans } \\
\text { molypillangó) }\end{array}$ & $\begin{array}{l}\text { It goes into the geranium buds } \\
\text { and eats them from inside. / Likes } \\
\text { to attach to trees. And to the } \\
\text { walls, frequently comes in. / When } \\
\text { it comes out of the bean, a hole is } \\
\text { left behind. A little white worm. }\end{array}$ & A & 23 \\
\hline 150. & 14 & $\begin{array}{l}\text { Cossus cossus } \\
\text { goat moth }\end{array}$ & szúlepke (engraver beetle lepke) & $\begin{array}{l}\text { Big brown butterfly. Puts eggs into } \\
\text { the bark. It gets into timber laid a } \\
\text { long time raw with the bark on. } \\
\text { They are almost as big as a grub. } \\
\text { Gnaw out passages like a pencil. }\end{array}$ & S & 5 \\
\hline 151. & 14 & $\begin{array}{l}\text { Saturnia pyri* } \\
\text { giant peacock } \\
\text { moth }\end{array}$ & $\begin{array}{l}\text { boszorkánypille (witch pille), } \\
\text { halállepke (death lepke), } \\
\text { szemeslepke (eyed lepke) }\end{array}$ & $\begin{array}{l}\text { They are big, appear late in the } \\
\text { evening when you put the lights } \\
\text { on. / Superstitious folks would nail } \\
\text { it above the door. }\end{array}$ & $\mathrm{O}$ & 16 \\
\hline 152. & 14 & $\begin{array}{l}\text { Iphiclides podalirius* } \\
\text { scarce swallowtail }\end{array}$ & $\begin{array}{l}\text { fecskefarkú lepke (swallow tail } \\
\text { lepke), fecskeszárnyú pillangó } \\
\text { (swallow winged pillangó) }\end{array}$ & $\begin{array}{l}\text { The same (as Papilio machaon), } \\
\text { only with a different colour and } \\
\text { patterns. / The wings have forked } \\
\text { ends. }\end{array}$ & G & 14 \\
\hline 153. & 14 & $\begin{array}{l}\text { Papilio machaon* } \\
\text { common } \\
\text { swallowtail }\end{array}$ & $\begin{array}{l}\text { fecskefarkú lepke (swallow tail } \\
\text { lepke), fecskeszárnyú pillangó } \\
\text { (swallow winged pillangó) }\end{array}$ & See above & G & 14 \\
\hline 154. & 14 & $\begin{array}{l}\text { Lymantria dispar } \\
\text { Gypsy moth }\end{array}$ & $\begin{array}{l}\text { gyapjaspillangó (woolly } \\
\text { pillangó), gyapjaslepke (woolly } \\
\text { lepke) }\end{array}$ & $\begin{array}{l}\text { Worm, eats away the leaves of a } \\
\text { tree. One year it grazed off all } \\
\text { leaves by the first of July. Within } \\
\text { less than one and half months it } \\
\text { was green again because what } \\
\text { nature can spoil, can make it right } \\
\text { again. }\end{array}$ & $\mathrm{F}$ & 56 \\
\hline 155. & 14 & $\begin{array}{l}\text { Bombyx mori } \\
\text { domesticated } \\
\text { silkmoth }\end{array}$ & $\begin{array}{l}\text { selyemhernyó (silk hernyó), } \\
\text { selyemlepke (silk lepke) }\end{array}$ & $\begin{array}{l}\text { They had to go each day, picked } \\
\text { the mulberry tree leaves for them. }\end{array}$ & $\mathrm{H}$ & 4 \\
\hline 156. & 15 & $\begin{array}{l}\text { Aedes spp. e.g. } \\
\text { Aedes vexans } \\
\text { mosquito species }\end{array}$ & szúnyog, bagline & $\begin{array}{l}\text { Can cause inconvenience. / Has } \\
\text { the impertinence to enter the } \\
\text { house. / Little, thin, but if sucks } \\
\text { itself full of blood, the bite would } \\
\text { itch, you can't help it. / When it's } \\
\text { rainy, there is plenty, and evenings } \\
\text { in marshy places. / I got the }\end{array}$ & $\mathrm{H}$ & 100 \\
\hline
\end{tabular}


Table 3 Data base of invertebrate folk knowledge among Hungarians (Continued)

\begin{tabular}{|c|c|c|c|c|c|c|}
\hline & & & & $\begin{array}{l}\text { malaria once from a mosquito } \\
\text { bite. I was a little girl. }\end{array}$ & & \\
\hline 157. & 6 & $\begin{array}{l}\text { Ceratopogonidae } \\
\text { e.g. Culicoides } \\
\text { imicola } \\
\text { biting midges }\end{array}$ & báglinc, muslinca & $\begin{array}{l}\text { Tiny beasts, like a bigger poppy } \\
\text { seed. I It was black, but it is also } \\
\text { bad. I There was plenty on the } \\
\text { meadow in floods. / Harder and } \\
\text { smaller than the mosquito. I If you } \\
\text { smear it over with vinegar, itching } \\
\text { will go away. }\end{array}$ & $\mathrm{F}$ & 14 \\
\hline 158. & 14 & $\begin{array}{l}\text { Psychodidae e.g. } \\
\text { Clogmia } \\
\text { albipunctata } \\
\text { moth flies }\end{array}$ & no name & $\begin{array}{l}\text { There is a million in the bath. Both } \\
\text { summer and winter. }\end{array}$ & $\mathrm{H}$ & 13 \\
\hline 159. & 6 & $\begin{array}{l}\text { Drosophila spp. e.g. } \\
\text { Drosophila } \\
\text { melanogaster } \\
\text { fruit flies }\end{array}$ & muslica, muska, baglinc & $\begin{array}{l}\text { There are millions. When the wine } \\
\text { works. / Doesn't go into the must. }\end{array}$ & $\mathrm{H}$ & 100 \\
\hline 160. & 15 & $\begin{array}{l}\text { Tipula spp. e.g. } \\
\text { Tipula maxima } \\
\text { crane flies }\end{array}$ & $\begin{array}{l}\text { szúnyog, szúnyogkirály (king } \\
\text { szúnyog), árvaszúnyog (orphan } \\
\text { szúnyog), apatini szúnyog, } \\
\text { óriásszúnyog (giant szúnyog) }\end{array}$ & $\begin{array}{l}\text { It does not bite, only flies around } \\
\text { in the house. / The long legged } \\
\text { one does not creep on you. / We } \\
\text { stroke the mosquito king to death, } \\
\text { there will be no mosquitoes now - } \\
\text { this is how we said. }\end{array}$ & $\mathrm{H}$ & 60 \\
\hline 161. & 5 & $\begin{array}{l}\text { Tabanus bovinus } \\
\text { pale giant horse-fly }\end{array}$ & bögöly, pécsik & $\begin{array}{l}\text { It's got streaked eyes. / Bites you as } \\
\text { well, but cows get them in lots! I } \\
\text { When you sweat, it will attack you. }\end{array}$ & $P$ & 11 \\
\hline 162. & 5 & $\begin{array}{l}\text { Oestrus ovis } \\
\text { sheep bot fly }\end{array}$ & bogár & $\begin{array}{l}\text { A fly lays eggs in the nostril of the } \\
\text { sheep. When developed, the sheep } \\
\text { would blow it out. We would } \\
\text { always see two or three in the } \\
\text { fodder trough. }\end{array}$ & $P$ & 4 \\
\hline 163. & 5 & $\begin{array}{l}\text { Gastrophilus } \\
\text { intestinatus } \\
\text { horse bot fly }\end{array}$ & lóbögöly (horse bögöly) & - & $P$ & 2 \\
\hline 164. & 5 & $\begin{array}{l}\text { Haematopota spp. } \\
\text { e.g. Haematopota } \\
\text { pluvialis } \\
\text { clegs (horsefly } \\
\text { species) }\end{array}$ & $\begin{array}{l}\text { pécsik, pécsiklégy, bögöly, lólégy } \\
\text { (horse légy), bogaraztató légy } \\
\text { (make-jump légy) }\end{array}$ & $\begin{array}{l}\text { It bites the cows in summer. Horses } \\
\text { even more. Greyish. Bite more } \\
\text { before rain. / From beginning, mid- } \\
\text { July up to mid-August is the sea- } \\
\text { son when they attack livestock in } \\
\text { big numbers. }\end{array}$ & $P$ & 83 \\
\hline 165. & 5 & $\begin{array}{l}\text { Hypoderma bovis } \\
\text { warble fly }\end{array}$ & $\begin{array}{l}\text { iméj, böge, dongólégy (buzzing } \\
\text { légy), zigarzóbogár }\end{array}$ & $\begin{array}{l}\text { Winters under the skin of wild } \\
\text { game. Long ago they were there } \\
\text { under the skin of the cattle, } \\
\text { livestock. / We would press them } \\
\text { out from the back of the cows. / } \\
\text { When it started to buzz, it rounded } \\
\text { up livestock like a dog. }\end{array}$ & $P$ & 77 \\
\hline 166. & 5 & $\begin{array}{l}\text { Lucilia spp. e.g. } \\
\text { Lucilia caesar } \\
\text { blow flies }\end{array}$ & $\begin{array}{l}\text { döglégy (carcass légy), } \\
\text { beköpőlégy (spiting légy) }\end{array}$ & $\begin{array}{l}\text { Shiny, mostly on droppings. / You } \\
\text { must not have meat left exposed } \\
\text { because flies would have spat on } \\
\text { it. }\end{array}$ & $S$ & 73 \\
\hline 167. & 5 & $\begin{array}{l}\text { Calliphora vicina } \\
\text { bluebottle blowfly }\end{array}$ & $\begin{array}{l}\text { döglégy (carcass légy), köpőlégy } \\
\text { (spiting légy) }\end{array}$ & $\begin{array}{l}\text { Spit on meat (=lays eggs on } \\
\text { meat). / Bluish ones are bigger } \\
\text { than the green ones. }\end{array}$ & S & 21 \\
\hline 168. & 5 & $\begin{array}{l}\text { Fannia canicularis } \\
\text { lesser house fly }\end{array}$ & $\begin{array}{l}\text { légy, kutyalégy (dog légy), } \\
\text { istállólégy (stable légy) }\end{array}$ & $\begin{array}{l}\text { Little black. Not so noisy like an } \\
\text { ordinary fly. And keeps on flying } \\
\text { around the lamp. }\end{array}$ & $\mathrm{H}$ & 15 \\
\hline 169. & 5 & $\begin{array}{l}\text { Musca domestica } \\
\text { housefly }\end{array}$ & $\begin{array}{l}\text { légy, házi légy (house légy), } \\
\text { pusztuljka (little perish) }\end{array}$ & $\begin{array}{l}\text { It's not so dangerous which is in } \\
\text { the house. / When flies bite, it will } \\
\text { rain, they say. }\end{array}$ & $\mathrm{H}$ & 100 \\
\hline 170. & 5 & $\begin{array}{l}\text { Stomoxys calcitrans } \\
\text { stable fly }\end{array}$ & légy & $\begin{array}{l}\text { Smaller with a pointed nose. They } \\
\text { would bite my leg. }\end{array}$ & S & 2 \\
\hline
\end{tabular}


Table 3 Data base of invertebrate folk knowledge among Hungarians (Continued)

\begin{tabular}{|c|c|c|c|c|c|c|}
\hline 171. & 5 & $\begin{array}{l}\text { Haematobia irritans } \\
\text { horn fly }\end{array}$ & óli légy (pen légy), légy & $\begin{array}{l}\text { That one is longer nosed, but } \\
\text { smaller, bites so hard that you } \\
\text { jump. }\end{array}$ & $S$ & 7 \\
\hline 172. & 5 & $\begin{array}{l}\text { Sarcophaga } \\
\text { carnaria } \\
\text { common flesh fly }\end{array}$ & $\begin{array}{l}\text { nyűszaró (maggot shit), } \\
\text { dongólégy (buzzing légy), } \\
\text { köpőlégy (spiting légy) }\end{array}$ & $\begin{array}{l}\text { Big blacks also spat on the meat. } \\
\text { And then the maggots gnawed } \\
\text { out the meat. / Big and humming, } \\
\text { flies quickly. / Maybe this lays most } \\
\text { because it is directly full with those } \\
\text { tiny worms. You can see it when } \\
\text { you squash it. }\end{array}$ & $S$ & 66 \\
\hline 173. & 5 & $\begin{array}{l}\text { Simulium spp. e.g. } \\
\text { Simulium } \\
\text { colombaschense } \\
\text { black flies }\end{array}$ & $\begin{array}{l}\text { kolombácsi (originated from } \\
\text { Kolumbács) }\end{array}$ & $\begin{array}{l}\text { This attacks the livestock, cows } \\
\text { intensively. They say, it may } \\
\text { happen that the cow will perish } \\
\text { when bitten. / This fly was here in } \\
1938 \text { and it was drummed out } \\
\text { that everybody should take care } \\
\text { and not go to the meadows too } \\
\text { frequently, because you will get } \\
\text { bitten. / We put (dry) manure in a } \\
\text { pot and walked around the } \\
\text { grandma so she could hoe and } \\
\text { this fly did not hurt her. We made } \\
\text { smoke of it. }\end{array}$ & S & 25 \\
\hline 174. & 9 & $\begin{array}{l}\text { Melophagus ovinus } \\
\text { sheep ked }\end{array}$ & $\begin{array}{l}\text { juhkullancs (sheep kullancs), } \\
\text { kullancs }\end{array}$ & $\begin{array}{l}\text { Stays in sheep. Flat. / Gnawed the } \\
\text { wool. }\end{array}$ & $P$ & 4 \\
\hline 175. & 5 & $\begin{array}{l}\text { Hippobosca } \\
\text { longipennis } \\
\text { dog fly }\end{array}$ & kutyalégy (dog légy) & $\begin{array}{l}\text { Sticks on the dog, you can hardly } \\
\text { get rid of it. }\end{array}$ & $P$ & 2 \\
\hline 176. & 10 & $\begin{array}{l}\text { Rhagoletis cerasi s.l. } \\
\text { cherry fruit fly }\end{array}$ & kukac & $\begin{array}{l}\text { My mother would say we should } \\
\text { not look for it, because the tiny } \\
\text { worm was created in it. Well, it } \\
\text { was, because it was put in it } \\
\text { during blossoming. }\end{array}$ & $\mathrm{O}$ & 94 \\
\hline 177. & 10 & $\begin{array}{l}\text { Rhagoletis } \\
\text { pomonella } \\
\text { apple maggot }\end{array}$ & almalégy (apple légy) & $\begin{array}{l}\text { In fact not all are the same, this } \\
\text { one gnaws at the apples only. }\end{array}$ & O & 10 \\
\hline 178. & 10 & $\begin{array}{l}\text { Psila rosae } \\
\text { carrot fly }\end{array}$ & fireg, murokfireg (carrot worm) & Little soft white worm. & S & 6 \\
\hline 179. & 10 & $\begin{array}{l}\text { Delia radicum } \\
\text { cabbage fly }\end{array}$ & káposztaféreg (cabbage féreg) & $\begin{array}{l}\text { Gnaws on cabbage leaves, but } \\
\text { what it will become, we do not } \\
\text { know. }\end{array}$ & A & 12 \\
\hline 180. & 9 & $\begin{array}{l}\text { Braula coeca } \\
\text { bee louse }\end{array}$ & méhkullancs (bee kullancs) & $\begin{array}{l}\text { A tiny animal. / You get them on } \\
\text { bees, this red one. It kills the bees. I } \\
\text { When you neglect their } \\
\text { management, it's when it comes. }\end{array}$ & $P$ & 6 \\
\hline 181. & 9 & $\begin{array}{l}\text { Aphididae (green) } \\
\text { e.g. Aphis pomi } \\
\text { green colored } \\
\text { aphid species }\end{array}$ & $\begin{array}{l}\text { levéltetú (leaf tetû́), tetü, ződtetyű } \\
\text { (green tetü) }\end{array}$ & $\begin{array}{l}\text { That one is green. It does not } \\
\text { hatch (does not lay eggs), it litters } \\
\text { (gives birth). The ladybird eats } \\
\text { them. The dropping is sweet. Ants } \\
\text { would climb the tree to feed on it. } \\
\text { I It is under the leaves. It sucks and } \\
\text { the leaf goes dry. If there are many } \\
\text { on the peach tree, wasps would } \\
\text { also gather. }\end{array}$ & O & 100 \\
\hline 182. & 9 & $\begin{array}{l}\text { Myzus cerasi } \\
\text { black cherry aphid }\end{array}$ & $\begin{array}{l}\text { fekete levéltetü (black leaf tetú), } \\
\text { levéltetű (leaftetú) }\end{array}$ & $\begin{array}{l}\text { The black leaf louse likes cherries } \\
\text { better. / The edges of the leaf curl } \\
\text { up because it sucks on it. }\end{array}$ & O & 16 \\
\hline 183. & 9 & $\begin{array}{l}\text { Dysaphis } \\
\text { plantaginea } \\
\text { rosy apple aphid }\end{array}$ & szürketetü (grey tetú), tetü & $\begin{array}{l}\text { Tiny and grey. Water with } \\
\text { bordeaux mixture, it will be killed } \\
\text { off. A little weak something. The } \\
\text { leaf would curl up. }\end{array}$ & O & 21 \\
\hline 184. & 9 & Planococcus citri & gyapjastetű (woolly tetű) & & $u$ & 4 \\
\hline
\end{tabular}


Table 3 Data base of invertebrate folk knowledge among Hungarians (Continued)

\begin{tabular}{|c|c|c|c|c|c|}
\hline & citrus mealybug & & $\begin{array}{l}\text { This one is like if it was mouldy. It } \\
\text { is mostly at the stem of leaves. } \\
\text { This does not fly, where does it } \\
\text { generate, where does it come from, } \\
\text { I do not know. }\end{array}$ & & \\
\hline 185. 9 & $\begin{array}{l}\text { Aleyrodina e.g. } \\
\text { Aleyrodes proletella } \\
\text { whiteflies }\end{array}$ & $\begin{array}{l}\text { hamufireg (ash fíreg), tetü, } \\
\text { pillangó }\end{array}$ & $\begin{array}{l}\text { The twig would go entirely white. I } \\
\text { Those whites are the butterflies. It } \\
\text { does harm to the grapevine. } \\
\text { Gnaws at it when in blossom. }\end{array}$ & A & 20 \\
\hline 186. 9 & $\begin{array}{l}\text { Pulex irritans } \\
\text { human flea }\end{array}$ & bolha & $\begin{array}{l}\text { Jumps, tiny and black. I We would } \\
\text { put walnut tree leaves in the neck } \\
\text { to the shirt, so they did not hurt } \\
\text { us. }\end{array}$ & P & 100 \\
\hline 187. 9 & $\begin{array}{l}\text { Ctenocephalides } \\
\text { canis } \\
\text { dog flea }\end{array}$ & bolha, rókabolha (fox bolha) & $\begin{array}{l}\text { There are many fleas in the dog } \\
\text { which also attacks man. / That } \\
\text { one would bite you as well, but it } \\
\text { does not stay, does not like it so } \\
\text { much. }\end{array}$ & $P$ & 6 \\
\hline 188. 9 & $\begin{array}{l}\text { Viteus vitifolii } \\
\text { vine louse }\end{array}$ & filoxera & - & $\mathrm{O}$ & 2 \\
\hline 189. 9 & $\begin{array}{l}\text { Coccoidea e.g. } \\
\text { Quadraspidiotus } \\
\text { perniciosus } \\
\text { scale insect }\end{array}$ & pajzstetű (shield tetû) & $\begin{array}{l}\text { We did not have it when I was a } \\
\text { child. / It's like an armour on the } \\
\text { back. Eats away the leaves but the } \\
\text { stems even more. / That one is } \\
\text { here on the plum tree. Sometimes } \\
\text { it's not any more only the house. It } \\
\text { has left it. }\end{array}$ & $\mathrm{O}$ & 7 \\
\hline 190. 9 & $\begin{array}{l}\text { Eriosoma lanigerum } \\
\text { woolly apple aphid }\end{array}$ & vértetű (blood tetű) & - & $\mathrm{O}$ & 4 \\
\hline 191. 9 & $\begin{array}{l}\text { Pediculus humanus } \\
\text { capitis } \\
\text { head louse }\end{array}$ & $\begin{array}{l}\text { tetü, fejtetú (head tetú), hajtetü } \\
\text { (hair tetü), serke }\end{array}$ & $\begin{array}{l}\text { Climbs on you, on your head. I It's } \\
\text { not a shame to get it, only to keep } \\
\text { it. / It was healed at the house. We } \\
\text { mixed oil, spirit and petrol and } \\
\text { smeared with it. We still have it. It's } \\
\text { because untidiness. }\end{array}$ & $P$ & 100 \\
\hline 192. 9 & $\begin{array}{l}\text { Menacanthus } \\
\text { stramineus } \\
\text { chicken body louse }\end{array}$ & tyúktetü (hen tetü), tetü & $\begin{array}{l}\text { It does not stick to man. / It was } \\
\text { controlled by onion oil. You must } \\
\text { roast onions and smear it. / Pig } \\
\text { fat, small red peppers were put in } \\
\text { it, and [Sambucus ebulus] in the } \\
\text { pen. }\end{array}$ & $P$ & 91 \\
\hline 193. 9 & $\begin{array}{l}\text { Haematopinus suis } \\
\text { hog louse }\end{array}$ & tetü, disznótetű (pig tetű), sörte & $\begin{array}{l}\text { It's greater than the other lice, but } \\
\text { does not live of man. }\end{array}$ & $P$ & 29 \\
\hline 194. 9 & $\begin{array}{l}\text { Bovicola bovis } \\
\text { red louse }\end{array}$ & tetyü & $\begin{array}{l}\text { Cattle would be smeared over with } \\
\text { tobacco juice. There is none any } \\
\text { more. }\end{array}$ & P & 20 \\
\hline 195. 9 & $\begin{array}{l}\text { Pediculus humanus } \\
\text { humanus } \\
\text { body louse }\end{array}$ & ruhatetü (cloth tetü), tetü & $\begin{array}{l}\text { Which lives in the cloth, would not } \\
\text { go on your head. / That one is } \\
\text { white. }\end{array}$ & $P$ & 91 \\
\hline 196. 9 & $\begin{array}{l}\text { Pthirus pubis } \\
\text { crab louse }\end{array}$ & lapostetű (flat tetű) & $\begin{array}{l}\text { They say it's on your loin only. } \\
\text { Nowhere else. }\end{array}$ & P & 8 \\
\hline 197. 9 & $\begin{array}{l}\text { Cimex lectularius } \\
\text { bed bug }\end{array}$ & poloska & $\begin{array}{l}\text { You had to sleep with the lights } \\
\text { on because in the dark the plant } \\
\text { bug would come out. / They } \\
\text { occurred only during the war. }\end{array}$ & P & 27 \\
\hline 198. 6 & $\begin{array}{l}\text { Blatta orientalis } \\
\text { oriental cockroach }\end{array}$ & $\begin{array}{l}\text { csótány, svábogár (Swabian } \\
\text { bogár) }\end{array}$ & $\begin{array}{l}\text { In the blocks of flats. Totally black } \\
\text { beetle, a larger one. / They creep } \\
\text { under the cupboards. / If you put } \\
\text { on the light, it will disappear. }\end{array}$ & $\mathrm{H}$ & 23 \\
\hline 199. 6 & $\begin{array}{l}\text { Blattella germanica } \\
\text { German cockroach }\end{array}$ & $\begin{array}{l}\text { csótány, svábogár (Swabian } \\
\text { bogár) }\end{array}$ & $\begin{array}{l}\text { They like to stay in neglected, } \\
\text { abandoned kitchens. }\end{array}$ & $\mathrm{H}$ & 12 \\
\hline
\end{tabular}


Table 3 Data base of invertebrate folk knowledge among Hungarians (Continued)

\begin{tabular}{|c|c|c|c|c|c|c|}
\hline 200. & 6 & $\begin{array}{l}\text { Dermaptera e.g. } \\
\text { Forficula auricularia } \\
\text { earwigs }\end{array}$ & fülbemászó (ear crawler) & $\begin{array}{l}\text { Climbs in your ear and drills it. A } \\
\text { bad lot. It has a little dart. / Some } \\
\text { went deaf. / Runs away quickly, } \\
\text { thin and long. / Cloth, coat was } \\
\text { left hung on the tree, this would } \\
\text { enter there. }\end{array}$ & $\mathrm{O}$ & 92 \\
\hline 201. & 7 & $\begin{array}{l}\text { Cicadinae (except } \\
\text { Cicada orni) e.g. } \\
\text { Cicadella viridis } \\
\text { cicadas }\end{array}$ & sáska, szöcske (hopper) & A little bouncing bug. & G & 7 \\
\hline 202. & 7 & $\begin{array}{l}\text { Cicada orni* } \\
\text { bigger cicada } \\
\text { species }\end{array}$ & őszike (little autumn), trücsök & $\begin{array}{l}\text { It is able to sound for hours } \\
\text { (vocalisation). Starts to buzz at } \\
\text { harvest time. It is able to howl for } \\
10 \text { minutes, for } 20 \text { minutes the } \\
\text { same tone. I It's rare in our region, } \\
\text { but there are many of them at the } \\
\text { sea (Adriatic). }\end{array}$ & $\mathrm{O}$ & 7 \\
\hline 203. & 15 & $\begin{array}{l}\text { Cercopidae e.g. } \\
\text { Philaenus spumarius } \\
\text { froghoppers (cicad } \\
\text { species) }\end{array}$ & hab (foam) & $\begin{array}{l}\text { It might be a kind of saliva. / There } \\
\text { are little ash worms in it, that's } \\
\text { why. }\end{array}$ & G & 74 \\
\hline 204. & 6 & $\begin{array}{l}\text { Myrmeleontidae } \\
\text { e.g. Myrmeleon } \\
\text { formicarius } \\
\text { antlions }\end{array}$ & porvaatka (dust mite), bogár & $\begin{array}{l}\text { There is a lot of dust under the } \\
\text { barn, where it is dry, it makes that } \\
\text { nest. But it turns around with such } \\
\text { a speed it would scatter dust on } \\
\text { both sides. / Sparrows pick them } \\
\text { out all. }\end{array}$ & S & 12 \\
\hline 205. & 14 & $\begin{array}{l}\text { Chrysopa spp. e.g. } \\
\text { Chrysopa perla } \\
\text { lacewings }\end{array}$ & $\begin{array}{l}\text { szitakötő (sieve weaver), } \\
\text { aranyszemú fátyolka (gold eyed } \\
\text { veil), lepke }\end{array}$ & $\begin{array}{l}\text { Flutters its wings. / Comes in to } \\
\text { the light. / Very stinky when you } \\
\text { catch it. / Its wings are like a sieve. } \\
\text { There is plenty of them in Fall. }\end{array}$ & $\mathrm{H}$ & 29 \\
\hline 206. & 15 & $\begin{array}{l}\text { Palingenia } \\
\text { longicauda* } \\
\text { Tisa mayfly }\end{array}$ & tiszavirág (Tisza flower), kérész & Short lived. One day and it's over. & W & 18 \\
\hline 207. & 15 & $\begin{array}{l}\text { Odonata e.g. } \\
\text { Sympetrum } \\
\text { sanguineum } \\
\text { red dragonflies }\end{array}$ & $\begin{array}{l}\text { szitakötő (sieve weaver), } \\
\text { vízipillangó (water pillangó), } \\
\text { víziszita (water sieve) }\end{array}$ & $\begin{array}{l}\text { It's got a wing like a sieve. / Flies } \\
\text { above the water and feeds on } \\
\text { mosquitoes. Flies quickly, stops } \\
\text { suddenly and hovers. }\end{array}$ & W & 21 \\
\hline 208. & 15 & $\begin{array}{l}\text { Odonata e.g. Anax } \\
\text { imperator } \\
\text { blue dragonflies }\end{array}$ & $\begin{array}{l}\text { szitakötő (sieve weaver), } \\
\text { vízipillangó (water pillangó), } \\
\text { víziszita (water sieve) }\end{array}$ & See above. & W & 100 \\
\hline
\end{tabular}

Latin equivalent, English scientific name and Hungarian vernacular names of 208 invertebrate taxa with a typical citation for each, main habitat and proportion of informants who knew the taxon. Key places of encounter and habitats are as follows: aquatic, riparian habitat (W); forest (F); grassy, shrubby areas (G); cropland $(A)$; vineyard, orchard $(O)$; surrounding of the house, village, garden $(S)$; on animal/human $(P)$; in the house $(H)$, everywhere $(O)$

\section{Acknowledgements}

We gratefully acknowledge all the people of Szilágyság, Drávaszög and Gömör who patiently and generously shared their knowledge with us: Ambrus Erzsébet, Bordás Eszter, Bordás Lajos, Csíki Andrást, Farnas Annat, Farnas Géza, Fazekas Margit†, Fazekas Mihály, Fazekas Sándor, Kandert János, László Lajos, Nemes Karolina, Ősz Margit, Őz Pál, Posta Eszter, Posta Rozália, Somogyi Lídia, Szabó István, Szabó Pált, Szűcs Klára, Laczkó János, Kovács Sándor, Kettős Dezső, Kettős Jolán, Pataky Andrást, Kristóf Ida, Pajrok János, Dobszai Máriat, Lubascsik Lajost, Bicó Rózsika, Kovács Gyula, Kőgyesi Jánost, Molnár Józseft, Tibor Dezső, Vidra György, Csokonai Margareta, Kelemen Sára, Borkó Pál, Hegedűs Sándor, Karakas Attila, Szarka Irma, Bak Zoltán, Ferenc Mária, Micheli István, Micheli József, Muhi Ferenc, Balajti Béla, Borbély László, Cselényi József, Fábry Zoltán, Forgon Andor, Forgon Györgyné, Kertész László, Miklós Zoltán, Nagy Dezső, Nagy llona, Tóth Kálmánné, Tóth Lászlóné. Thanks to Tórizs István and his family for their help with the field work, to Ulicsni Tiborné for transcribing our recordings, to Varga Zoltán and the Hungarian Institute for Educational Research and Development for granting us permission to use drawings from the book titled 'Állatismeret', and to Szollát György for contacting some of the informants. Thanks to Steve Kane and Béla Borsos for the English translation.

\section{Funding}

The APC is funded in $70 \%$ by the University of Szeged.

\section{Availability of data and materials}

Data are available in appendix.

\section{Authors' contributions}

ZsM and UV have prepared the conception and design of this project. UV undertook the data gathering. ZsM, UV, and IS were involved in analysing data as well as drafting and writing the manuscript. All authors read and approved the final manuscript.

\section{Competing interests}

The authors declare that they have no competing interests.
Consent for publication

Not applicable. 


\section{Ethics approval and consent to participate}

Not applicable, info on FPIC is given in methods.

\section{Author details}

'Department of Ecology, Faculty of Science and Informatics of the University of Szeged, Közép fasor 52, 6726 Szeged, Hungary. ${ }^{2}$ Uppsala Centre for Russian and Eurasian Studies, Uppsala Univerisity, Box 51475120 Uppsala, Sweden. ${ }^{3} \mathrm{MTA}$ Centre for Ecological Research, Institute of Ecology and Botany, 2163 Vácrátót, Hungary.

Received: 2 June 2016 Accepted: 27 September 2016 Published online: 11 October 2016

\section{References}

1. Menzies CR, Butler C. Introduction: Understanding ecological knowledge. In: Menzies CR, editor. Traditional Ecological Knowledge and Natural Resource Management. Lincoln: University of Nebraska Press; 2006. p. 1-17.

2. Berkes F, Colding J, Folke C. Navigating social-ecological systems: building resilience for complexity and change. Cambridge: Cambridge University Press; 2008.

3. Ellen R. The cultural relations of classification: an analysis of Nuaulu animal categories from central Seram, Vol. 91. Cambridge: Cambridge University Press; 2006.

4. Hunn ES. Ethnozoology. Ethnobiology. Hoboken, New Jersey: John Wiley; 2011;83-96.

5. Alves RRN. Relationships between fauna and people and the role of ethnozoology in animal conservation. Ethn Conserv. 2012;1:1-69.

6. Iturralde J, Bordas MIS, Zabala J. Etnoentomología de la Vaquita de San Antón o mariquita (Coccinella septem-punctata) en el País Vasco (Coleoptera: Coccinellidae). Bol. SEA; 2003;253-69.

7. Fridell S, Svanberg I. Däggdjur i svensk folklig tradition. Stockholm: Dialogos; 2007.

8. Fischer-Kowalski M, Weisz H. Society as hybrid between material and symbolic realms: Toward a theoretical framework of society-nature interaction. Advanc Human Ecol. 1999;8:215-52.

9. Nishida AK, Nordi N, Alves RRDN. Mollusc gathering in Northeast Brazil: an ethnoecological approach. Hum Ecol. 2006;34:133-45.

10. Colding J, Folke C. Social taboos:"invisible" systems of local resource management and biological conservation. Ecol Appl. 2001;11:584-600.

11. Primack RB. Essentials of conservation biology, vol. 23. Sunderland: Sinauer Associates; 2006

12. Molnár Z, Gellény K, Margóczi K, Biró M. Landscape ethnoecological knowledge base and management of ecosystem services in a SzékelyHungarian pre-capitalistic village system (Transylvania, Romania). J Ethnobiol Ethnomed. 2015;11:3

13. Davidson-Hunt IJ, Berkes F. Nature and society through the lens of resilience: toward a human-in-ecosystem perspective. In: Berkes F, Colding J, Folke C, editors. Navigating social-ecological systems. Building resilience for complexity and change. Cambridge: Cambridge University Press; 2005. p. 53-82.

14. Gunderson LH. Adaptive dancing: interactions between social resilience and ecological crises. In: Berkes F, Colding J, Folke C, editors. Navigating socialecological systems. Building resilience for complexity and change. Cambridge: Cambridge University Press; 2005. p. 33-52.

15. Diamond L, Bishop KD. Ethno-ornithology of the Ketengban People Indonesian New Guinea. In: Medin DL, Atran S, editors. Folkbiology. Cambridge: The MIT Press; 1999. p. 17-45.

16. Huntington HP. Using traditional ecological knowledge in science: Methods and applications. Ecol Appl. 2000;10:1270-4.

17. Roba HG, Oba G. Community participatory landscape classification and biodiversity assessment and monitoring of grazing lands in northern Kenya. J Environ Manag. 2009;90:673-82.

18. Mapinduzi AL, Oba G, Weladji RB, Colman JE. Use of indigenous ecological knowledge of the Maasai pastoralists for assessing rangeland biodiversity in Tanzania. Afr J Ecol. 2003;41:329-36.

19. Roba HG, Oba G. Efficacy of Integrating Herder Knowledge and Ecological Methods for Monitoring Rangeland Degradation in Northern Kenya. Hum Ecol. 2009;37:587-612.

20. Gadgil M, Olsson P, Berkes F, Folke C, Berkes F, Colding J, Folke C. Exploring the role of local ecological knowledge in ecosystem management: three case studies. In: Navigating social-ecological systems. Cambridge: Cambridge University Press; 2005. p. 189-209.
21. Gilchrist HG, Mallory ML, Merkel F. Can local ecological knowledge contribute to wildlife management? Case studies of migratory birds. Ecol Soc. 2005;10:20-32.

22. Gomez-Baggethun E, Mingorria S, Reyes-Garcia V, Calvet L, Montes C. Traditional Ecological Knowledge Trends in the Transition to a Market Economy: Empirical Study in the Donana Natural Areas. Conserv Biol. 2010;24:721-9.

23. Bonta M. Ethno-ornithology and biological conservation. In: Tideman S, Gosler A, editors. Ethno-ornithology. Birds, indigenous peoples, culture and society. London: Earthscan; 2010. p. 13-29.

24. Lévi-Strauss C. La pensée sauvage. Plon: Paris; 1962. p. 389.

25. Svanberg I, Luczaj L, Pardo-de-Santayana M, Pieroni A. History and current trends of ethnobiological research in Europe. In: Anderson EN, Pearsall D, Hunn E, Turner NJ, editors. Ethnobiology. Hoboken: Wiley-Blackwell; 2011. p. 191-214.

26. Stearns REC. Ethno-conchology: A study of primitive money. Report of the United States National Museum for the year ending June 30, 1887 (Pt. 2 of the Annual Report of the Board of Regents of the Smithsonian Institution for the year ending June 30, 1887.). 1887. p. 297-334.

27. Harshberger JW. Some new ideas. Philadelphia: Philadelphia Evening Telegraph; 1895.

28. Henderson J, Harrington JP. Ethnozoology of the Tewa indians. Smithsonian Institution Bur. Am. Ethnol. Bull., Washington; 1914;56.

29. Bodenheimer FS. Insects as Human Food: A Chapter of the Ecology of Man. New York: Springer; 1951. p. 352.

30. Bentley JW, Rodríguez G. Honduran Folk Entomology. CurrAnthropol. 2001;42:285-301.

31. Krause RJ, Vaccaro I, Aswani S. Challenges in Building Insect Ethnobiological Classifications in Roviana, Solomon Islands. J Ethnobiol. 2010;30:308-20.

32. Gurung AB. Insects-a mistake in God's creation? Tharu farmers' perception and knowledge of insects: A case study of Gobardiha Village Development Committee, Dang-Deukhuri. Nepal Agr Hum Values. 2003:20:337-70.

33. Hemp C. Ethnozoological research on invertebrates on Mt. Kilimanjaro, Tanzania. Ecotropica. 2001;7:139-49.

34. Morris B. Insects and Human Life. New York: Berg; 2004. p. 320

35. Pawley A. On the classification of marine animals in Wayan. Science of Pacific Island Peoples. 1994;3:87-107.

36. Svanberg I. Human usage of mermaid's glove sponge (Isodictya palmata) on the Faroes. J Mar Biol Assoc UK. 2007:87:1773-5.

37. Groesbeck AS, Rowell K, Lepofsky D, Salomon AK. Ancient clam gardens increased shellfish production: Adaptive strategies from the past can inform food security today. PLoS One. 2014:9:e91235.

38. Nordi N, Nishida AK, Alves RR. Effectiveness of two gathering techniques for Ucides cordatus in Northeast Brazil: implications for the sustainability of mangrove ecosystems. Hum Ecol. 2009;37:121-7.

39. Alves RRN, Souto WMS. Ethnozoology: A Brief Introduction. Ethnobiol Conserv. 2015:4:1-13.

40. Kato D, Gopi GV. Ethnozoology of Galo tribe with special reference to edible insects in Arunachal Pradesh. Ind J Tradit Knowledge. 2009:8:81-3.

41. Neto E. Bird-spiders (Arachnida, Mygalomorphae) as perceived by the inhabitants of the village of Pedra Branca, Bahia State, Brazil. J Ethnobio Ethnomed. 2006:2:50

42. Chao JT, Fan YB, Yeh WC, Chen YM. The" Sacred Butterfly" in Alishan. Chin J Entomol. 1993;13:385-9.

43. Strindberg A. Svenska folket i helg och söcken, i krig och i fred, hemma och ute eller Ett tusen år af svenska bildningens och sedernas historia. 1. Stockholm: Fritze; 1882.

44. Marian SF. Insectele în limba: credințele, si obiceiurile Românilor. Studiu folkloristic (The insects in the language, beliefs and customs of Romanians. A study in folklore). Inst de Arte Grafice "Carol Göbl". 1903;14:595.

45. Herman O. A magyar pásztorok nyelvkincse: a magyarok nagy ösfoglalkozása. Budapest: Királyi Magyar Természettudományi Társulat; 1914.

46. Wiklund KB. Lapska namn på ren-oestriderna och deras larver. Le Monde Oriental. 1916:10:183-91.

47. Wiggen G. Zoologisk nomenklatur och folketradisjonelle dyrenemningar: ei påminning om etnozoologi som møtespunkt for natur- og kulturutdanning med døme frå limnofaunaen og andre virvellause dyr. Namn og nemne 2008;25:11-48.

48. Zagrobelny M, Dreon AL, Gomiero T, Marcazzan GL, Glaring MA, Møller BL, Paoletti MG. Toxic moths: sources of a truly safe delicacy. J Ethnobiol. 2009;29:64-76.

49. Durst PB, Johnson DV, Leslie RN, Shono K. Forest insects as food: humans bite back. Bangkok: RAP publication; 2010. 
50. Duhart F. Caracoles y sociedades en Europa desde la antigüedad: reflexiones etnozoológicas. Studium: Revista de humanidades. 2009;15:115-39.

51. Svanberg I. Black slugs (Arion ater) as grease: a case study of technical use of gastropods in pre-industrial Sweden. J Ethnobiol. 2006;26:299-309.

52. Vallejo JR, González JA. The medicinal use of leeches in contemporary Spain: between science and tradition. Acta Medico-Historica Adriatica. 2015;13:131-58.

53. Swahn J-Ö. The cultural history of crayfish. Bull Fr Peche Piscic. 2004;372-373:243-51.

54. Percino-Daniel N, Buckley D, García-París M. Pharmacological properties of blister beetles (Coleoptera: Meloidae) promoted their integration into the cultural heritage of native rural Spain as inferred by vernacular names diversity, traditions, and mitochondrial DNA. J Ethnopharmacol. 2013;147:570-83.

55. Vallejo JR, González JA. The use of the head louse as a remedy for jaundice in Spanish folk medicine: an overview. J Ethnobiol Ethnomed. 2013;9:52.

56. Anderson M. Sami children and traditional knowledge. In: Svanberg I, Tunon $\mathrm{H}$, editors. Ecological knowledge in the North. Studies in Ethnobiology. Uppsala: Swedish Biodiversity Centre; 2000. p. 55-66.

57. Svanberg I. Humlehonung, korstroll och ålamask: etnobiologiska essäer om evertebrater i Norden och Estland. Uppsala: Uppsala University; 2006. p. 84.

58. Sõukand R, Kalle R, Svanberg I. Uninvited guests: Traditional insect repellents in Estonia used against the clothes moth Tineola bisselliella, human flea Pulex irritons and bedbug Cimex lectularius. J Insect Sci. 2010;10:150.

59. Seidel C, Reinhardt K. Bugging forecast: unknown, disliked, occasionally intimate Bed bugs in Germany meet unprepared people. PLoS One. 2013;8:e51083.

60. Rolland E. Faune popularie de la France, 15 volumes. Maisonneuve, Paris; 1877-1915.

61. Gub J. Erdő-mező állatai a Sóvidéken. Korond: Firtos Művelődési Egylet; 1996.

62. Kovács A. Járok-kelek gyöngyharmaton... növény- és állatnevek a FelsőSzigetköz tájnyelvében (Local names of flora and fauna in Felsö-Szigetköz). Mosonmagyaróvári Helytört. Füz; 1987;6:1-110.

63. Kicsi SA. A fák, a kakukk és a rovarok. Budapest: Cédrus Múvészeti Alapítvány - Napkút Kiadó; 2015.

64. Bihari-Horváth L. Szarvaskő "etnomalakológiája" - Az éti csiga gyűjtögetése és fogyasztása egy Heves megyei lokális közösségben. Az egri Dobó István Vármúzeum Évkönyve. Eger. 2011;47:309-26.

65. Hegyi I. A népi erdőkiélés történeti formái. Budapest: Akadémiai Kiadó; 1978.

66. Bartholy J, Bozó L. Magyarország éghajlati atlasza. Budapest: Országos Meteorológiai Szolgálat; 2003.

67. Varga Z. Biogeographical outline of the invertebrate fauna of the Aggtelek Karst and surrounding areas. In: Research in Aggtelek National Park and Biospherre Reserve. Aggtelek: ANP Directorate; 1997. p. 87-94

68. Kutasi C. A Bakony rovarvilága. Zirc: Bakonyi Természettudományi Múzeum; 2002.

69. Răescu CS, Dumbravă-Dodoacă M, Petrovici M. Macrozoobenthic community structure and dynamics in Cerna River (western Romania). AACL Bioflux. 2011;4:79-87.

70. Erőss ZP. A malaco-faunistical study of Salaj county/Szilágyság, Romania with taxonomical notes. Studia Universitatis Vasile Goldis Seria Stiintele Vietii (Life Sciences Series). 2015. p. 25.

71. Berlin B. Ethnobiological classification. Principles of categorization of plants and animals in traditional societies. Princeton: Princeton University Press; 1992.

72. Ulicsni V, Svanberg I, Molnár Z. Folk knowledge of non-domestic mammals among ethnic Hungarians in North-Western Romania. North-West J Zool. 2013;9:383-98

73. Wepukhulu DM. Bukusu Ethnozoology (Invertebrates) - II. Kenya: University of Kenya: Mombasa; 1992; p 17. https://www.scribd.com/collections/ 2316838/Bukusu. Accessed 7 Oct 2016.

74. Avar A. A természet és az állatok a hagyományos mongol gondolkodásban. (Nature and animals in traditional Mongolian thinking.) PhD Thesis. Budapest: Eötvös Loránd Tudományegyetem Bölcsészettudományi Kar; 2012.

75. Molnár Z. Traditional ecological knowledge of herders on the flora and vegetation of the Hortobágy. Debrecen: Hortobágy Természetvédelmi Közalapítvány; 2012.

76. Babai D, Molnár Á, Molnár Z. Traditional ecological knowledge and land use in Gyimes (Eastern Carpathians). Budapest-Vácrátót: MTA BTK Néprajztudományi Intézet és MTA Ökológiai Kutatóközpont Botanikai és Ökológiai Intézet; 2014.

77. Hunn ES, Selam J. Nch'i-wana," the big river": Mid-Columbia Indians and their land. Seattle: University of Washington Press; 1991.
78. Hunn ES. Size as limiting the recognition of biodiversity in folkbiological classifications: One of four factors governing the cultural recognition of biological taxa. In: Medin DL, Atran S, editors. Folkbiology. Cambridge: MIT Press; 1999. p. 47-69.

79. Ramos-Elorduy J, Moreno JM, Vázquez Al, Landero I, Oliva-Rivera H, Camacho VH. Edible Lepidoptera in Mexico: Geographic distribution, ethnicity, economic and nutritional importance for rural people. J Ethnobiol Ethnomed. 2011;7:1.

80. Malaisse F, Latham P. Human consumption of Lepidoptera in Africa: an updated chronological list of references (370 quoted!) with their ethnozoological analysis. Geo-Eco-Trop. 2014;38:339-72.

81. Fleck DW, Voss RS, Simmons NB. Underdifferentiated taxa and sublexical categorization: an example from Matses classification of bats. J Ethnobiol. 2002;22:61-102.

82. Berlin B, Boster JS, O'Neill JP. The perceptual bases of ethnobiological classification: evidence from Aguaruna Jívaróo ornithology. J Ethnobiol. 1981;1:95-108.

83. Molnár Z. Classification of pasture habitats by Hungarian herders in a steppe landscape (Hungary). J Ethnobiol Ethnomed. 2012;8:28.

84. Jolsvay A, Steinmann H, Szily E. A magyar állatvilág szótára. Budapest: Natura Kiadó; 1977.

85. Babai D. Traditional ecological knowledge in the mirror of ethnozoology the local knowledge of Vertebrates in the Gyimes region (Eastern Carpathians, Romania). MSc Thesis. Pécs: Pécsi Tudományegyetem Bölcsészettudományi Kar Néprajz és Kulturális Antropológia Tanszék; 2011.

86. Brown $\mathrm{CH}$. Language and living things: Uniformities in folk classification and naming. New Brunswick: Rutgers University Press; 1984.

87. Pieroni A. Medicinal plants and food medicines in the folk traditions of the upper Lucca Province, Italy. J Ethnopharmacol. 2000;70:235-73.

88. Luczaj L, Köhler P, Pirożnikow E, Graniszewska M, Pieroni A, Gervasi T. Wild edible plants of Belarus: from Rostafiński's questionnaire of 1883 to the present. JEthnobiol Ethnomed. 2013;9:21.

89. Gómez B, Castro A, Jungans C, Montoya LR, Villalobos FJ. Ethnoecology of white grubs (Coleoptera: Melolonthidae) among the Tzeltal Maya of Chiapas. J Ethnobiol. 2000;20:43-59.

90. Ramos-Elorduy J. Threatened edible insects in Hidalgo, Mexico and some measures to preserve them. J Ethnobiol Ethnomed. 2006;2:51.

91. Neto, Eraldo Medeiros Costa, and Josué Marques Pacheco. Utilização medicinal de insetos no povoado de Pedra Branca, Santa Terezinha, Bahia, Brasil. Biotemas 18.1 (2005): 113-133.

92. Paoletti MG, Buscardo E, Dufour DL. Edible invertebrates among Amazonian Indians: a critical review of disappearing knowledge. Environment. Dev Sustainability. 2000;2:195-225.

93. Łuczaj Ł. Podręcznik robakożercy czyli jadalne bezkręgowce Środkowej Europy. Krosno: Wydawnictwo Chemigrafia; 2005.

94. Gulyás S, Sümegi P. Farming and/or foraging? New environmental data to the life and economic transformation of Late Neolithic tell communities (Tisza Culture) in SE Hungary. J Archaeol Sci. 2011;38:3323-39.

95. Meyer-Rochow VB. Ethno-entomological observations from North Korea (officially known as the "Democratic People's Republic of Korea"). J Ethnobiol Ethnomed. 2013;9:7.

96. Tidemann S, Gosler A. Ethno-Ornithology: birds, indigenous peoples, culture and society. London: Earthscan; 2010.

97. Berkes F. Sacred ecology. New York: Routledge; 2012.

98. Nelson RK. Make prayers to the raven. A Koyukon view of the northern forest. Chicago: University of Chicago Press; 1982.

99. Turner N. The earth's blanket: traditional teachings for sustainable living. Vancouver: D \& M Publishers; 2008. 